\title{
Description of five new and six known species of the genus Basirotyleptus Jairajpuri, 1964 (Nematoda: Dorylaimida: Tylencholaimoidea) from the Western Ghats, India
}

\author{
Md Niraul ISLAM ${ }^{\circledR 1, *} \&$ Wasim AHMAD ${ }^{2}$ \\ ${ }^{1,2}$ Nematode Biodiversity Research Lab, Department of Zoology, \\ Aligarh Muslim University, Aligarh- 202002, India. \\ *Corresponding author: mnislam15@gmail.com \\ 2Email: ahmadwasim57@gmail.com \\ ${ }^{1}$ urn:Isid:zoobank.org:author:A202F47B-7E49-43AE-A2EF-988E7E891AA9 \\ ${ }^{2}$ urn:lsid:zoobank.org:author:4A070AF3-8976-49F8-BBC1-497F1B3FB354
}

\begin{abstract}
Five new and six known species belonging to the genus Basirotyleptus collected from the Western Ghats, India, are described and illustrated. Basirotyleptus conicaudatus $\mathrm{sp}$. nov. is characterized by having $0.42-0.44 \mathrm{~mm}$ long body; odontostyle $9.5-10.0 \mu \mathrm{m}$, odontophore $11.5-12.0 \mu \mathrm{m}$; pharyngeal bulb pear-shaped, $14-15 \%$ of total neck length; female genital system mono-opisthodelphic; tail conoid with acute terminus. Basirotyleptus constrictus sp. nov. is characterized by having 0.38-0.49 mm long body; perioral disc distinct; odontostyle 9-10 $\mu \mathrm{m}$, odontophore 14-15 $\mu \mathrm{m}$; pharyngeal bulb pear-shaped, $15-17 \%$ of total neck length; female genital system mono-opisthodelphic; tail rounded to conoid. Basirotyleptus goaensis sp. nov. is characterized by having $0.73-0.87 \mathrm{~mm}$ long body; odontostyle $13.0-14.5 \mu \mathrm{m}$, odontophore $15.0-17.5 \mu \mathrm{m}$; pharyngeal bulb pyriform, $16-18 \%$ of total neck length; female genital system mono-opisthodelphic; tail rounded. Basirotyleptus neocaudatus sp. nov. is characterized by having $0.31-0.44 \mathrm{~mm}$ long body; odontostyle 7.5-9.5 $\mu \mathrm{m}$, odontophore $10-13 \mu \mathrm{m}$; pharyngeal bulb pear-shaped, $14-19 \%$ of total neck length; female genital system monoopisthodelphic; tail conoid with acute terminus. Basirotyleptus siddiqii sp. nov. is characterized by having $0.36 \mathrm{~mm}$ long body; odontostyle $7.5-8.0 \mu \mathrm{m}$, odontophore 10.0-10.5 $\mu \mathrm{m}$; pharyngeal bulb pear-shaped, $15-16 \%$ of total neck length; female genital system mono-opisthodelphic; tail conoid. Six known species viz., B. basiri, B. pini, B. nindei, B. ethiopicus, B. acus, B. minutus are also described and illustrated. Along with light microscopic study, line drawings, compendium and key to species of Basirotyleptus are also provided.
\end{abstract}

Keywords. Nematode, Leptonchidae, species description, biodiversity hotspot.

Islam M.N. \& Ahmad W. 2022. Description of five new and six known species of the genus Basirotyleptus Jairajpuri, 1964 (Nematoda: Dorylaimida: Tylencholaimoidea) from the Western Ghats, India. European Journal of Taxonomy 791: 1-57. https://doi.org/10.5852/ejt.2022.791.1645 


\section{Introduction}

The genus Basirotyleptus is a soil-inhabiting nematode taxon proposed by Jairajpuri (1964) with B. basiri as its type species from Assam, India, under the family Leptonchidae Thorne, 1964. Simultaneously, Siddiqi \& Khan (1964) proposed a genus Trichonchium with Trichonchium archium as its type species and T. eximium another species also from Assam, India. Thorne (1964) in his monographic work proposed two new genera Belonenchus with B. penetrans and Poncenema with P. striata as type species from Puerto Rico. Siddiqi \& Khan (1965) synonymized Trichonchium archium Siddiqi \& Khan, 1964 with B. basiri hence the genus Trichonchium became a junior synonym of Basirotyleptus due to priority of publications of the later. They (Siddiqi \& Khan 1965) added two more species B. pini and B. coronatus from India and also provided a key for the identification of species. Sauer (1966, from Australia), Jairajpuri (1966, from India) and Hussain \& Khan (1968, from India) added a species each to this genus. Siddiqi (1969) synonymized the genera Belonenchus Thorne, 1964 and Poncenema Thorne, 1964 with Basirotyleptus and Siddiqi (1970) added five new species and also revised the key for identification of species. Goseco et al. (1974) restudied the type material of all the known species, added two new species, $B$. lieberi and $B$. acus from Indiana, and also provide a key for the identification of species. Ahmad \& Jairajpuri (1979) further added two new species B. upicus and B. soueastus from India and Malaysia respectively, whereas, Jana \& Baqri (1981) added a new species B. minimus from India. Siddiqi (1982, 1983) proposed two new genera Coronatyleptus and Aculonchus from Colombia with several species and transferred Basirotyleptus bunocephalus Siddiqi, 1970 to the genus Glochidorella Siddiqi, 1982 based on the presence of basal knobs of the odontophore. Khan (1987) further added a species B. minutus from India. Jairajpuri \& Ahmad (1992) in their monographic work synonymized Coronatyleptus and Aculonchus with Basirotyleptus and split the genus into five subgenera viz., Coronatyleptus, Aculonchus, Trichonchium, Opisthotyleptus and Basirotyleptus, on the basis of presence or absence of labial disc, flanges at the base of odontophore and female genital system to facilitate proper grouping and easy identification. Siddiqi (1995) added several new species from Tropical rain forests of Colombia and Cameroon and Siddiqi (1997) added a species from West Indies. Dhanam \& Jairajpuri (1999) added a new species B. indicus from India. Peña-Santiago (2006) accepted Aculonchus Siddiqi, 1982 as a separate genus but did not accept the subgenera as proposed by Jaiarjpuri \& Ahmad (1992). Andrássy (2009) in his book not only accepted Aculonchus as a valid genus but also considered Trichonchium as separate genus from Basirotyleptus with T. eximium (Siddiqi \& Khan, 1964) as its type because of the presence of prodelphic female genital system. However, Trichonchium has not been considered here as a valid genus. Jairajpuri \& Ahmad (1992) doubted the validity of the genus Punctoleptus Khan, 1987 and considered it a possibly synonym of Basirotyleptus which Andrássy (2009) finally synonymized it with the later. An action which is fairly acceptable here.

In the ongoing study on the nematode fauna of Western Ghats of India, several populations representing the genus Basirotyleptus were collected from different localities. On detailed study, they were found to represent five new and six known species, which are described in this paper.

\section{Material and methods}

During the course of present study, the soil samples were collected from different localities of the Western Ghats of India. The nematodes were extracted from soil samples following Cobb's (1918) sieving and decantation and modified Baermann's funnel techniques. The extracted nematodes were fixed in hot triethanolamine-glycerol fixative, dehydrated by the slow evaporation method (Seinhorst 1959), and mounted in anhydrous glycerine. Permanent mounts were prepared using the paraffin wax ring method (de Maeseneer \& d'Herde 1963). The measurements were taken using an ocular micrometer, line drawings were made using a drawing tube, and photographs were taken with a Nikon DS digital Camera attached with Nikon Eclipse 80i microscope. Raw photographs were edited using Adobe ${ }^{\circledR}$ Photoshop ${ }^{\circledR}$. 
Type and others specimens are deposited in the nematode collection of the Department of Zoology, Aligarh Muslim University (AMU/ZD/NC), as well as in the nematode collection of the Zoological Survey of India, Kolkata, India.

\title{
List of abbreviations
}

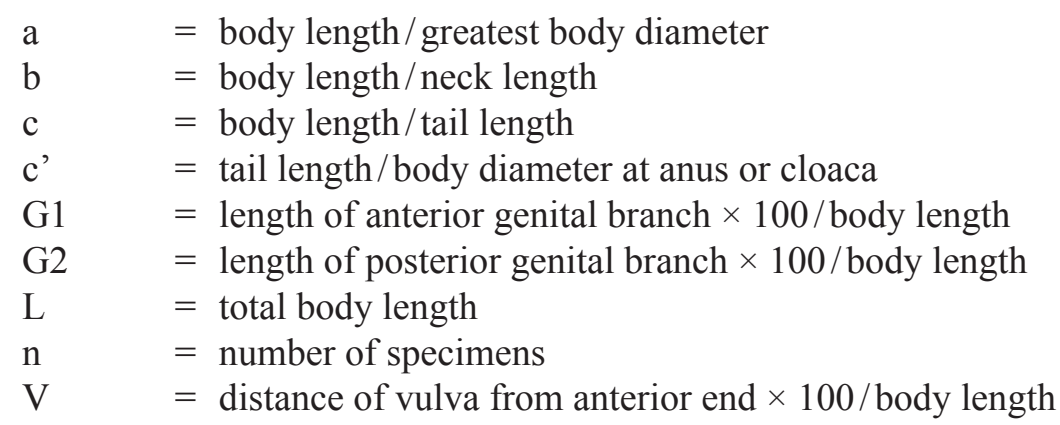

\section{Results}

\author{
Phylum Nematoda Cobb, 1932 \\ Class Enoplea Inglis, 1983 \\ Subclass Dorylaimia Inglis, 1983 \\ Order Dorylaimida Pearse, 1942 \\ Superfamily Tylencholaimoidea Filipjev, 1934 \\ Family Leptonchidae Thorne, 1964 \\ Genus Basirotyleptus Jairajpuri, 1964
}

Basirotyleptus basiri Jairajpuri, 1964

Fig. 1, Table 1

Basirotyleptus basiri Jairajpuri, 1964: 59-64.

Trichonchium archium Siddiqi \& Khan, 1964: 141-143.

Basirotyleptus basiri - Siddiqi \& Khan 1965: 23-31. — Furstenberg 1980: 154-155.

\section{Material examined}

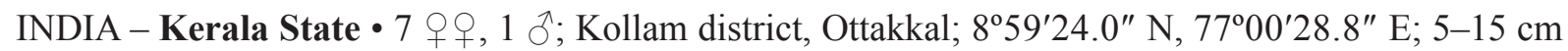
depth; 2 Nov. 2017; soil samples collected from around the roots of grasses and shrubs (unidentified); slides reference number AMU/ZD/NC/Basirotyleptus basiri/1-3 • 5 q ; ; Ernakulum district, Kalady; $11^{\circ} 03^{\prime} 40.7^{\prime \prime} \mathrm{N}, 76^{\circ} 32.7^{\prime} 23.8^{\prime \prime} \mathrm{E}$; 5-15 cm depth; 27 Oct. 2017; soil samples collected from around the roots of grasses (unidentified); slides reference number AMU/ZD/NC/Basirotyleptus basiri/4-6 8 우우 Ernakulum district, Neriamangalam; $10^{\circ} 03^{\prime} 50.4^{\prime \prime} \mathrm{N}, 76^{\circ} 41^{\prime} 38.4^{\prime \prime} \mathrm{E}$; $5-15 \mathrm{~cm}$ depth; 29 Oct. 2017; soil samples collected from around the roots of pineapple (Ananas comosus (L.) Merr.); slides reference number AMU/ZD/NC/Basirotyleptus basiri/7-9.

\section{Description}

\section{Female}

Small sized nematodes, slightly curved ventrad upon fixation; body cylindrical, tapering gradually towards both extremities but more so towards anterior end. Cuticle with two distinct layers, 1.0$1.5 \mu \mathrm{m}$ thick at anterior region, $1.5-2.0 \mu \mathrm{m}$ at midbody and $2.5-3.0 \mu \mathrm{m}$ on tail. Outer cuticle thin, with transverse striations; inner layer thick, its outline loose, irregular, distinctly striated, with radial refractive elements. Lateral chords occupying about $28-35 \%$ of midbody diameter. Lateral body pores 

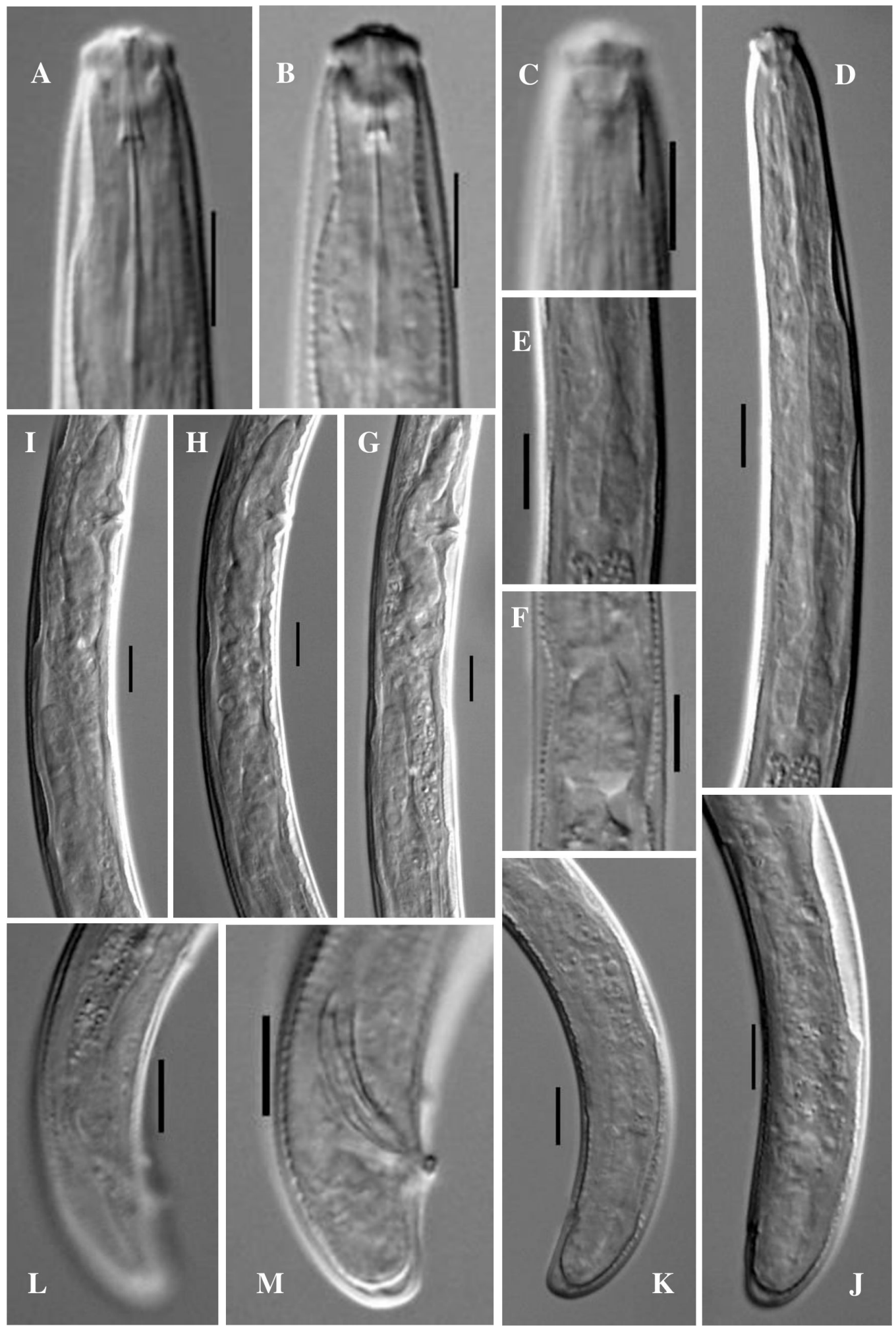

Fig. 1. Basirotyleptus basiri Jairajpuri, 1964(AMU/ZD/NC/Basirotyleptus basiri/1-3)(LM photographs). A-B. Female, anterior region. C. Female, anterior region showing amphid. D. Female, pharyngeal region. E-F. Female, pharyngeal bulb. G-I. Female, genital system. J-K. Female, posterior region. L-M. Male, posterior end. Scale bars $=10 \mu \mathrm{m}$. 
Table 1. Measurements of Basirotyleptus basiri Jairajpuri, 1964. All measurements are in $\mu \mathrm{m}$ and in the form: mean \pm s.d. (range).

\begin{tabular}{|c|c|c|c|c|}
\hline \multirow{2}{*}{$\begin{array}{l}\text { Localities } \\
\text { Characters }\end{array}$} & \multicolumn{2}{|c|}{ Kollam population } & \multirow{2}{*}{$\begin{array}{c}\text { Kalady population } \\
\text { Females }\end{array}$} & \multirow{2}{*}{$\begin{array}{c}\text { Neriamangalum population } \\
\text { Females }\end{array}$} \\
\hline & Females & Male & & \\
\hline $\mathrm{n}$ & 7 & 1 & 5 & 8 \\
\hline $\mathrm{L}$ & $501.0 \pm 22.2(462-537)$ & 498 & $493.7 \pm 32.5(458-541)$ & $508.8 \pm 27.4(474-549)$ \\
\hline Body diameter at neck base & $17.6 \pm 0.90(15.5-18.5)$ & 17.0 & $18.0 \pm 0.99(16.5-19.5)$ & $17.8 \pm 0.94(16.5-19.5)$ \\
\hline Body diameter at mid body & $19.6 \pm 0.52(18.5-20.5)$ & 17.5 & $19.2 \pm 1.1(17.5-20.5)$ & $19.1 \pm 1.3(17.5-21.5)$ \\
\hline Body diameter at anus & $14.1 \pm 0.48(13.5-14.5)$ & 14.5 & $14.3 \pm 1.3(12.5-16.5)$ & $13.7 \pm 0.98(11.5-14.5)$ \\
\hline a & $25.5 \pm 1.0(23.6-26.7)$ & 28.2 & $25.8 \pm 2.3(22.3-29.3)$ & $26.6 \pm 1.3(24.4-28.1)$ \\
\hline $\mathrm{b}$ & $4.6 \pm 0.22(4.2-4.9)$ & 4.9 & $4.5 \pm 0.31(4.0-4.9)$ & $4.6 \pm 0.33(4.3-4.8)$ \\
\hline c & $40.2 \pm 1.9(36.4-42.4)$ & 33.9 & $42.7 \pm 0.81(41.7-44.0)$ & $41.4 \pm 3.6(35.8-47.5)$ \\
\hline$c^{\prime}$ & $0.88 \pm 0.04(0.8-1.0)$ & 1.0 & $0.88 \pm 0.05(0.84-1.0)$ & $0.90 \pm 0.08(0.78-1.0)$ \\
\hline $\mathrm{V}$ & $37.3 \pm 1.6(35.5-40.1)$ & - & $39.1 \pm 2.3(37.1-43.2)$ & $39.8 \pm 1.7(37.7-42.9)$ \\
\hline G1 & $4.4 \pm 0.45(3.8-5.3)$ & - & $4.6 \pm 0.79(3.6-5.7)$ & $5.0 \pm 0.86(3.5-6.1)$ \\
\hline $\mathrm{G} 2$ & $19.6 \pm 3.0(16.9-27.1)$ & - & $21.7 \pm 5.0(17.7-31.1)$ & $18.9 \pm 2.6(15.4-25.0)$ \\
\hline Lip region diameter & $8.1 \pm 0.24(8.0-8.5)$ & 8.5 & $8.2 \pm 0.24(8.0-8.5)$ & $8.1 \pm 0.25(8.0-8.5)$ \\
\hline Lip region height & $3.6 \pm 0.17(3.5-4.0)$ & 3.5 & $3.7 \pm 0.2(3.5-4.0)$ & $3.6 \pm 0.25(3.5-4.0)$ \\
\hline Amphidial aperture & $4.3 \pm 0.31(4.0-5.0)$ & 5.0 & $4.4 \pm 0.43(4.0-5.0)$ & $4.7 \pm 0.21(4.5-5.0)$ \\
\hline Odontostyle length & $11.0 \pm 0.44(10.5-11.5)$ & 10.5 & $11.5 \pm 0.19(11.0-12.0)$ & $11.5 \pm 0.40(10.5-11.5)$ \\
\hline Odontophore length & $11.6 \pm 0.22(11.5-12.0)$ & 12.5 & $12.3 \pm 0.58(11.5-13.0)$ & $12.2 \pm 0.42(11.5-13.0)$ \\
\hline Total stylet length & $22.6 \pm 0.56(22.0-23.0)$ & 23 & $23.7 \pm 0.73(22.5-24.5)$ & $23.3 \pm 0.63(22.5-24.5)$ \\
\hline Guiding ring from anterior end & $9.4 \pm 0.56(8.5-9.5)$ & 10 & $9.4 \pm 0.48(9.0-10)$ & $9.5 \pm 0.42(9.0-10)$ \\
\hline Nerve ring from anterior end & $61.6 \pm 2.4(57-66)$ & 58 & $59.1 \pm 4.1(54-64)$ & $58.8 \pm 2.6(53-62)$ \\
\hline Neck length & $108.0 \pm 2.8(103-112)$ & 99 & $108.7 \pm 8.3(100-123)$ & $106.4 \pm 3.4(100-110)$ \\
\hline Expanded part of pharynx & $17.2 \pm 0.48(16.5-17.5)$ & 17.5 & $18.4 \pm 1.4(16.5-20.5)$ & $17.1 \pm 0.69(16.5-18.5)$ \\
\hline Cardia length & $4.7 \pm 0.36(4.0-5.0)$ & 4.0 & $4.5 \pm 0.48(4.0-5.0)$ & $4.3 \pm 0.48(4.0-5.0)$ \\
\hline Anterior genital branch & $22.6 \pm 2.3(19-26)$ & - & $23.3 \pm 3.4(18.5-26.5)$ & $26.0 \pm 3.5(19.5-30.0)$ \\
\hline Posterior genital branch & $99.9 \pm 12.3(85-125)$ & - & $109.1 \pm 23.8(86-152)$ & $97.8 \pm 10.4(84-118)$ \\
\hline Vaginal length & $10.3 \pm 0.68(9.5-10.5)$ & - & $11.1 \pm 0.48(10.5-11.5)$ & $11.2 \pm 0.45(10.5-11.5)$ \\
\hline Vulva from anterior end & $186.7 \pm 8.9(174-200)$ & - & $192.8 \pm 8.8(182-205)$ & $202.3 \pm 8.6(188-214)$ \\
\hline Prerectum length & $35.7 \pm 5.0(30-44)$ & 31 & $41.7 \pm 2.9(36-44)$ & $32.3 \pm 2.1(29-35)$ \\
\hline Rectum length & $16.6 \pm 2.5(13.5-20.0)$ & 20 & $16.8 \pm 2.9(11.5-19.5)$ & $16.0 \pm 2.4(13-19.5)$ \\
\hline Tail length & $12.4 \pm 0.68(11.5-13.5)$ & 14.5 & $12.7 \pm 2.0(11-16)$ & $12.3 \pm 1.2(11-15)$ \\
\hline Spicules length & - & 20 & - & - \\
\hline Lateral guiding pieces & - & 5.5 & - & - \\
\hline Ventromedian supplements & - & 1 & - & - \\
\hline
\end{tabular}


distinct; $1-3$ in neck region; $2-3$ at neck to vulval region and 4-7 at post-vulval region. Dorsal and ventral body pores indistinct. Lip region cap-like, offset by slight constriction, 2.0-2.4 times as wide as high or about two-fifths to one-half of the body diameter at neck base. Lips rounded, amalgamated, inner part elevated. Labial and cephalic papillae distinct and slightly raised above the labial contour. Amphids stirrup-shaped, their aperture about one-half to three-fifths as wide as lip region diameter. Stoma a long, slender truncate cone, slightly sclerotized in the perioral region. Odontostyle slender, solid, needlelike, 1.2-1.5 times the lip region diameter long. Odontophore simple, sclerotized, about 1.0-1.1 times the odontostyle length. Guiding ring simple, refractive, at 1.0-1.3 times the lip region diameter from anterior end. Pharynx consisting of a slender anterior part, expanding gradually into a short, pear-shaped basal bulb, with a perceptible thickening at the posterior part of its inner lining, occupying about 15$17 \%$ of total neck length. Nerve ring at $51-60 \%$ of neck length from anterior end. Cardia short, rounded to conoid, about one-fifth of the corresponding body diameter long.

Genital system monodelphic-opisthodelphic. Ovary reflexed, measuring 41-98 $\mu \mathrm{m}$; oocytes arranged in single row except near tip. Oviduct joining the ovary subterminally, measuring $45-81 \mu \mathrm{m}$, consisting of a slender distal portion and a well-developed pars dilatata. Oviduct-uterus junction marked by welldeveloped sphincter. Uterus short and tubular, measuring 21-36 $\mu \mathrm{m}$. Anterior genital branch reduced to a simple sac, 1.0-1.4 times the midbody diameter long. Sperm cell absent. Vagina cylindrical, extending inwards, $9.5-11.5 \mu \mathrm{m}$ or about one-half to three-fifths $(50-61 \%)$ of midbody diameter; pars proximalis vaginae 5.5-7.5 $\times 4.5-6.0 \mu \mathrm{m}$, encircled by circular muscles; pars distalis vaginae long, 4.0-5.0 $\mu \mathrm{m}$ with slightly curved walls; pars refringens absent. Vulva apparently a transverse slit. Prerectum 2.0-3.2 and rectum 0.8-1.2 times anal body diameter long. Tail short, rounded to conoid, $0.8-1.0$ times anal body diameter long, with a pair of caudal pores on each side.

\section{Male}

General morphology similar to that of female except for posterior region being more ventrally curved. Genital system diorchic, testes opposed, sperm cell spindle-shaped. In addition to adcloacal pair situated at $6 \mu \mathrm{m}$ from cloacal aperture, there is single ventromedian supplement located at $25 \mu \mathrm{m}$ from adcloacal pair, beyond the range of spicules. Spicules typically dorylaimoid, curved ventrad, slightly robust, 5.0 times as long as wide and 1.3 times as long as cloacal body diameter, dorsal contour regularly convex, ventral contour bearing a moderately developed hump and hollow, curvature $132^{\circ}$, head occupying $20 \%$ of total spicules length, median pieces 10.6 times as long as wide or occupying about $37 \%$ of the spicules maximum width, reaching the spicules tip, posterior end $2.5 \mu \mathrm{m}$ wide. Lateral guiding pieces distinct, rod-like, about 5.0 times as long as wide or about one-fourth of the spicules length. Prerectum 3.0 and rectum 1.4 times cloacal body diameter long. Tail short rounded to conoid, about as long as the cloacal body diameter, with a pair of caudal pores on each side.

\section{Remarks}

Jairajpuri (1964) proposed the genus Basirotyleptus with B. basiri as its type species from Jorhat, Assam, India. Siddiqi \& Khan $(1964,1965)$ recorded this species from Assam and Madhya Pradesh respectively. Furstenberg (1980) described this species from Malaysia, whereas, Shamim et al. (2014) from Pakistan. The morphometrics of present populations conform well with the type population except in having slightly lower c (35-47 vs 45-58) ratio and presence of male (vs absent). The present populations also conform well with Siddiqi \& Khan (1964) population except in having slightly shorter body $(0.45-0.54$ vs $0.59-0.67 \mathrm{~mm})$; lower b (4.0-4.9 vs 5.4-6.4) and c (36-47 vs 47-56) ratios and presence of male (vs absent). The present specimens also conform well with Madhya Pradesh population described by Siddiqi \& Khan (1965) except in having short and robust body $(0.45-0.54$ vs $0.68-0.71 \mathrm{~mm}$, a $=22-29$ vs 29-31); slightly shorter odontostyle (10.5-12 vs $13-14 \mu \mathrm{m})$; lower b (4.0-4.9 vs 6.3-6.5) and c (3647 vs $58-61)$ ratios and smaller spicules ( 20 vs $25-26 \mu \mathrm{m})$. The morphometrics of present populations agree well with the Malaysia population except in having slightly longer odontostyle (10.5-12.0 vs 
9.3-10.5 $\mu \mathrm{m})$; longer rectum (11.5-20.0 vs 10-11 $\mu \mathrm{m})$ and presence of male (vs absent). The present populations conform well with the Pakistan population except in having shorter body $(0.45-0.54$ vs $0.63-0.78 \mathrm{~mm})$; lower b (4.0-4.9 vs 5.0-6.8), lower c (35-47 vs 56-69) ratios and slighter higher c' $(0.7-1.0$ vs $0.5-0.7)$ ratio. These differences are considered here as intraspecific variability. This species is recorded here for the first time from the Western Ghats.

Basirotyleptus pini Siddiqi \& Khan, 1965

Fig. 2, Table 2

Basirotyleptus pini Siddiqi \& Khan, 1965: 641-645.

Basirotyleptus pini - Baqri 1991: 75-77. — Li et al. 2008: 2008-2009.

\section{Material examined}

INDIA - Kerala State • 9 o o; Kollam district, Pathanampuram; 905'34.8” N, 7651'39.6" E; 5-15 cm depth; 3 Nov. 2017; soil samples collected from around the roots of grasses (unidentified); slides reference number AMU/ZD/NC/Basirotyleptus pini/1-3 - 9 + $q$; Pathanamthitta district, Thannithode; $9^{\circ} 15^{\prime} 21.6^{\prime \prime} \mathrm{N}, 76^{\circ} 55^{\prime} 19.2^{\prime \prime}$ E; 5-15 cm depth; 1 Nov. 2017; soil samples collected from around the roots of shrubs (unidentified); slides reference number AMU/ZD/NC/Basirotyleptus pini/4-6.

\section{Description}

\section{Female}

Small sized nematodes, slightly curved ventrad or open C-shaped upon fixation; tapering gradually towards both extremities but more so towards anterior end. Cuticle with two distinct layers, $1.0-1.5 \mu \mathrm{m}$ thick at anterior region, $2.0-2.5 \mu \mathrm{m}$ at midbody and 2.5-3.5 $\mu \mathrm{m}$ on tail. Outer cuticle thin, smooth or with very fine transverse striations; inner layer thick, its outline irregular, loose, finely striated, with radial refractive elements. Lateral chords occupying about $30-35 \%$ of midbody diameter. Lateral body pores distinct; $1-2$ in neck region; 2-3 at neck to vulval region and 5-9 at post-vulval region. Dorsal and ventral body pores indistinct. Lip region cap-like, offset by deep constriction, 2.1-2.5 times as wide as high or about two-fifths to one-half of the body diameter at neck base. Lips rounded, amalgamated, angular, projected, inner part elevated. Labial and cephalic papillae distinct and slightly raised above the labial contour. Amphids stirrup-shaped, their aperture about one-half to three-fifths as wide as lip region diameter. Stoma a long, slender truncate cone, slightly sclerotized in the perioral region. Odontostyle slender, solid, needle-like, 1.3-1.5 times the lip region diameter long. Odontophore simple, sclerotized, slightly swollen at base surrounded by pharyngeal tissue, 1.0-1.1 times the odontostyle length. Guiding ring simple, refractive, at 1.2-1.3 times the lip region diameter from anterior end. Pharynx consisting of a slender anterior part, expanding gradually into a short, pear-shaped basal bulb, with a perceptible thickening at the posterior part of its inner lining, occupying about $14-17 \%$ of total neck length. Nerve ring at $50-59 \%$ of neck length from anterior end. Cardia short, rounded to conoid, about one-fifth to one-third of the corresponding body diameter long.

Genital system monodelphic-opisthodelphic. Ovary reflexed, measuring 56-98 $\mu \mathrm{m}$; oocytes arranged in single row except near tip. Oviduct joining the ovary subterminally, measuring $45-95 \mu \mathrm{m}$, consisting of a slender distal portion and a well-developed pars dilatata. Oviduct-uterus junction marked by weak sphincter. Uterus short and tubular, measuring 19-31 $\mu \mathrm{m}$. Anterior genital branch reduced to small sac, $0.40-0.81$ times midbody diameter long. Sperm cell absent. Vagina cylindrical, extending inwards, $10.5-12.5 \mu \mathrm{m}$ or about one-half to three-fifths $(50-62 \%)$ of midbody diameter; pars proximalis vaginae $6.0-7.5 \times 4.0-6.5 \mu \mathrm{m}$, encircled by circular muscles; pars distalis vaginae $4.0-5.0 \mu \mathrm{m}$ with slightly curved walls; pars refringens absent. Vulva apparently a transverse slit. Prerectum 2.0-3.5 and rectum 


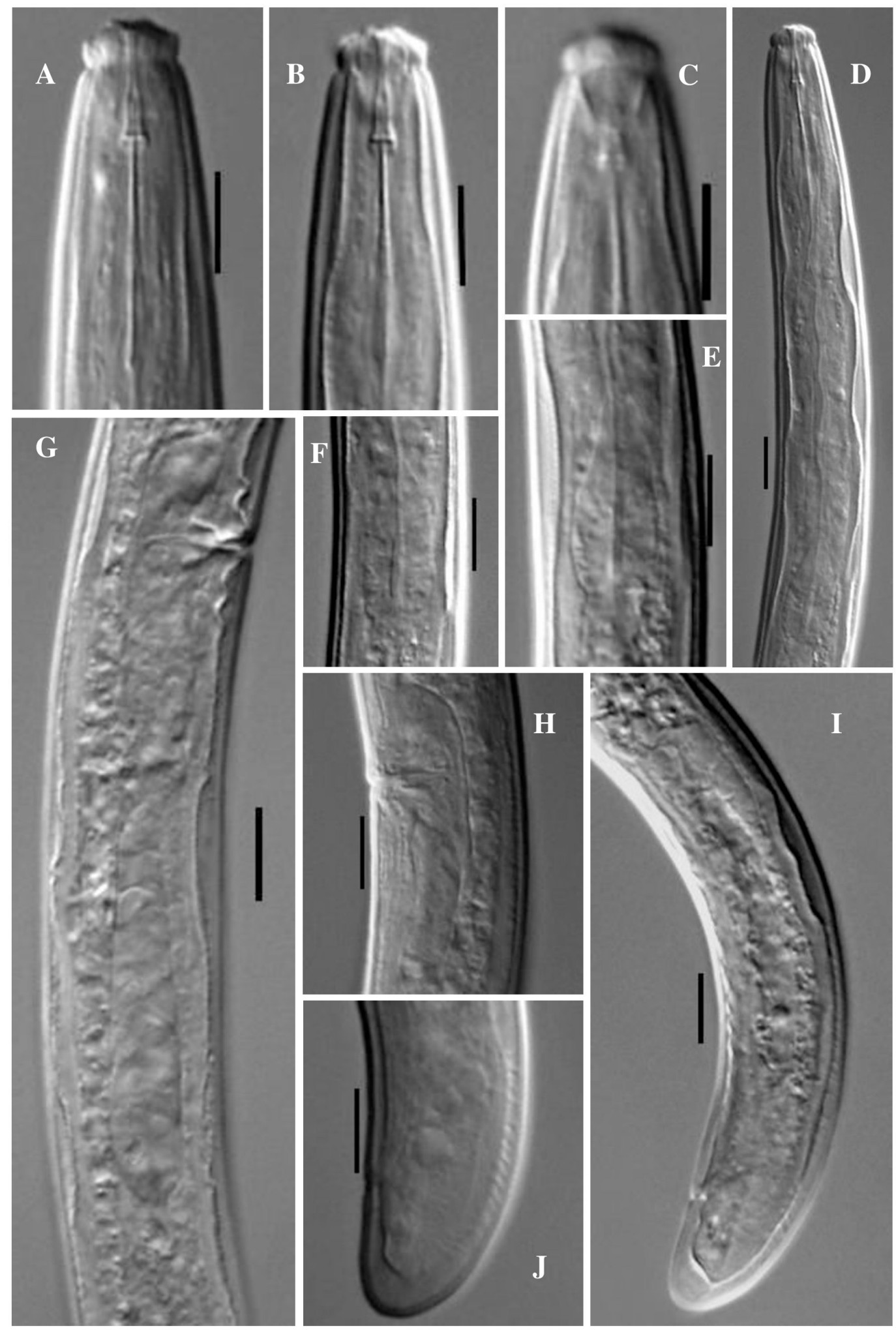

Fig. 2. Basirotyleptus pini Siddiqi \& Khan, 1964, q (AMU/ZD/NC/Basirotyleptus pini/1-3) (LM photographs). A-B. Anterior region. C. Anterior region showing amphid. D. Pharyngeal region. E-F. Pharyngeal bulb. G. Genital system. H. Vulval region. I. Posterior region. J. Posterior end. Scale bars $=10 \mu \mathrm{m}$. 
Table 2. Measurements of Basirotyleptus pini Siddiqi \& Khan, 1964. All measurements are in $\mu \mathrm{m}$ and in the form: mean \pm s.d. (range).

\begin{tabular}{|c|c|c|}
\hline Localities & Kollam population & Pathanamthitta population \\
\hline Characters & Females & Females \\
\hline $\mathrm{n}$ & 9 & 9 \\
\hline $\mathrm{L}$ & $522.9 \pm 23.0(465-575)$ & $522.5 \pm 28.9(453-556)$ \\
\hline Body diameter at neck base & $19.6 \pm 0.65(18.5-20.5)$ & $19.3 \pm 0.61(18.5-20.5)$ \\
\hline Body diameter at mid body & $20.9 \pm 0.65(19.5-21.5)$ & $21.2 \pm 0.80(19.5-22.5)$ \\
\hline Body diameter at anus & $15.5 \pm 0.55(14.5-16.5)$ & $15.5 \pm 0.85(13.5-16.5)$ \\
\hline $\mathrm{a}$ & $25.0 \pm 1.3(22.6-26.7)$ & $24.6 \pm 0.85(23.1-25.8)$ \\
\hline $\mathrm{b}$ & $4.5 \pm 0.24(4.1-4.9)$ & $4.4 \pm 0.20(4.0-4.8)$ \\
\hline $\mathrm{c}$ & $37.2 \pm 1.7(33.9-39.1)$ & $37.9 \pm 3.1(33.3-43.0)$ \\
\hline$c^{\prime}$ & $0.90 \pm 0.05(0.81-1.0)$ & $0.88 \pm 0.06(0.76-1.0)$ \\
\hline V & $38.7 \pm 1.0(37.5-40.6)$ & $37.2 \pm 1.5(35.5-40.2)$ \\
\hline G1 & $2.9 \pm 0.81(2.2-5.0)$ & $2.3 \pm 0.43(1.5-3.0)$ \\
\hline G2 & $19.9 \pm 2.4(17.0-24.8)$ & $21.6 \pm 3.4(16.4-27.4)$ \\
\hline Lip region diameter & $8.6 \pm 0.24(8.5-9.0)$ & $8.7 \pm 0.15(8.5-9.0)$ \\
\hline Lip region height & $3.8 \pm 0.20(3.5-4.0)$ & $3.8 \pm 0.20(3.5-4.0)$ \\
\hline Amphidial aperture & $4.8 \pm 0.15(4.5-5.0)$ & $4.7 \pm 0.20(4.5-5.0)$ \\
\hline Odontostyle length & $12.3 \pm 0.27(11.5-12.5)$ & $11.5 \pm 0.30(11-12)$ \\
\hline Odontophore length & $13.2 \pm 0.46(12.5-14.0)$ & $13.8 \pm 0.46(12.5-14.0)$ \\
\hline Total stylet length & $25.5 \pm 0.63(25-26)$ & $25.4 \pm 0.70(24.5-26.0)$ \\
\hline Guiding ring from anterior end & $10.8 \pm 0.20(10.5-11.0)$ & $10.9 \pm 0.23(10-11)$ \\
\hline Nerve ring from anterior end & $63.8 \pm 2.5(58-66)$ & $63.2 \pm 2.8(58-66)$ \\
\hline Neck length & $115.7 \pm 4.2(105-121)$ & $117.0 \pm 3.9(110-124)$ \\
\hline Expanded part of pharynx & $19.1 \pm 0.93(17.5-20.5)$ & $18.6 \pm 1.0(17-20)$ \\
\hline Cardia length & $5.3 \pm 0.58(4.5-5.5)$ & $4.7 \pm 0.56(4.0-6.0)$ \\
\hline Anterior genital branch & $14.5 \pm 2.0(11-18)$ & $12.5 \pm 2.5(8.0-17)$ \\
\hline Posterior genital branch & $106.1 \pm 10.8(89-119)$ & $114.6 \pm 14.4(91-142)$ \\
\hline Vaginal length & $11.3 \pm 0.67(10.5-12.5)$ & $11.5 \pm 0.65(10.5-12.5)$ \\
\hline Vulva from anterior end & $202.6 \pm 9.5(185-217)$ & $194.8 \pm 12.59(172-222)$ \\
\hline Prerectum length & $40.6 \pm 5.9(29-47)$ & $42.4 \pm 5.2(37-49)$ \\
\hline Rectum length & $18.9 \pm 0.80(17.5-19.5)$ & $19.7 \pm 0.97(18.5-21.5)$ \\
\hline Tail length & $14.0 \pm 0.80(12.5-16.0)$ & $13.8 \pm 1.1(12-15)$ \\
\hline
\end{tabular}


1.1-1.3 times anal body diameter long. Tail short, rounded to conoid, $0.7-1.0$ times anal body diameter long, with a pair of caudal pores on each side.

Male

Not found.

\section{Remarks}

Siddiqi \& Khan (1965) described this species from Kashmir, India. Baqri (1991) reported it from South Sikkim, India, whereas, Li et al. (2008) recorded it from the China. The morphometrics of present populations conform well with the type population except in having slightly lower c ratio (33-43 vs 43-55). The present populations conform well with the Sikkim population except for longer total stylet (24.5-26.0 vs 18-23) and odontostyle (11.0-12.5 vs 8.0-9.0 $\mu \mathrm{m})$; lower c (33-43 vs 50-60) and higher c' $(0.76-1.0$ vs $0.6-0.7)$ ratios, and longer tail $(12-16$ vs $8.0-9.0 \mu \mathrm{m})$. The present specimens also conform well with the Chinese specimens except in having anterior vulva position ( $\mathrm{V}=35.5-40.6$ vs $42.0-43.5)$; slightly longer tail (12-16 vs 10-13 $\mu \mathrm{m})$ and lower c ratio (33-43 vs 55-61). Goseco et al. (1974) in their revision of the genus Basirotyleptus restudied the type material of B. pini and they observed amphids are duplex, stirrup-shaped, but Siddiqi \& Khan (1965) in their description mentioned that amphids are simple, stirrup-shaped. Whereas Baqri (1991) mentioned amphids as simple cup-shaped. The shape of amphids is apparently difficult to observe and in present specimens the amphids appeared as simple, stirrup-shaped. This species is recorded here for the first time from the Western Ghats.

In the presence of simple odontophore and anterior uterine sac, this species also comes close to Basirotyleptus basiri Jairajpuri, 1964 but differs in having outer and inner cuticle finely striated (vs distinctly striated), lip region offset by deep constriction (vs slight constriction) and shorter anterior uterine branch (two-fifths to two-thirds vs always more than midbody diameter long).

\section{Basirotyleptus nindei Siddiqi, 1970}

Fig. 3, Table 3

Basirotyleptus nindei Siddiqi, 1970: 203-205.

\section{Material examined}

INDIA - Kerala State • 11 q ; Pathanamthitta district, Thannithodu forest; $9^{\circ} 15^{\prime 2} 21.6^{\prime \prime}$ N, $76^{\circ} 55^{\prime} 19.2^{\prime \prime}$ E; 5-15 cm depth; 1 Nov. 2017; soil samples collected from around the roots of shrubs (unidentified); slides reference number AMU/ZD/NC/Basirotyleptus nindei/1-4 • 7 q $\%$; Ernakulum district, Manikandanchal; $10^{\circ} 09^{\prime} 28.8^{\prime \prime} \mathrm{N}, 76^{\circ} 47^{\prime} 56.4^{\prime \prime} \mathrm{E}$; 5-15 cm depth; 28 Oct. 2017; soil samples collected from around the roots of shrubs (unidentified); slides reference number AMU/ZD/NC/Basirotyleptus nindei/5-7.

\section{Description}

\section{Female}

Small sized nematodes, slightly curved ventrad or open C-shaped upon fixation; body cylindrical tapering gradually towards both extremities but more so towards the anterior end. Cuticle with two distinct layers, $1.0-1.5 \mu \mathrm{m}$ thick at anterior region, $1.5-2.0 \mu \mathrm{m}$ at midbody and $2.5-3.0 \mu \mathrm{m}$ on tail. Outer cuticle thin, with fine transverse striations; inner layer thick, finely striated, loose, its outline irregular, with distinct radial refractive elements. Lateral chords occupying about $29-35 \%$ of midbody diameter. Lateral body pores distinct; $1-2$ in neck region; $1-2$ from pharyngeal base to vulva; $2-4$ in post-vulval region. Dorsal and ventral body pores indistinct. Lip region cap-like, offset by constriction, 1.8-2.1 times as wide as high or about one-third to two-fifths of the body diameter at neck base. Lips angular, separate, inner part elevated. Labial and cephalic papillae distinct but not interfering with labial contour. Amphids stirrupshaped, their aperture about two-fifths to one-half as wide as lip region diameter. Stoma a long, slender 

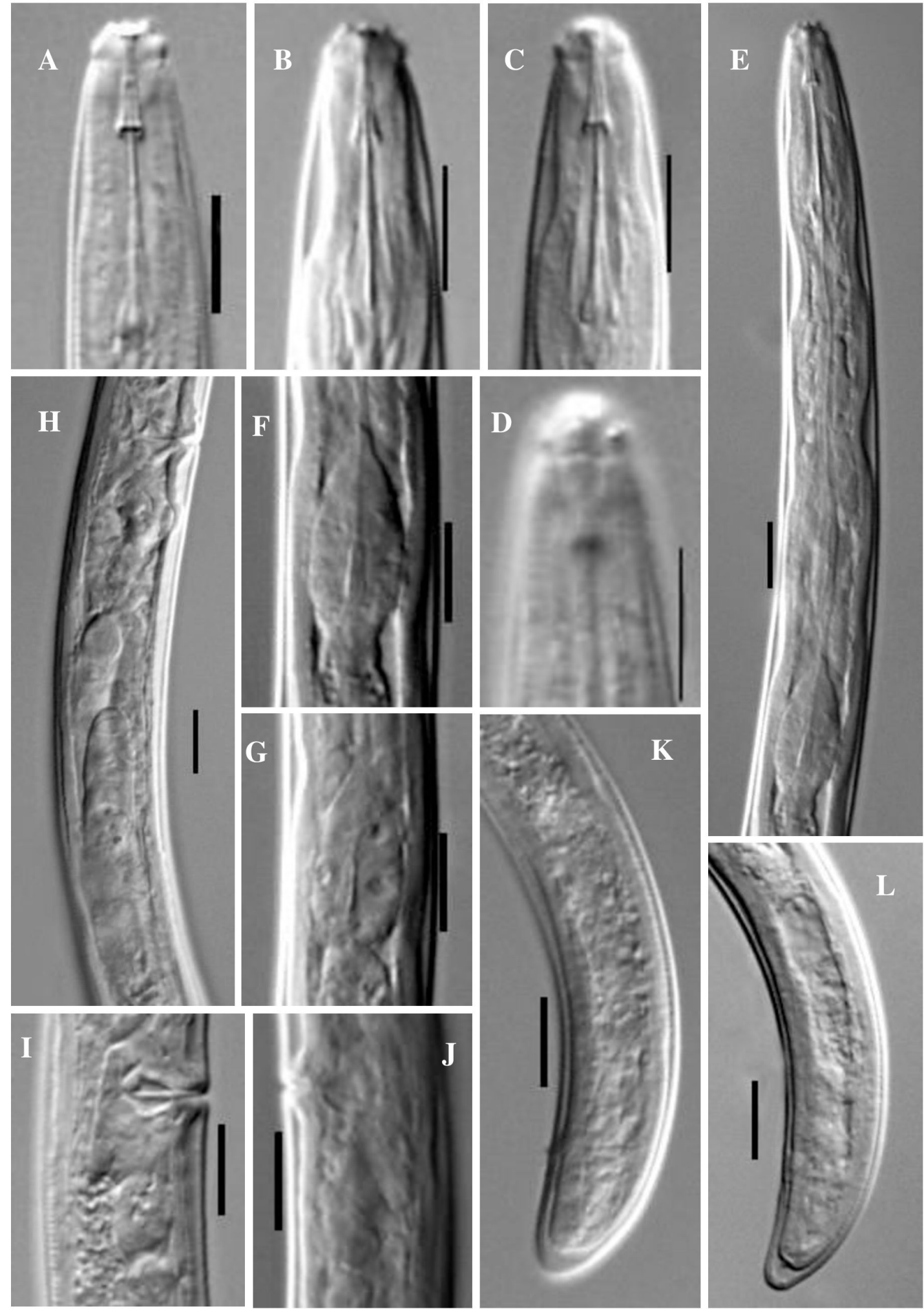

Fig. 3. Basirotyleptus nindei Siddiqi, 1970, \& (AMU/ZD/NC/Basirotyleptus nindei/1-4) (LM photographs). A-C. Anterior region. D. Anterior region showing amphid. E. Pharyngeal region. F-G. Pharyngeal bulb. H. Genital system. I-J. Vulval region. K-L. Posterior region. Scale bars = $10 \mu \mathrm{m}$. 
Table 3. Measurements of Basirotyleptus nindei Siddiqi, 1970. All measurements are in $\mu \mathrm{m}$ and in the form: mean \pm s.d. (range).

\begin{tabular}{|c|c|c|}
\hline Localities & Pathanamthitta population & Ernakulum population \\
\hline Characters & Females & Females \\
\hline $\mathrm{n}$ & 11 & 7 \\
\hline $\mathrm{L}$ & $415.4 \pm 13.9(393-438)$ & $432.8 \pm 19.8(391-448)$ \\
\hline Body diameter at neck base & $16.1 \pm 0.48(15.5-16.5)$ & $16.6 \pm 0.90(14.5-17.5)$ \\
\hline Body diameter at mid body & $19.1 \pm 1.6(16.5-21.5)$ & $17.9 \pm 1.1(16.5-19.5)$ \\
\hline Body diameter at anus & $11.4 \pm 0.43(10.5-11.5)$ & $11.4 \pm 0.68(10.5-12.5)$ \\
\hline $\mathrm{a}$ & $21.8 \pm 1.6(19.1-24.3)$ & $24.0 \pm 0.65(22.9-25.0)$ \\
\hline $\mathrm{b}$ & $3.9 \pm 0.16(3.6-4.1)$ & $3.9 \pm 03.0(3.5-4.5)$ \\
\hline $\mathrm{c}$ & $34.1 \pm 1.9(30.3-36.8)$ & $35.3 \pm 2.6(30.5-38.1)$ \\
\hline$c^{\prime}$ & $1.02 \pm 0.07(1.0-1.2)$ & $1.03 \pm 0.06(1.0-1.1)$ \\
\hline V & $42.4 \pm 1.6(39.6-45.1)$ & $42.5 \pm 1.2(40.9-44.3)$ \\
\hline G1 & $1.3 \pm 0.17(1.1-1.6)$ & $1.2 \pm 0.12(1.0-1.4)$ \\
\hline G2 & $22.1 \pm 2.2(17.6-25.7)$ & $23.0 \pm 2.6(19.4-26.9)$ \\
\hline Lip region diameter & $6.2 \pm 0.30(6.0-7.0)$ & $6.7 \pm 0.17(6.5-7.0)$ \\
\hline Lip region height & $3.2 \pm 0.22(3.0-3.5)$ & $3.2 \pm 0.22(3.0-3.5)$ \\
\hline Amphidial aperture & $3.1 \pm 0.24(3.0-3.5)$ & $3.2 \pm 0.22(3.0-3.5)$ \\
\hline Odontostyle length & $9.5 \pm 0.38(9.0-10)$ & $9.8 \pm 0.31(9.5-10.5)$ \\
\hline Odontophore length & $10.7 \pm 0.29(10.5-11.5)$ & $11.03 \pm 0.35(11-12)$ \\
\hline Total stylet length & $20.3 \pm 0.56(19-21)$ & $20.9 \pm 0.50(20.0-21.5)$ \\
\hline Guiding ring from anterior end & $8.5 \pm 0.24(8.5-9.0)$ & $8.6 \pm 0.22(8.5-9.0)$ \\
\hline Nerve ring from anterior end & $61.7 \pm 2.3(58-66)$ & $61.0 \pm 2.4(55-63)$ \\
\hline Neck length & $106.6 \pm 4.2(97-113)$ & $109.3 \pm 4.4(98-112)$ \\
\hline Expanded part of pharynx & $16.9 \pm 0.78(15.5-18.0)$ & $18.0 \pm 1.1(15.5-19.5)$ \\
\hline Cardia length & $4.2 \pm 0.39(4.0-5.0)$ & $4.4 \pm 0.37(4.0-5.0)$ \\
\hline Anterior genital branch & $5.6 \pm 0.69(5.0-6.0)$ & $5.3 \pm 0.40(4.5-6.0)$ \\
\hline Posterior genital branch & $94.0 \pm 10.2(74-112)$ & $102.2 \pm 14.3(78-120)$ \\
\hline Vaginal length & $9.3 \pm 0.44(8.5-9.5)$ & $9.5 \pm 0.35(8.5-9.5)$ \\
\hline Vulva from anterior end & $176.3 \pm 10.8(160-197)$ & $184.2 \pm 7.2(173-195)$ \\
\hline Prerectum length & $29.5 \pm 2.7(25-36)$ & $30.5 \pm 4.7(24.0-37.0)$ \\
\hline Rectum length & $14.3 \pm 0.86(12.5-15.5)$ & $14.1 \pm 1.2(11.5-15.5)$ \\
\hline Tail length & $12.2 \pm 0.76(11.0-13.5)$ & $12.3 \pm 1.0(11.0-13.5)$ \\
\hline
\end{tabular}


truncate cone, slightly sclerotized in the perioral region. Odontostyle slender, solid, needle-like, 1.4-1.5 times the lip region diameter long. Odontophore sclerotized, with prominent basal flanges, about 1.0-1.2 times the odontostyle length. Guiding ring simple, refractive, at 1.2-1.7 times the lip region diameter from anterior end. Pharynx consisting of a slender anterior part, expanding abruptly into a short pearshaped basal bulb, with a perceptible thickening at the posterior part of its inner lining, occupying about $14-18 \%$ of total neck length. Nerve ring located at $53-60 \%$ of neck length from anterior end. Cardia rounded to conoid, about one-fourth to one-third of the corresponding body diameter long.

Genital system monodelphic-opisthodelphic. Ovary reflexed, measuring 37-84 $\mu \mathrm{m}$; oocytes arranged in single row except near tip. Oviduct joining the ovary subterminally, measuring 39-81 $\mu \mathrm{m}$, consisting of a slender distal portion and a well-developed pars dilatata. Oviduct-uterus junction marked by weak sphincter. Uterus short and muscular, measuring 16-25 $\mu \mathrm{m}$. Anterior genital branch absent or rarely present $(n=7)$, reduced to a very small sac, about one-fifth to one-fourth midbody diameter long. Sperm cell absent. Vagina cylindrical, extending inwards, $8.5-9.5 \mu \mathrm{m}$ or about two-fifths to one-half $(43-52 \%)$ of midbody diameter; pars proximalis vaginae 5.0-7.0 $\times 4.0-5.0 \mu \mathrm{m}$, encircled by circular muscles; pars distalis vaginae 3.0-4.0 $\mu \mathrm{m}$ with slightly curved walls; pars refringens absent. Vulva apparently a transverse slit. Prerectum 2.0-3.1 and rectum 1.0-1.4 times anal body diameter long. Tail short, rounded to conoid, with a pair of caudal pores on each side.

\section{Male}

Not found.

\section{Remarks}

Siddiqi (1970) described this species from the Malawi. During the present study eighteen females were collected from two different localities of the Western Ghats, India. The morphometrics of present populations conform well with the type population except in having differently shaped amphids (stirrupshaped vs cup-shaped), slightly shorter odontostyle $(9.0-10.5 \mathrm{vs} 11.0 \mu \mathrm{m})$, slightly longer odontophore (10.5-12 vs $10 \mu \mathrm{m}$ ); nerve ring located more posteriorly (53-60 vs $50 \%$ of total neck length); sometimes presence of small anterior uterine sac about one-fourth to one-third midbody diameter long (vs anterior sac completely absent) and slightly shorter prerectum (2.0-3.1 vs 3.0-4.0 times anal body diameter). These slight differences are considered as intraspecific variability. This species is reported here for the first time from the India.

\section{Basirotyleptus ethiopicus Siddiqi, 1970}

Fig. 4, Table 4

Basirotyleptus ethiopicus Siddiqi, 1970: 205-206

Basirotyleptus ethiopicus - Goseco et al. 1974: 11, 20.

\section{Material examined}

INDIA - Kerala State - 7 q 9 ; Palakkad district, Silent Valley National Park; $11^{\circ} 03^{\prime} 49.6^{\prime \prime}$ N, 76²'17.4" E; 5-15 cm depth; 26 Oct. 2017; soil samples collected from around the roots of forest trees (unidentified); slides reference number AMU/ZD/NC/Basirotyleptus ethiopicus/1-5.

\section{Description}

\section{Female}

Small sized nematodes, slightly curved ventrad upon fixation; tapering gradually towards both extremities but more so towards anterior end. Cuticle with two distinct layers, $1.0-1.5 \mu \mathrm{m}$ thick at anterior region, 2.0-2.5 $\mu \mathrm{m}$ at midbody and $2.5-3.0 \mu \mathrm{m}$ on tail. Outer cuticle thin with transverse striation, inner layer 

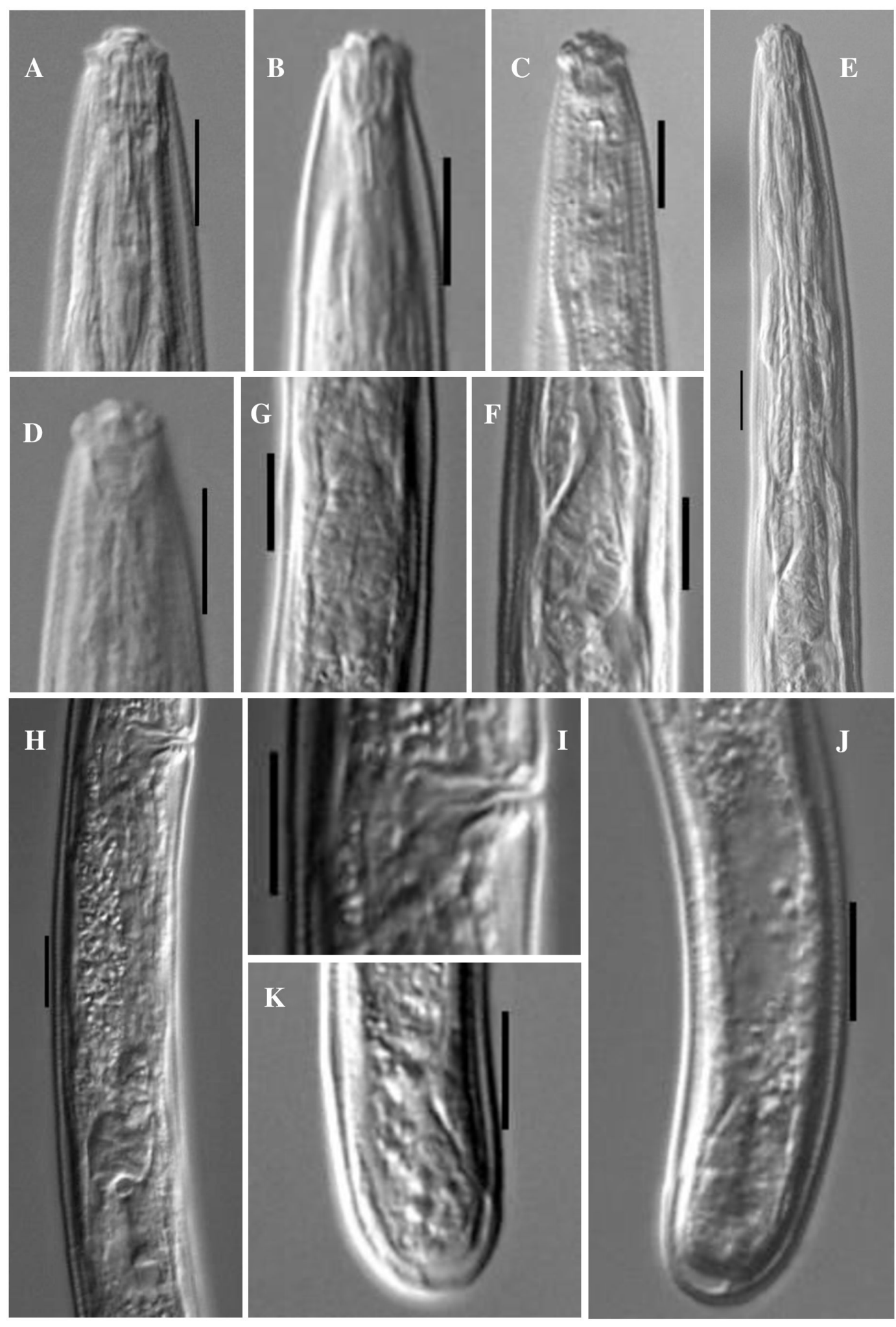

Fig. 4. Basirotyleptus ethiopicus Siddiqi, 1970, q (AMU/ZD/NC/Basirotyleptus ethiopicus/1-5) (LM photographs). A-C. Anterior region. D. Anterior region showing amphid. E. Pharyngeal region. F-G. Pharyngeal bulb. H. Genital system. I. Vulval region. J. Posterior region. K. Posterior end. Scale bars $=10 \mu \mathrm{m}$. 
Table 4. Measurements of Basirotyleptus ethiopicus Siddiqi, 1970. All measurements are in $\mu \mathrm{m}$ and in the form: mean \pm s.d. (range).

\begin{tabular}{lc}
\hline Characters & Females \\
\hline $\mathrm{n}$ & 7 \\
$\mathrm{~L}$ & $439.8 \pm 51.9(388-500)$ \\
Body diameter at neck base & $17.7 \pm 1.2(16.5-20.5)$ \\
Body diameter at mid body & $19.6 \pm 1.2(18.5-22.5)$ \\
Body diameter at anus & $13.3 \pm 1.0(12.5-15.5)$ \\
$\mathrm{a}$ & $21.9 \pm 1.2(20.8-24.8)$ \\
$\mathrm{b}$ & $4.3 \pm 0.46(3.8-5.3)$ \\
$\mathrm{c}$ & $45.2 \pm 3.3(42.2-52.0)$ \\
$\mathrm{c}$ & $0.71 \pm 0.03(0.70-0.80)$ \\
$\mathrm{V}$ & $40.1 \pm 2.3(36.9-43.6)$ \\
G2 & $20.2 \pm 3.2(16.0-24.7)$ \\
Lip region diameter & $6.4 \pm 0.49(6.0-7.5)$ \\
Lip region height & $3.1 \pm 0.24(3.0-3.5)$ \\
Amphidial aperture & $3.1 \pm 0.22(3.0-3.5)$ \\
Odontostyle length & $10.1 \pm 0.85(8.5-10.5)$ \\
Odontophore length & $11.3 \pm 0.55(10.5-12.0)$ \\
Total stylet length & $21.4 \pm 1.2(19.5-23.0)$ \\
Guiding ring from anterior end & $7.7 \pm 0.88(7.0-10)$ \\
Nerve ring from anterior end & $58.9 \pm 2.1(54-61)$ \\
Neck length & $100.2 \pm 4.3(94-105)$ \\
Expanded part of pharynx & $15.2 \pm 0.88(14-17)$ \\
Cardia length & $4.6 \pm 0.68(4.0-6.0)$ \\
Posterior genital branch & $90.8 \pm 16.5(68-113)$ \\
Vagina length & $9.6 \pm 0.81(8.5-10.5)$ \\
Vulva from anterior end & $179.0 \pm 12.9(167-206)$ \\
Prerectum length & $32.0 \pm 2.9(27-37)$ \\
Rectum length & $14.4 \pm 1.8(12.5-18.5)$ \\
Tail length & $9.5 \pm 0.68(9.0-11)$ \\
\hline &
\end{tabular}

thick, distinctly striated, loose, its outline irregular, with distinct radial refractive elements. Lateral chords occupying about $30-35 \%$ of midbody diameter. Lateral body pores distinct; $1-2$ in neck region; 1-2 from pharyngeal base to vulva; 4-7 in post-vulval region. Dorsal and ventral body pores indistinct. Lip region cap-like, offset by slight constriction, 1.8-2.1 times as wide as high or about one-third to two-fifths of the body diameter at neck base. Lips rounded, amalgamated; inner part elevated, forming a perioral disc. Labial and cephalic papillae distinct but not interfering with labial contour. Amphids duplex, stirrup-shaped, their aperture about one-half to three-fifths as wide as lip region diameter. Stoma 
a long, slender truncate cone, slightly sclerotized in the perioral region. Odontostyle very slender, solid, thin needle-like, 1.4-1.8 times the lip region diameter long. Odontophore simple, sclerotized, about 1.0-1.2 times the odontostyle length. Guiding ring simple, refractive, at 1.0-1.3 times the lip region diameter from anterior end. Pharynx consisting of a slender anterior part, expanding abruptly into a short, pear-shaped basal bulb, with a perceptible thickening at the posterior part of its inner lining, occupying about $13-16 \%$ of total neck length. Nerve ring at $55-62 \%$ of neck length from anterior end. Cardia short, rounded to conoid, about one-fourth to one-third of the corresponding body diameter long.

Genital system monodelphic-opisthodelphic. Ovary reflexed, measuring 36-88 $\mu \mathrm{m}$; oocytes arranged in single row except near tip. Oviduct joining the ovary subterminally, measuring 30-57 $\mu \mathrm{m}$, consisting of a slender distal portion and a weakly developed pars dilatata. Oviduct-uterus junction indistinct. Uterus short and tubular, measuring 21-32 $\mu \mathrm{m}$. Anterior genital branch completely absent. Sperm cell absent. Vagina cylindrical, extending inwards, $8.5-10.5 \mu \mathrm{m}$ or about two-fifths to one-half (45-55\%) of midbody diameter; pars proximalis vaginae 5.0-7.0 $\times 3.0-4.0 \mu \mathrm{m}$, encircled by circular muscles; pars distalis vaginae 3.0-4.0 $\mu \mathrm{m}$ with slightly curved walls; pars refringens absent. Vulva apparently a transverse slit. Prerectum 2.0-2.9 and rectum 0.9-1.4 times anal body diameter long. Tail short, rounded to hemispheroid, $0.7-0.8$ times anal body diameter long, with a pair of caudal pores on each side.

\section{Male \\ Not found.}

\section{Remarks}

Siddiqi (1970) described B. ethiopicus from the Malawi. Goseco et al. (1974) in their revision of the genus Basirotyleptus made a detailed study of the type material and added a population from Indiana. The morphometrics of present populations conform well with the type population as well as Indiana population except in having slightly wider lip region $(6.0-7.5$ vs $5.0-6.0 \mu \mathrm{m})$; narrower lateral chords (30-35\% vs more than $50 \%$ of mid body diameter) and slight differently shaped cardia (rounded to conoid vs rounded). These slight differences are considered as intraspecific variability. This species is reported here for the first time from the India.

In the presence of labial disc, this species closely resembles $B$. nemoralis Siddiqi, 1970 except in having a comparatively robust body $(\mathrm{a}=20-25$ vs $27-33)$; shorter pharyngeal bulb (about one vs two corresponding body diameter long); absence of anterior uterine sac (vs present) and differently shaped tail (rounded to hemispheroid vs obtusely rounded).

Basirotyleptus acus Goseco, Ferris \& Ferris, 1974

Fig. 5, Table 5

Basirotyleptus acus Goseco et al., 1974: 12, 14.

Basirotyleptus pini - Furstenberg 1980: 153-155.

\section{Material examined}

INDIA - Kerala State - 11 $q$; Palakkad district, Silent Valley National Park; $11^{\circ} 03^{\prime} 49.6^{\prime \prime}$ N, 76 32'17.4" E; 5-15 cm depth; 26 Oct. 2017; soil samples collected from around the roots of forest trees (unidentified); slides reference number AMU/ZD/NC/Basirotyleptus acus/1-4. - Tamil Nadu State •

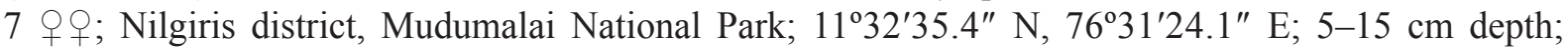
14 Nov. 2016; soil samples collected from around the roots of shrubs (unidentified); slides reference number AMU/ZD/NC/Basirotyleptus acus/5-8. 

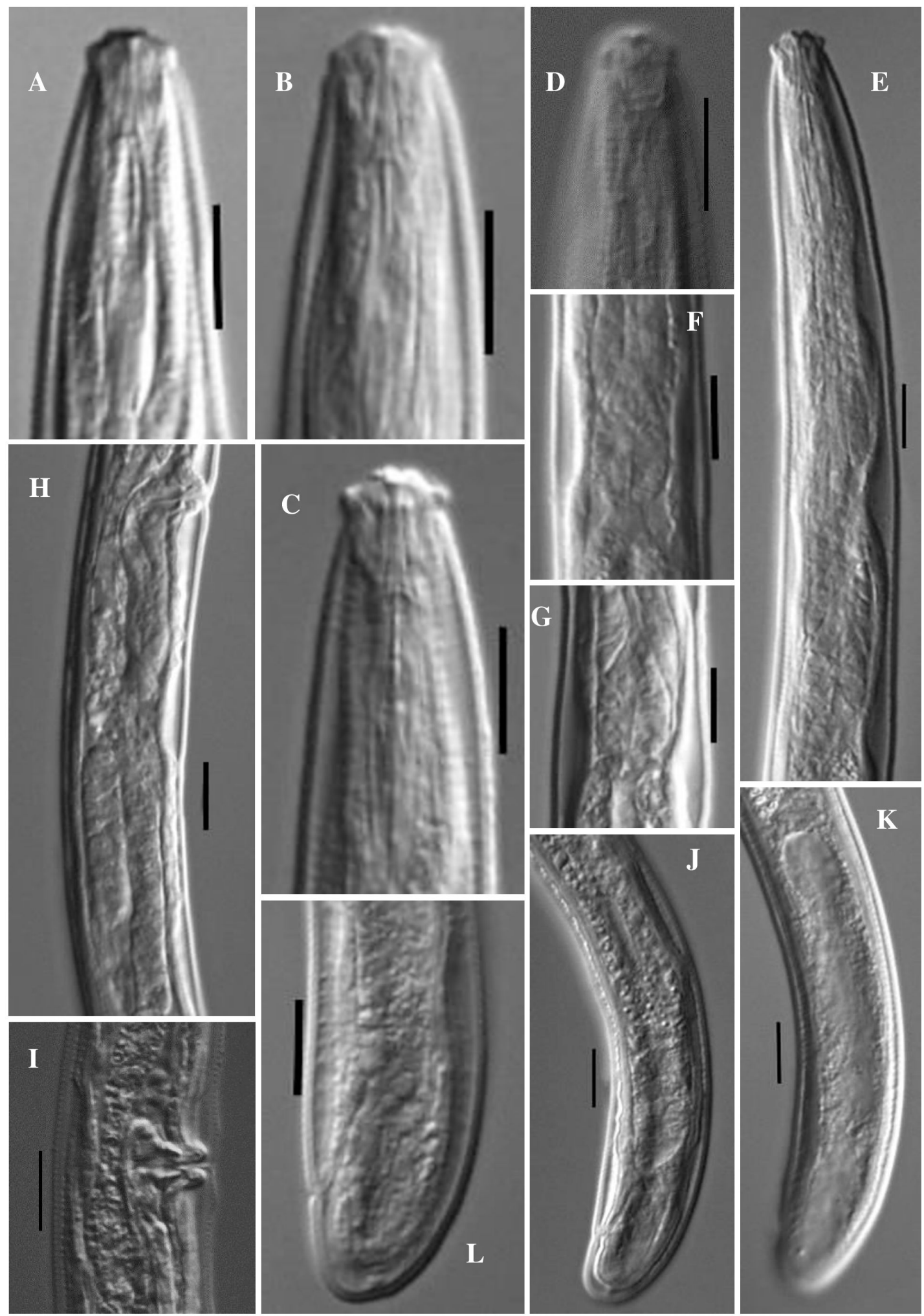

Fig. 5. Basirotyleptus acus Goseco, Ferris \& Ferris, 1974, ㅇ (AMU/ZD/NC/Basirotyleptus acus/1-4) (LM photographs). A-C. Anterior region. D. Anterior region showing amphid. E. Pharyngeal region. F-G. Pharyngeal bulb. H. Genital system. I. Vulval region. J-K. Posterior region. L. Posterior end. Scale bars $=10 \mu \mathrm{m}$. 
Table 5. Measurements of Basirotyleptus acus Goseco, Ferris \& Ferris, 1974. All measurements are in $\mu \mathrm{m}$ and in the form: mean \pm s.d. (range).

\begin{tabular}{|c|c|c|}
\hline Localities & Mukkali population & Modumalai population \\
\hline Characters & Females & Females \\
\hline $\mathrm{n}$ & 11 & 7 \\
\hline $\mathrm{L}$ & $486.1 \pm 50.5(391-552)$ & $530.0 \pm 40.6(471-594)$ \\
\hline Body diameter at neck base & $18.9 \pm 0.98(17.5-20.5)$ & $18.9 \pm 0.68(18.5-20.5)$ \\
\hline Body diameter at mid body & $20.9 \pm 1.1(19.5-23.5)$ & $21.0 \pm 0.98(19.5-22.5)$ \\
\hline Body diameter at anus & $13.9 \pm 1.5(11.5-16.5)$ & $13.5 \pm 0.58(12.5-14.5)$ \\
\hline $\mathrm{a}$ & $23.1 \pm 1.7(20.0-25.6)$ & $24.7 \pm 2.2(21.3-28.7)$ \\
\hline $\mathrm{b}$ & $4.8 \pm 0.38(4.2-5.4)$ & $4.7 \pm 0.18(4.5-5.0)$ \\
\hline $\mathrm{c}$ & $48.9 \pm 4.5(40.5-54.7)$ & $48.3 \pm 2.6(44.5-53.4)$ \\
\hline$c^{\prime}$ & $0.72 \pm 0.07(0.61-0.84)$ & $0.79 \pm 0.06(0.64-0.85)$ \\
\hline $\mathrm{V}$ & $36.9 \pm 1.2(35.5-39.8)$ & $36.9 \pm 1.6(35.7-41.0)$ \\
\hline G2 & $20.5 \pm 3.1(13.3-24.5)$ & $18.2 \pm 2.4(14.6-21.5)$ \\
\hline Lip region diameter & $7.2 \pm 0.32(7.0-8.0)$ & $7.6 \pm 0.34(7.0-8.0)$ \\
\hline Lip region height & $3.3 \pm 0.20(3.0-3.5)$ & $3.6 \pm 0.24(3.5-4.0)$ \\
\hline Amphidial aperture & $3.5 \pm 0.22(3.5-4.0)$ & $3.8 \pm 0.18(3.5-4.0)$ \\
\hline Odontostyle length & $11.5 \pm 0.26(10-11)$ & $11.0 \pm 0.54(10.5-11.5)$ \\
\hline Odontophore length & $11.4 \pm 0.58(11-12)$ & $12.0 \pm 0.88(11-13)$ \\
\hline Total stylet length & $22.2 \pm 0.73(21-23)$ & $23.0 \pm 1.3(21.5-24.5)$ \\
\hline Guiding ring from anterior end & $9.0 \pm 0.39(8.5-9.5)$ & $9.6 \pm 0.21(9.0-10)$ \\
\hline Nerve ring from anterior end & $57.8 \pm 2.0(54-61)$ & $62.8 \pm 1.6(60-65)$ \\
\hline Neck length & $99.6 \pm 4.4(93-106)$ & $111.3 \pm 4.6(102-119)$ \\
\hline Expanded part of pharynx & $15.5 \pm 0.92(15-18)$ & $18.9 \pm 0.83(17-20)$ \\
\hline Cardia length & $4.8 \pm 0.14(4.5-5.0)$ & $4.4 \pm 0.71(3.0-5.0)$ \\
\hline Anterior genital branch & $4.9 \pm 0.61(4.0-6.0)$ & $5.8 \pm 0.42(5.0-6.5)$ \\
\hline Posterior genital branch & $100.8 \pm 13.5(70-117)$ & $97.7 \pm 9.1(84-112)$ \\
\hline Vaginal length & $10.0 \pm 0.76(8.5-10.5)$ & $10.8 \pm 0.57(10.0-11.5)$ \\
\hline Vulva from anterior end & $179.4 \pm 19.1(139-201)$ & $199.6 \pm 12.1(179-213)$ \\
\hline Prerectum length & $42.7 \pm 5.0(38-53)$ & $42.7 \pm 3.1(39-49)$ \\
\hline Rectum length & $15.1 \pm 1.7(13.5-17.5)$ & $17.0 \pm 0.97(15.5-18.5)$ \\
\hline Tail length & $9.9 \pm 1.2(8.0-11.5)$ & $10.7 \pm 0.98(9.0-12)$ \\
\hline
\end{tabular}




\section{Description}

\section{Female}

Small sized nematodes, slightly curved ventrad or open C-shaped upon fixation; body cylindrical, tapering gradually towards both extremities but more so towards the anterior end. Cuticle with two distinct layers, $1.0-1.5 \mu \mathrm{m}$ thick at anterior region, $1.5-2.0 \mu \mathrm{m}$ at midbody and $2.0-2.5 \mu \mathrm{m}$ on tail. Outer cuticle thin, with fine transverse striations; inner layer thick, striated, loose, its outline irregular, with distinct radial refractive elements. Lateral chords occupying about $28-35 \%$ of midbody diameter. Lateral body pores distinct; $1-3$ in neck region; $1-2$ from pharyngeal base to vulva and 3-8 post-vulval region. Dorsal and ventral body pores indistinct. Lip region cap-like, offset by constriction, 2.0-2.3 times as wide as high or about one-third to two-fifths of the body diameter at neck base. Lips rounded, amalgamated; inner part slightly elevated. Labial and cephalic papillae distinct but not interfering with labial contour. Amphids duplex, stirrup-shaped, their aperture about one-half to three-fifths as wide as lip region diameter. Stoma a long, slender truncate cone, slightly sclerotized in the perioral region. Odontostyle very slender, solid, thin needle-like, sometimes slightly dorsally bent, 1.2-1.6 times the lip region diameter long. Odontophore simple, sclerotized, about 1.0-1.1 times the odontostyle length. Guiding ring simple, refractive, at 1.2-1.4 times the lip region diameter from anterior end. Pharynx consisting of a slender and slightly muscular anterior part, expanding gradually into a short pear-shaped basal bulb, with a perceptible thickening at the posterior part of its inner lining, occupying about 14$18 \%$ of total neck length. Nerve ring at $51-60 \%$ of neck length from anterior end. Cardia rounded to conoid, about one-fifth to one-fourth of the corresponding body diameter long.

Genital system monodelphic-opisthodelphic. Ovary reflexed, measuring 42-89 $\mu \mathrm{m}$; oocytes arranged in single row except near tip. Oviduct joining the ovary subterminally, measuring 44-63 $\mu \mathrm{m}$, consisting of a slender distal portion and a well-developed pars dilatata. Oviduct-uterus junction marked by weak sphincter. Uterus short and slender tube without any specialization, measuring 17-30 $\mu \mathrm{m}$. Anterior genital branch usually absent or reduced to a very small sac, about one-fifth to one-third midbody diameter long. Sperm cell absent. Vagina cylindrical, extending slight posteriorly, 8.5-11.5 $\mu \mathrm{m}$ or about two-fifths to one-half (40-52\%) of midbody diameter; pars proximalis vaginae 5.5-7.5 $\times 4.0-6.0 \mu \mathrm{m}$, encircled by circular muscles; pars distalis vaginae $3.5-4.5 \mu \mathrm{m}$ with slightly curved walls; pars refringens absent. Vulva apparently a transverse slit. Prerectum $2.5-3.8$ and rectum $0.9-1.3$ times anal body diameter long. Tail short, rounded to conoid, $0.6-0.8$ times anal body diameter long, with a pair of caudal pores on each side, a distinct terminal pore also present.

\section{Male}

Not found.

\section{Remarks}

Goseco et al. (1974) described this species from the Indiana. The morphometrics of present populations conform well with the type population except in having a slightly longer odontostyle (10.0-11.5 vs $8 \mu \mathrm{m})$, slightly shorter odontophore (11-13 vs $14.4 \mu \mathrm{m})$; shorter pharyngeal bulb (15-20 vs $22 \mu \mathrm{m})$; longer vagina (8.5-11.5 vs $13 \mu \mathrm{m})$ and presence of anterior uterine sac in some specimens (vs anterior uterine sac absent). This species is reported here for the first time from India.

During the present study, two populations representing eighteen specimens were collected from the Western Ghats, India. Although in some specimens of the present populations a very small anterior uterine sac was present, other morphometric values completely overlapped to with those in B. acus, and therefore these specimens are considered as B. acus.

Furstenberg (1980) redescribed B. pini Siddiqi \& Khan, 1965 based on two populations comprising twenty eight females from Australia and mentioned that Australian specimens correspond well with 
type population of $B$. pini except for the absence of anterior uterine sac in some specimens. Some doubt exists on the correct identity of the Australian population as it shows some morphological differences i.e., differently shaped odontostyle (odontostyle very slender, thin needle-like vs slender, simple needle-like); differently shaped lip region (lip region low, flat, offset by slight constriction vs lip region comparatively higher, angular, offset by deep constriction), labial papillae not interfering with labial contour (vs labial papillae interfering with labial contour, forming a liplets-like structure), and absence of anterior uterine sac in some specimens (vs anterior uterine present in every specimen). The morphometrics of Furstenberg (1980) population is quite comparable to B. acus except in the presence of anterior uterine sac in some specimens (vs absent in the type population). With the addition of present populations, which have specimens both with or without sac, B. pini apud Furstenberg, 1980 is considered here as $B$. acus.

Basirotyleptus minutus Khan, 1987

Figs 6-7, Table 6

Basirotyleptus minutus Khan, 1987: 177-179.

\section{Material examined}

INDIA - Karnataka State • 2 우; Kodagu district, Bhagamandala; $12^{\circ} 23^{\prime} 29.1^{\prime \prime}$ N, $75^{\circ} 31^{\prime} 50.0^{\prime \prime}$ E; 5-15 cm depth; 8 Nov. 2016; soil samples collected from around the roots of shrubs and forest trees (unidentified); slides reference number AMU/ZD/NC/Basirotyleptus minutus/1.

\section{Description}

\section{Female}

Small sized nematodes, slightly curved ventrad upon fixation; body cylindrical, tapering gradually towards both extremities but more so towards the anterior end. Cuticle with two distinct layers, $1.0 \mu \mathrm{m}$ thick at anterior region, $1.5 \mu \mathrm{m}$ at midbody and $2.0-2.5 \mu \mathrm{m}$ on tail. Outer cuticle thin, with fine transverse striations; inner layer thick, finely striated, loose, with radial refractive elements. Lateral chords occupying about $26-30 \%$ of midbody diameter. Lateral, dorsal and ventral body pores indistinct. Lip region cap-like, offset by constriction, 2.3 times as wide as high or about one-third of the body diameter at neck base. Lips rounded, amalgamated, slightly angular; inner part slightly elevated. Amphids duplex, cup-shaped, their aperture about one-half to three-fifths as wide as lip region diameter. Stoma a long, slender truncate cone, slightly sclerotized in the perioral region. Odontostyle slender, solid, needlelike, 1.4 times the lip region diameter long. Odontophore simple, sclerotized, with basal flanges, about 1.3-1.4 times the odontostyle length. Guiding ring simple, refractive, at 1.3 times the lip region diameter from anterior end. Pharynx consisting of a slender anterior part, expanding abruptly into a short pyriform bulb, with a perceptible thickening at the posterior part of its inner lining, occupying about $18 \%$ of total neck length. Nerve ring at $52-55 \%$ of neck length from anterior end. Cardia rounded to hemispheroid, about one-fourth of the corresponding body diameter long.

Genital system monodelphic-opisthodelphic. Ovary reflexed, measuring 43-59 $\mu \mathrm{m}$; oocytes arranged in single row except near tip. Oviduct joining the ovary subterminally, measuring 55-84 $\mu \mathrm{m}$, consisting of a slender distal portion and a well-developed pars dilatata. Oviduct-uterus junction marked by distinct sphincter. Uterus a short tube with wide lumen, measuring 27-30 $\mu \mathrm{m}$. Anterior genital branch reduced to a very small sac, about one-fifth midbody diameter long. Sperm cell absent. Vagina cylindrical, extending inwards, $10.0-10.5 \mu \mathrm{m}$ or about one-half (50-55\%) of midbody diameter; pars proximalis vaginae $6.5 \times 4.5-5.0 \mu \mathrm{m}$, encircled by circular muscles; pars distalis vaginae $4.0 \mu \mathrm{m}$ with slightly curved walls; pars refringens absent. Vulva apparently a transverse slit. Prerectum 3.1-3.2 and rectum 0.9-1.0 times anal body diameter long. Tail short, rounded to conoid, 0.8 times anal body diameter long, with a pair of caudal pores on each side. 


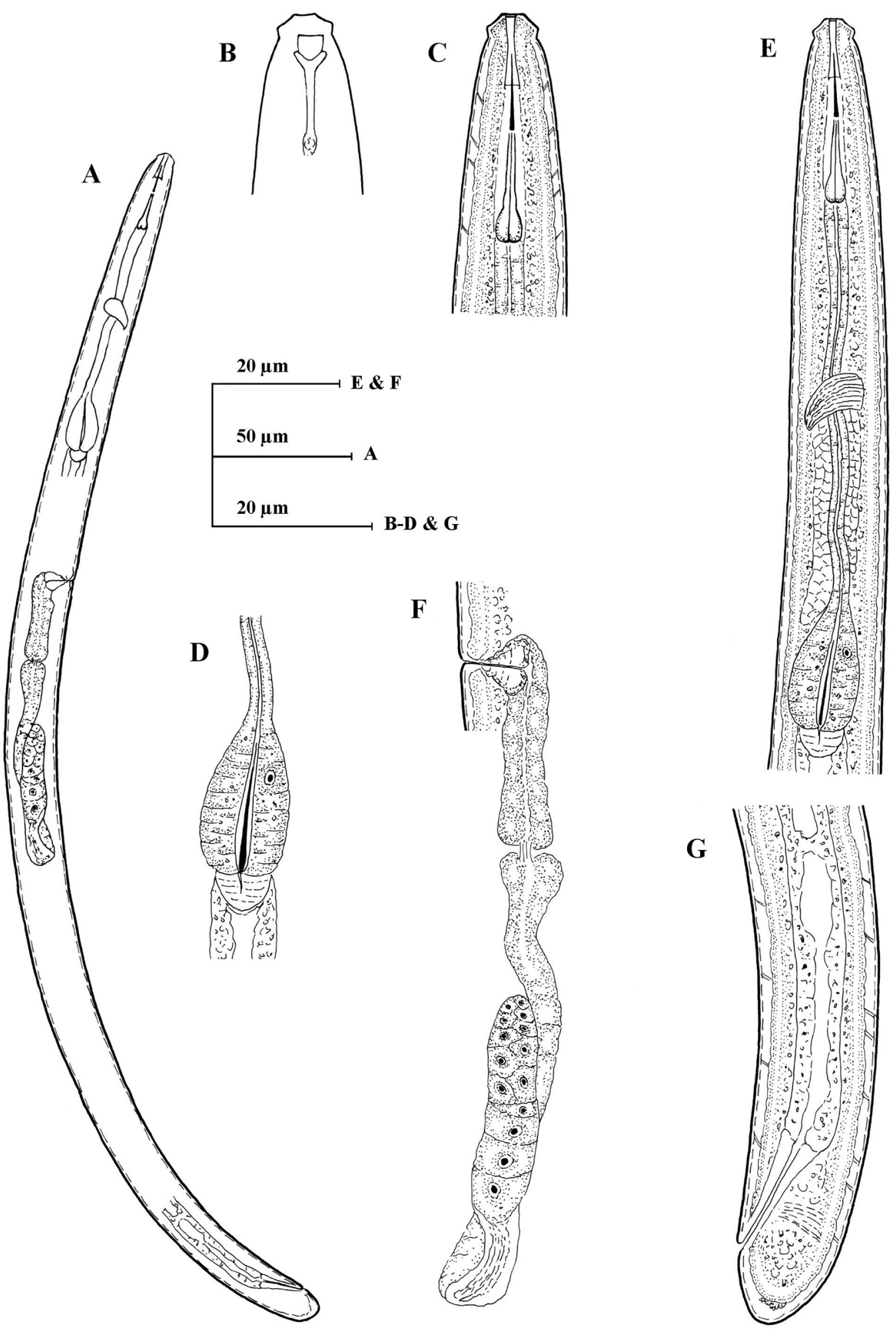

Fig. 6. Basirotyleptus minutus Khan, 1987, ㅇ (AMU/ZD/NC/Basirotyleptus minutus/1). A. Entire specimen. B. Anterior region showing amphid. C. Anterior region. D. Pharyngeal bulb. E. Pharyngeal region. F. Genital system. G. Posterior region. 

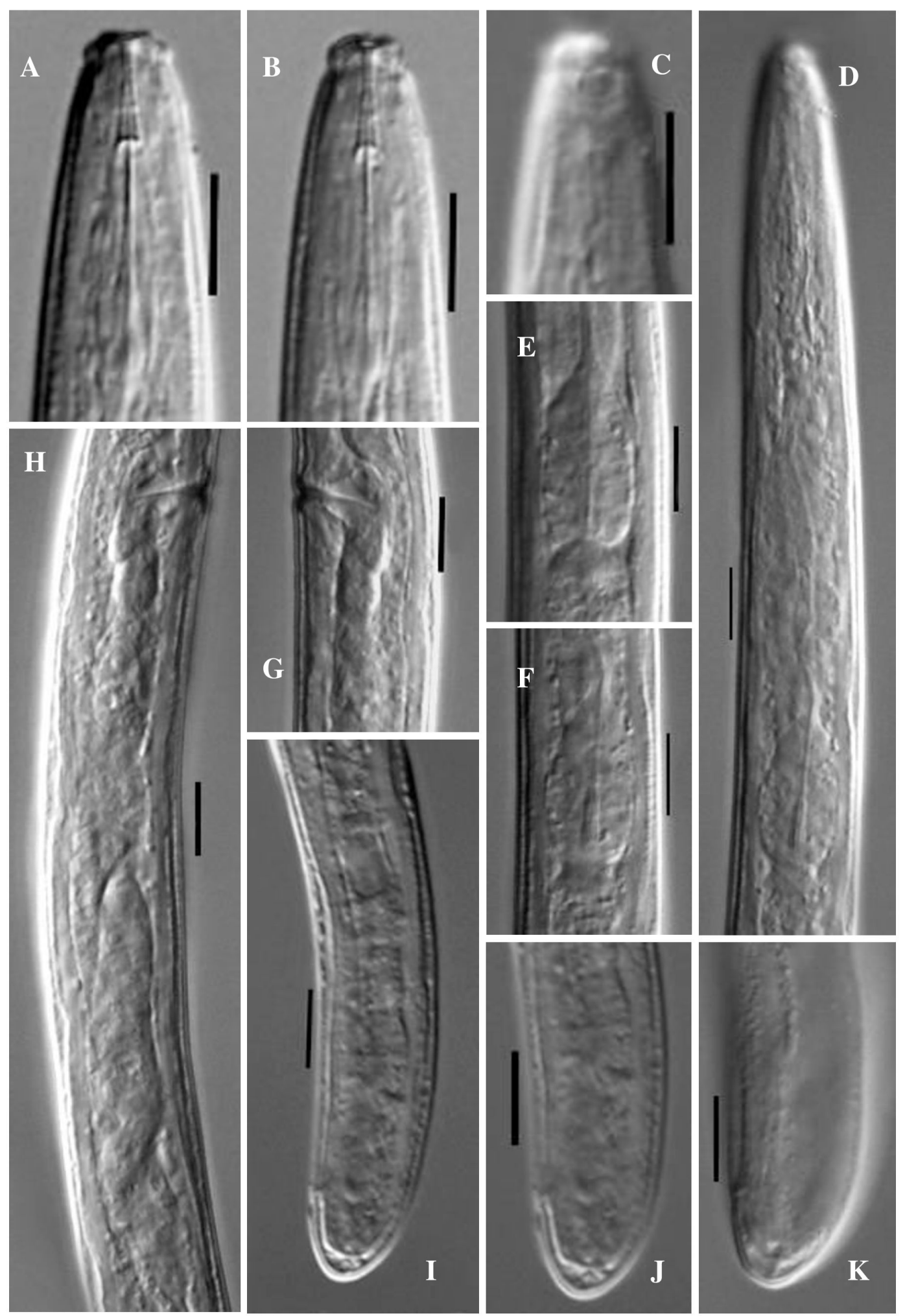

Fig. 7. Basirotyleptus minutus Khan, 1987, \& (AMU/ZD/NC/Basirotyleptus minutus/1) (LM photographs). A-B. Anterior region. C. Anterior region showing amphid. D. Pharyngeal region. E-F. Pharyngeal bulb. G. Vulval region. H. Genital system. I. Posterior region. J-K. Posterior end. Scale bars $=10 \mu \mathrm{m}$. 
Table 6. Measurements of Basirotyleptus minutus Khan, 1987. All measurements are in $\mu \mathrm{m}$.

\begin{tabular}{|c|c|}
\hline Characters & Females \\
\hline $\mathrm{n}$ & 2 \\
\hline $\mathrm{L}$ & 446,486 \\
\hline Body diameter at neck base & $17.0,18.5$ \\
\hline Body diameter at mid body & $18.5,19.5$ \\
\hline Body diameter at anus & $12.5,12.5$ \\
\hline $\mathrm{a}$ & $24.0,24.8$ \\
\hline $\mathrm{b}$ & $4.0,4.1$ \\
\hline $\mathrm{c}$ & 45,49 \\
\hline$c^{\prime}$ & $0.8,0.8$ \\
\hline $\mathrm{V}$ & $35.1,33.7$ \\
\hline G1 & $0.7,0.8$ \\
\hline G2 & $20.6,26.2$ \\
\hline Lip region diameter & $7.0,7.0$ \\
\hline Lip region height & $3.0,3.0$ \\
\hline Amphidial aperture & $3.5,4.0$ \\
\hline Odontostyle length & 10,10 \\
\hline Odontophore length & 13,14 \\
\hline Total stylet length & 23,24 \\
\hline Guiding ring from anterior end & $9.0,9.0$ \\
\hline Nerve ring from anterior end & 57,64 \\
\hline Neck length & 111,117 \\
\hline Expanded part of pharynx & 19,20 \\
\hline Cardia length & $4.0,4.0$ \\
\hline Anterior genital branch & $4.0,4.0$ \\
\hline Posterior genital branch & 94,130 \\
\hline Vagina length & $10.5,10.0$ \\
\hline Vulva from anterior end & 156,163 \\
\hline Prerectum length & 39,41 \\
\hline Rectum length & 12,13 \\
\hline Tail length & 10,10 \\
\hline
\end{tabular}




\section{Male}

Not found.

\section{Remarks}

Khan (1987) described Basirotyleptus minutus from Tamil Nadu, India. The morphometrics of present specimens conform well with the type population except in having differently shaped amphids (duplex, cup-shaped vs simple, stirrup-shaped) and slightly longer pharyngeal bulb (19-20 vs $16 \mu \mathrm{m})$. In original description of $B$. minutus, the size of odontostyle $(10-14 \mu \mathrm{m})$ and odontophore $(8.0-10.0 \mu \mathrm{m})$ does not correspond with the figure (Khan 1987: fig. 2b, e). The figure depicts the odonotostyle as shorter than the odontophore which is generally true with other Basirotyleptus species. There might be error in his measurements. In our present specimens the length of odontostyle $(10 \mu \mathrm{m})$ is shorter than odontophore (13-14 $\mu \mathrm{m})$ with a combined length of 23-24 $\mu \mathrm{m}$, which overlaps with type population $(18-24 \mu \mathrm{m})$. However, in the other characters the present population agrees well with the type population.

In the presence of flanged odontophore, this species closely resembles Basirotyleptus nindei Siddiqi, 1970 except in having slightly differently shaped lip region (lips slightly angular and labial papillae not distinct vs lips more angular and labial papillae distinct); differently shaped amphids (duplex, cupshaped vs simple, stirrup-shaped) and comparatively shorter tail (10.0 vs $11.0-13.5 \mu \mathrm{m}, \mathrm{c}^{\prime}=0.8 \mathrm{vs}$ $1.0-1.2)$.

Basirotyleptus conicaudatus sp. nov.

urn:1sid:zoobank.org:act:25B540AE-3BF1-43F8-865C-7342E11514F8

Figs $8-9$, Table 7

\section{Diagnosis}

Basirotyleptus conicaudatus sp. nov. is characterized by having robust body, $0.42-0.44 \mathrm{~mm}$ long; lip region cap-like, offset by deep constriction, lips rounded, inner part elevated; odontostyle 9.5-10.0 $\mu \mathrm{m}$ long, odontophore 11.0-12.0 $\mu \mathrm{m}$ long and total stylet length $21.0-22.0 \mu \mathrm{m}$; pharynx with a slender anterior part, expanding abruptly into a short pear-shaped basal bulb, occupying about $14-15 \%$ of total neck length; female genital system monodelphic-opisthodelphic; anterior genital branch a small sac, measuring $15-20 \mu \mathrm{m}$ or $0.7-0.9$ times midbody diameter long; tail convex-conoid with acute terminus, 1.2-1.3 times anal body diameter long; male with $20 \mu \mathrm{m}$ long spicules, $5.0 \mu \mathrm{m}$ long lateral guiding pieces and a single ventromedian supplement.

\section{Etymology}

The new species is named Basirotyleptus conicaudatus sp. nov. because of its conoid tail.

\section{Material examined}

\section{Holotype}

INDIA • O ; Kerala State; Thrissur district, Chalakudy; $10^{\circ} 18^{\prime} 03.6^{\prime \prime}$ N, 76 26'27.6" E; 5-15 cm depth; 27 Oct. 2017; roots of shrubs (unidentified); slide reference number AMU/ZD/NC/Basirotyleptus conicaudatus/1.

\section{Paratypes}

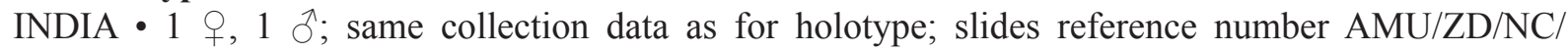
Basirotyleptus conicaudatus/2. 


\section{Type habitat and locality}

Soil samples collected from around the roots of shrubs (unidentified) from Chalakudy, Thrissur, Kerala State.

\section{Description}

\section{Female}

Small sized nematodes, curved ventrad upon fixation; body cylindrical, tapering gradually towards both extremities but more so towards the anterior end. Cuticle with two distinct layers, $1.0 \mu \mathrm{m}$ thick at anterior region, $1.5 \mu \mathrm{m}$ at midbody and $2.0 \mu \mathrm{m}$ on tail. Outer cuticle thin, smooth to finely transversaly striated; inner layer thick, loose, finely striated, radial refractive elements distinct. Lateral chords occupying about $28-30 \%$ of midbody diameter. Lateral, dorsal and ventral body pores indistinct. Lip region caplike, offset by constriction, 2.0-2.1 times as wide as high or about two-fifths of the body diameter at neck base. Lips rounded, amalgamated, inner part slightly elevated. Labial and cephalic papillae distinct but not interfering with labial contour. Amphids stirrup-shaped, their aperture about three-fifths as wide as lip region diameter. Stoma a long, slender truncate cone, slightly sclerotized in the perioral region. Odontostyle short, slender, solid, needle-like, 1.1-1.2 times the lip region diameter long. Odontophore simple, sclerotized, with basal flanges, about 1.2 times the odontostyle length. Guiding ring simple, refractive, at 0.9-1.0 times the lip region diameter from anterior end. Pharynx consisting of a slender anterior part, expanding abruptly into a short, pear-shaped basal bulb, with a perceptible thickening at the posterior part of its inner lining, occupying about $14-15 \%$ of total neck length. Nerve ring at $53-56 \%$ of neck length from anterior end. Cardia rounded to conoid, about one-fifth of the corresponding body diameter long.

Genital system monodelphic-opisthodelphic. Ovary reflexed, measuring 49-50 $\mu \mathrm{m}$; oocytes arranged in single row except near tip. Oviduct joining the ovary subterminally, measuring 53-60 $\mu \mathrm{m}$, consisting of a slender distal portion and a well-developed pars dilatata. Oviduct-uterus junction marked by distinct sphincter. Uterus short and wide tubular, measuring 15-17 $\mu \mathrm{m}$. Anterior genital branch reduced to small sac, 0.7-0.9 times midbody diameter. Vagina cylindrical, extending inwards, $9.0-9.5 \mu \mathrm{m}$ or about one-half (45-48\%) of midbody diameter; pars proximalis vaginae 5.5-6.0 $\times 4.0-4.5 \mu \mathrm{m}$, encircled by circular muscles; pars distalis vaginae 3.0-3.5 $\mu \mathrm{m}$ with slightly curved walls; pars refringens absent. Vulva apparently a transverse slit. Prerectum 2.8-3.2 and rectum 1.2 times anal body diameter long. Tail short, convex-conoid with acute terminus, 1.2-1.3 times anal body diameter long, with a pair of caudal pores on each side.

\section{Male}

General morphology similar to that of female except for posterior region being more ventrally curved. Genital system diorchic, testes opposed, sperm cell spindle-shaped. In addition to adcloacal pair at $6.5 \mu \mathrm{m}$ from cloacal aperture, there is single ventromedian supplement located beyond the range of spicules, $25 \mu \mathrm{m}$ from adcloacal pair. Spicules typically dorylaimoid, curved ventrad, slender, five times as long as wide and 1.4 times as long as cloacal body diameter, dorsal contour regularly convex, ventral contour bearing a moderately developed hump and hollow, curvature $135^{\circ}$, head occupying $22 \%$ of total spicules length, median pieces about ten times as long as wide or occupying $37 \%$ of the spicules maximum width, reaching the spicules tip, posterior end $2.5 \mu \mathrm{m}$ wide. Lateral guiding pieces distinct, rod-like, about 5.0 times as long as wide or about one-fourth of the spicules length. Prerectum 3.5 and rectum 1.5 times cloacal body diameter long. Tail short, convex-conoid with acute terminus, 1.2 times cloacal body diameter long, with a pair of caudal pores on each side. 

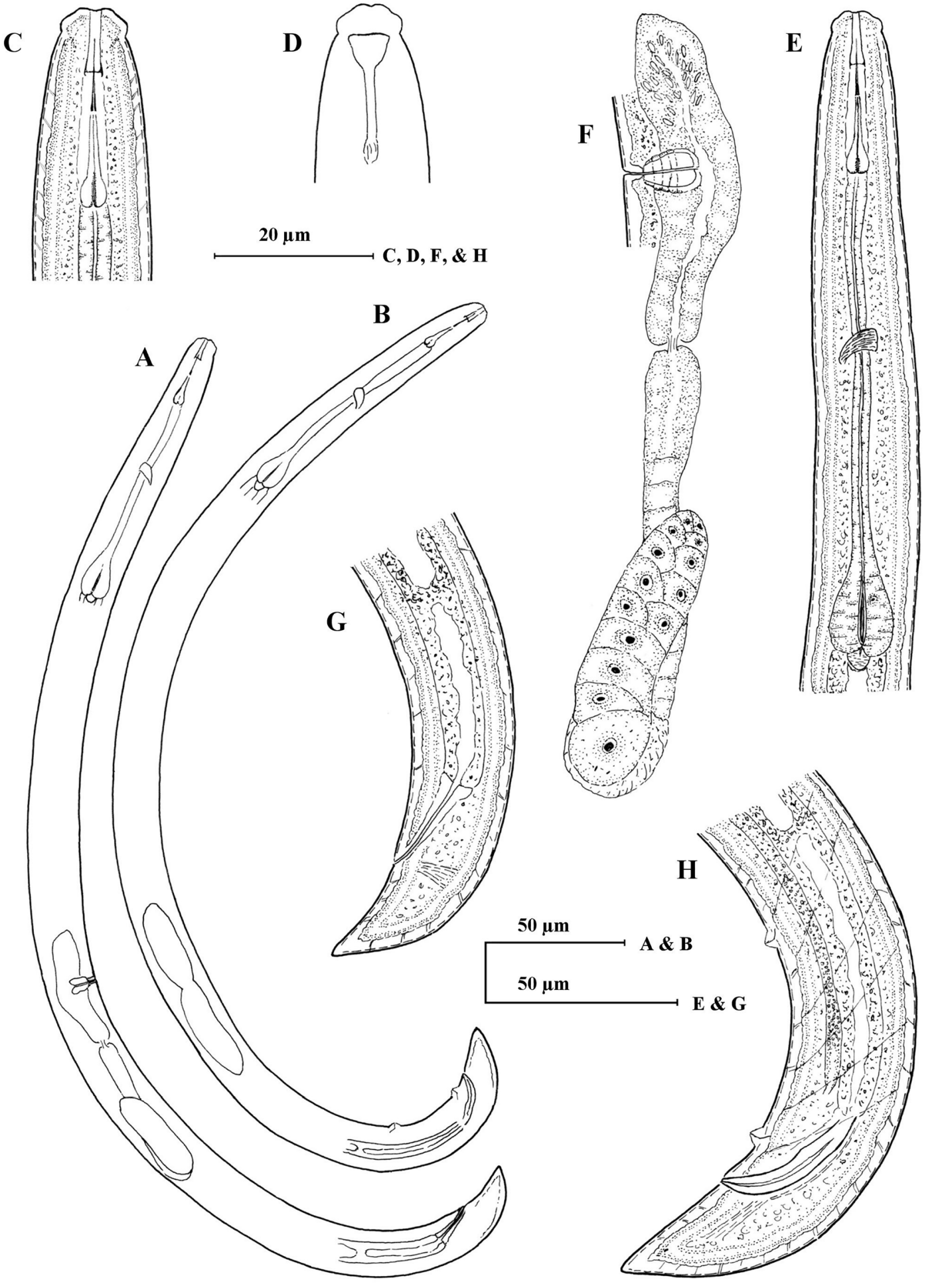

Fig. 8. Basirotyleptus conicaudatus sp. nov. A, C-G. Holotype, ㅇ (AMU/ZD/NC/Basirotyleptus conicaudatus/1). B, H. Paratype, ô (AMU/ZD/NC/Basirotyleptus conicaudatus/2). A. Entire female. B. Entire male. C. Female, anterior region. D. Female, anterior region showing amphid. E. Female, pharyngeal region. F. Female, genital system. G. Female, posterior region. H. Male, posterior region. 

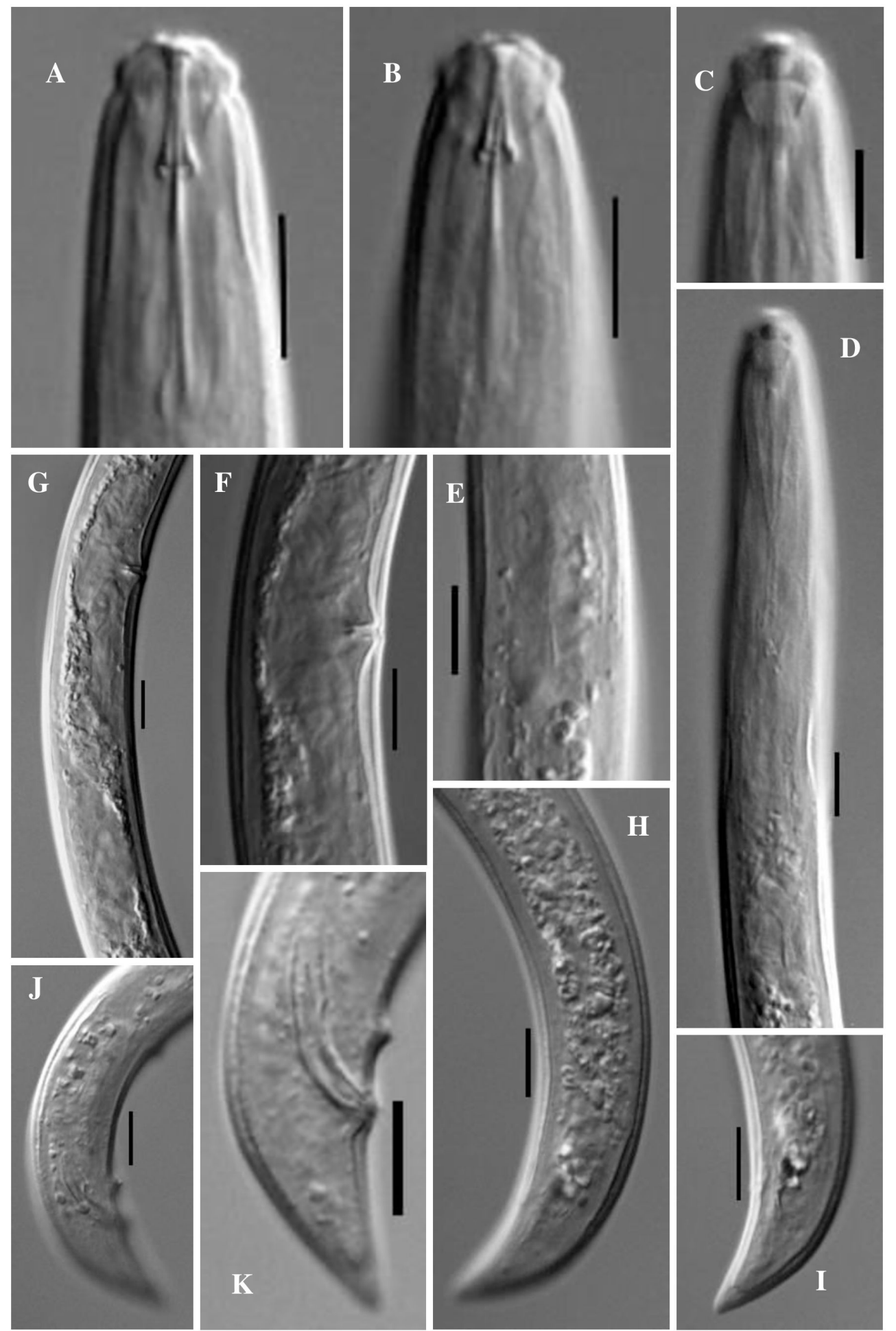

Fig. 9. Basirotyleptus conicaudatus sp. nov. (LM photographs). A, C-I. Holotype, $q$ (AMU/ZD/ $\mathrm{NC} /$ Basirotyleptus conicaudatus/1). B. Paratype 1, + (AMU/ZD/NC/Basirotyleptus conicaudatus/2). J-K. Paratype 2, ô (AMU/ZD/NC/Basirotyleptus conicaudatus/2). A-B. Female, anterior region. C. Female, anterior region showing amphid. D. Female, pharyngeal region. E. Female, pharyngeal bulb. F-G. Female, genital system. H. Female, posterior region. I. Female, posterior end. J-K. Male, posterior end. Scale bars $=10 \mu \mathrm{m}$. 
Table 7. Measurements of Basirotyleptus conicaudatus sp. nov. All measurements are in $\mu \mathrm{m}$.

\begin{tabular}{|c|c|c|c|}
\hline Characters & Holotype + & Paratype $q$ & Paratype $\delta^{\lambda}$ \\
\hline $\mathrm{n}$ & & 1 & 1 \\
\hline $\mathrm{L}$ & 442 & 427 & 423 \\
\hline Body diameter at neck base & 18 & 18.5 & 16.5 \\
\hline Body diameter at mid body & 19.5 & 19.5 & 18.5 \\
\hline Body diameter at anus & 13.5 & 13.0 & 13.5 \\
\hline $\mathrm{a}$ & 22.6 & 21.8 & 24.0 \\
\hline $\mathrm{b}$ & 4.3 & 4.4 & 4.0 \\
\hline $\mathrm{c}$ & 25.1 & 27.3 & 25.4 \\
\hline$c^{\prime}$ & 1.3 & 1.2 & 1.2 \\
\hline V & 55.3 & 58.0 & - \\
\hline G1 & 4.2 & 3.4 & - \\
\hline G2 & 21.0 & 20.4 & - \\
\hline Lip region diameter & 8.0 & 8.5 & 8.0 \\
\hline Lip region height & 4.0 & 4.0 & 4.0 \\
\hline Amphidial aperture & 5.0 & 5.0 & 5.0 \\
\hline Odontostyle length & 10 & 9.5 & 10 \\
\hline Odontophore length & 12 & 11.5 & 11 \\
\hline Total stylet length & 22 & 21 & 21 \\
\hline Guiding ring from anterior end & 8.5 & 8.0 & 8.5 \\
\hline Nerve ring from anterior end & 56 & 50 & 58 \\
\hline Neck length & 101 & 97 & 105 \\
\hline Expanded part of pharynx & 15 & 14 & 15 \\
\hline Cardia length & 4.0 & 4.0 & 4.0 \\
\hline Anterior genital branch & 20 & 15 & - \\
\hline Posterior genital branch & 87 & 93 & - \\
\hline Vagina length & 9.0 & 9.5 & - \\
\hline Vulva from anterior end & 245 & 247 & - \\
\hline Prerectum length & 37 & 41 & 48 \\
\hline Rectum length & 14 & 13 & 20 \\
\hline Tail length & 17 & 15.5 & 16.5 \\
\hline Spicules length & - & - & 20 \\
\hline Lateral guiding pieces & - & - & 5 \\
\hline Ventromedian supplements & - & - & 1 \\
\hline
\end{tabular}




\section{Remarks}

In the presence of a flanged odontophore and short anterior uterine sac, the new species comes close to B. syncheilus Siddiqi, 1995; B. siremps Siddiqi, 1995; B. nindei Siddiqi, 1970 and B. minutus Khan, 1987 but differs from $B$. syncheilus in having lip region offset by constriction (vs lip region continuous); lips elevated (vs lips not elevated, flat); shorter pharyngeal bulb (14-15 vs $19 \mu \mathrm{m}$ ); differently shaped tail (tail convex-conoid with acute terminus vs convex-rounded with hemispheroid terminus); lower c (25-27 vs 34-53) and slightly higher c' (1.2-1.3 vs $0.9-1.1)$ ratios; longer spicules (20 vs $15-16 \mu \mathrm{m})$ and presence of ventromedian supplements (vs absent).

From $B$. siremps, the new species differs in having slightly longer body $(\mathrm{L}=0.42-0.44$ vs $0.30-0.39 \mathrm{~mm})$; longer total stylet (21-22 vs $15.5-17.5 \mu \mathrm{m}$, odontostyle 9.5-10.0 vs 7.5-8.5 $\mu \mathrm{m}$; odontophore 11.512.0 vs $8.0-9.0 \mu \mathrm{m})$; comparatively posterior vulva position ( $\mathrm{V}=55-58$ vs $47-53)$; lower c $(25-27$ vs 27-43) ratio; differently shaped tail (tail convex-conoid with acute terminus vs tail with rounded to hemispherical terminus); longer spicules (20 vs $12.5 \mu \mathrm{m})$ and presence ventromedian supplements (vs absent).

From $B$. nindei, the new species differs in having wider lip region ( $8.0-8.5 \mathrm{vs} 6.0-7.0 \mu \mathrm{m})$; posterior vulva position ( $\mathrm{V}=55-58$ vs 39-45); presence of longer anterior uterine sac (15-20 vs anterior uterine sac usually absent, rarely present, $4.5-6.0 \mu \mathrm{m}$ ); differently shaped tail (tail conoid with acute terminus vs bluntly rounded to conoid terminus) and presence of male (vs male absent).

From B. minutus, the new species differs in having wider lip region (8.0-8.5 vs 5.0-7.0 $\mu \mathrm{m})$; amphids simple, stirrup-shaped (vs duplex, stirrup-shape); posterior vulva position ( $\mathrm{V}=55-58$ vs $32-42$ ); differently shaped tail (tail conoid with acute terminus vs rounded to conoid terminus) and presence of male (vs absent).

The new species also comes close to B. discinus Siddiqi, 1995 and B. diminutus Siddiqi, 1995 but differs from the former in having robust body ( $\mathrm{a}=21-22$ vs 28$)$; absence of labial disc (vs labial disc present); odontophore with distinct basal flanges (vs odontophore with poorly developed basal flanges); posterior vulva position ( $\mathrm{V}=55-58$ vs 51$)$ and lower c (25-27 vs 35$)$ ratio.

From $B$. diminutus, the new species differs in having slightly longer and slender body $(\mathrm{L}=0.42-0.44$ vs $0.29-0.36 \mathrm{~mm}, \mathrm{a}=21-22$ vs $17-20)$; longer total stylet (21-22 vs $16.0-18.5 \mu \mathrm{m})$ and odontostyle (9.5-10 vs 7.5-8.5 $\mu \mathrm{m}$ ), odontophore with well developed basal flanges (vs poorly developed flanges); posterior vulva position ( $\mathrm{V}=55-58$ vs $37-42)$; presence of anterior uterine sac (vs absent) and differently shaped tail (conoid with acute terminus vs hemispherical to rounded).

In the presence of a conoid tail the new species comes close to B. caudatus Jairajpuri, 1966; B. lieberi Goseco et al., 1974 and B. westralis Siddiqi, 1970, but differs from B. caudatus in having odontophore with basal flanges (vs odontophore without flanges); posterior vulva position ( $\mathrm{V}=$ 55-58 vs 40-48); presence of anterior uterine sac (vs anterior uterine sac absent) and presence of male (vs male absent).

From $B$. lieberi, the new species differs in having shorter body $(\mathrm{L}=0.42-0.44$ vs $0.67-0.90 \mathrm{~mm})$; female genital system mono-opisthodelphic (vs mono-prodelphic) and smaller spicules (20 vs 24-28 $\mu \mathrm{m}$ ).

From $B$. westralis, the new species differs in having shorter body $(\mathrm{L}=0.42-0.44$ vs $0.55-0.75 \mathrm{~mm})$; female genital system mono-opisthodelphic (vs amphidelphic) and smaller spicules (20 vs 22$25 \mu \mathrm{m}$ ). 


\section{Basirotyleptus constrictus sp. nov. urn:lsid:zoobank.org:act:D3AB632D-0286-4577-9A83-78E61A57225E}

Figs 10-11, Table 8

\section{Diagnosis}

Basirotyleptus constrictus sp. nov. is characterized by having $0.38-0.49 \mathrm{~mm}$ long body; lip region caplike, offset by constriction; lips rounded, inner part elevated, forming a perioral disc; odontostyle 9.5$10 \mu \mathrm{m}$ long, odontophore 14-15 $\mu \mathrm{m}$ long, total stylet length $23.5-25.0 \mu \mathrm{m}$; pharynx slender with slightly muscular anterior part, expanding abruptly into a short pear-shaped basal bulb separated by constriction, occupying about $15-17 \%$ of total neck length; female genital system monodelphic-opisthodelphic; anterior genital branch absent or rarely a very small sac, $4.0-6.0 \mu \mathrm{m}$ or one-fourth to one-third midbody diameter long, tail short, with conoid to bluntly rounded terminus, 1.1-1.4 times anal body diameter long.

\section{Etymology}

The new species is named Basirotyleptus constrictus sp. nov. because of its pharyngeal bulb separated by constriction.

\section{Material examined}

\section{Holotype}

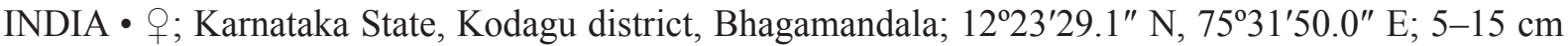
depth; 8 Nov. 2017; roots of shrubs and forest trees (unidentified); slide reference number AMU/ZD/ $\mathrm{NC} /$ Basirotyleptus constrictus/1.

\section{Paratypes}

INDIA $\bullet 8$ + ; same collection data as for holotype; slides reference number AMU/ZD/NC/Basirotyleptus constrictus/2-5.

\section{Type habitat and locality}

Soil samples collected from around the roots of shrubs and forest trees (unidentified) from Bhagamandala, Kodagu, Karnataka State.

\section{Description}

Female

Small sized nematodes, slightly curved ventrad or open C-shaped upon fixation, tapering gradually towards both extremities but more so towards anterior end. Cuticle with two distinct layers, $1.0-1.5 \mu \mathrm{m}$ thick at anterior region, 1.5-2.0 $\mu \mathrm{m}$ at midbody and 2.0-2.5 $\mu \mathrm{m}$ on tail. Outer cuticle thin, with fine transverse striations; inner layer thick, finely striated, loose, its outline irregular, with distinct radial refractive elements. Lateral chords occupying about $25-30 \%$ of midbody diameter. Lateral, dorsal and ventral body pores indistinct. Lip region cap-like, offset by constriction, 1.8-2.1 times as wide as high or about two-fifths to one-half of the body diameter at neck base. Lips rounded, amalgamated; inner part elevated, forming a perioral disc-like structure. Labial and cephalic papillae clear but not interfering with labial contour. Amphids stirrup-shaped, their aperture about one-half to three-fifths as wide as lip region diameter. Stoma a long, slender truncate cone, slightly sclerotized in the perioral region. Odontostyle slender, solid, needle-like, 1.2-1.3 times the lip region diameter long. Odontophore simple with basal flanges, about 1.4-1.6 times the odontostyle length. Guiding ring simple, refractive, at 1.0-1.2 times the lip region diameter from anterior end. Pharynx consisting of a slender and slightly muscular anterior part, expanding abruptly into a short, pear-shaped basal bulb, with a perceptible thickening at the posterior part of its inner lining, occupying about $15-17 \%$ of total neck length, two parts separated 

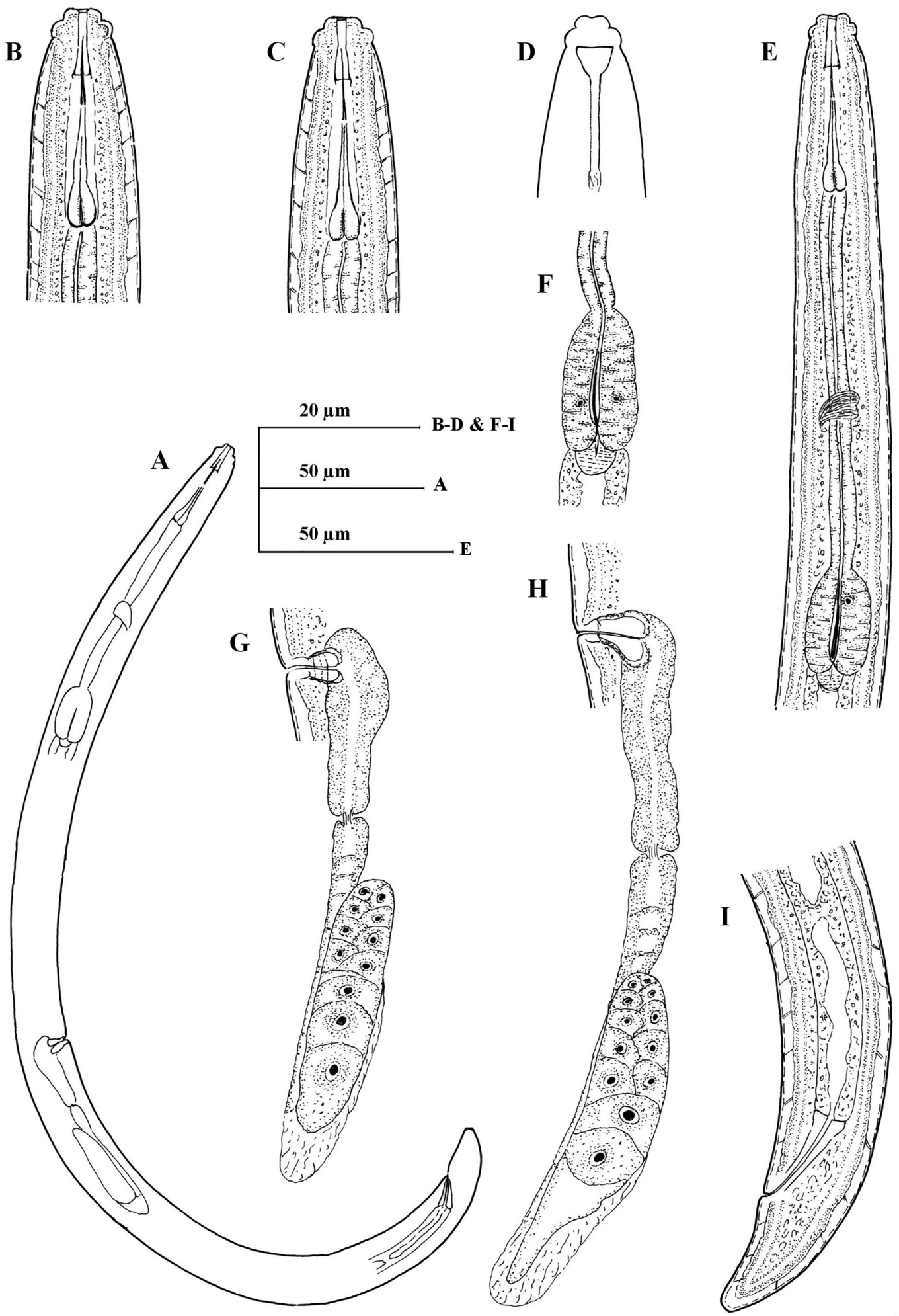

Fig. 10. Basirotyleptus constrictus sp. nov., \& (AMU/ZD/NC/Basirotyleptus constrictus/2-5). A. Paratype 3. B, H. Paratype 1. C-E, I. Paratype 5. F. Paratype 4. G. Paratype 2. A. Entire specimen. B-C. Anterior region. D. Anterior region showing amphid. E. Pharyngeal region. F. Pharyngeal bulb. G-H. Genital system. I. Posterior region. 

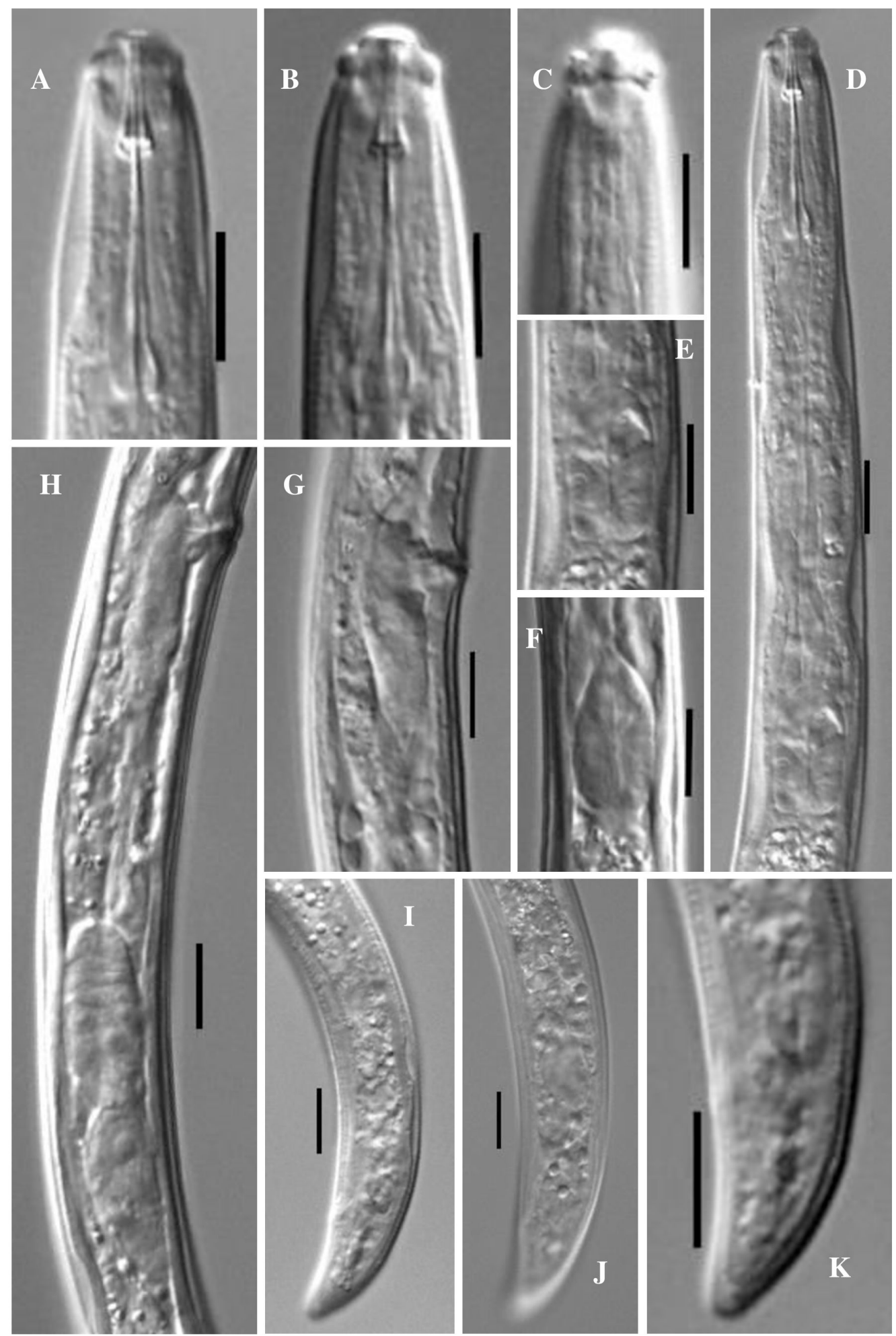

Fig. 11. Basirotyleptus constrictus sp. nov., q (LM photographs). A, C-F, H-I, K. Paratypes (AMU/ ZD/NC/Basirotyleptus constrictus/2-5). B, G, J. Holotype (AMU/ZD/NC/Basirotyleptus constrictus/1). A. Paratype 5. C. Paratype 7. D-E. Paratype 5. F. Paratype 2. H. Paratype 1. I, K. Paratype 3. A-B. Anterior region. C. Anterior region showing amphid. D. Pharyngeal region. E-F. Pharyngeal bulb. G-H. Genital system. I-J. Posterior region. K. Posterior end. Scale bars $=10 \mu \mathrm{m}$. 
Table 8. Measurements of Basirotyleptus constrictus sp. nov. All measurements are in $\mu \mathrm{m}$ and in the form: mean \pm s.d. (range).

\begin{tabular}{|c|c|c|}
\hline Characters & Holotype female & Paratype females \\
\hline $\mathrm{n}$ & & 8 \\
\hline $\mathrm{L}$ & 497 & $449.7 \pm 37.6(384-496)$ \\
\hline Body diameter at neck base & 17.5 & $17.1 \pm 0.92(15.5-18.5)$ \\
\hline Body diameter at mid body & 19.5 & $18.5 \pm 0.97(16.5-19.5)$ \\
\hline Body diameter at anus & 13.5 & $12.7 \pm 0.92(11.5-13.5)$ \\
\hline $\mathrm{a}$ & 25.4 & $23.7 \pm 1.2(22.5-26.6)$ \\
\hline $\mathrm{b}$ & 4.4 & $4.0 \pm 0.26(3.6-4.6)$ \\
\hline $\mathrm{c}$ & 29.9 & $26.8 \pm 1.8(24.5-30)$ \\
\hline$c^{\prime}$ & 1.2 & $1.2 \pm 0.09(1.1-1.4)$ \\
\hline $\mathrm{V}$ & 54.5 & $52.9 \pm 1.6(51.5-56.6)$ \\
\hline G1 & 0.78 & $1.0 \pm 0.28(0.77-1.3)$ \\
\hline G2 & 21.0 & $21.2 \pm 1.2(19.5-23.3)$ \\
\hline Lip region diameter & 8.5 & $8.2 \pm 0.41(8.0-8.5)$ \\
\hline Lip region height & 4.0 & $4.2 \pm 0.15(4.0-4.5)$ \\
\hline Amphidial aperture & 4.5 & $4.3 \pm 0.43(4.0-5.0)$ \\
\hline Odontostyle length & 9.5 & $9.8 \pm 0.23(9.0-10)$ \\
\hline Odontophore length & 14.5 & $14.2 \pm 0.36(14-15)$ \\
\hline Total stylet length & 24 & $24.3 \pm 0.39(23.5-25)$ \\
\hline Guiding ring from anterior end & 9.0 & $8.9 \pm 0.50(8.0-10)$ \\
\hline Nerve ring from anterior end & 65 & $63.3 \pm 2.0(60-65)$ \\
\hline Neck length & 111 & $108.4 \pm 3.0(103-112)$ \\
\hline Expanded part of pharynx & 17 & $17.6 \pm 0.46(16-19)$ \\
\hline Cardia length & 4.5 & $4.1 \pm 0.69(3.0-5.0)$ \\
\hline Anterior genital branch & 4.0 & $4.9 \pm 0.98(4.0-6.0)$ \\
\hline Posterior genital branch & 104 & $97.6 \pm 9.8(78-111)$ \\
\hline Vaginal length & 9.0 & $8.9 \pm 0.57(8.5-10)$ \\
\hline Vulva from anterior end & 271 & $239.7 \pm 22.5(201-268)$ \\
\hline Prerectum length & 30 & $35.7 \pm 4.5(30-43)$ \\
\hline Rectum length & 16.5 & $14.9 \pm 1.2(12.5-16.5)$ \\
\hline Tail length & 16.5 & $16.4 \pm 1.3(15.0-18.0)$ \\
\hline
\end{tabular}


by constriction. Nerve ring at 56-60\% of neck length from anterior end. Cardia short, rounded to conoid, about one-fifth to one-third of the corresponding body diameter long.

Genital system monodelphic-opisthodelphic. Ovary reflexed, measuring $51-71 \mu \mathrm{m}$; oocytes arranged in single row except near tip. Oviduct joining the ovary subterminally, measuring 29-54 $\mu \mathrm{m}$, consisting of a slender distal portion and a poorly developed pars dilatata. Oviduct-uterus junction marked by weak sphincter. Uterus short and tubular, measuring 21-27 $\mu \mathrm{m}$. Anterior genital branch absent or sometimes reduced to small sac $(n=3), 4.0-6.0 \mu \mathrm{m}$ or about one-fifth to one-third midbody diameter long. Sperm cell absent. Vagina cylindrical, extending inwards, $8.5-10.0 \mu \mathrm{m}$ or about two-fifths to one-half $(43-53 \%)$ of midbody diameter; pars proximalis vaginae 5.0-7.0 $\times 3.0-4.0 \mu \mathrm{m}$, encircled by circular muscles; pars distalis vaginae long, 3.0-4.0 $\mu \mathrm{m}$ with slightly curved walls; pars refringens absent. Vulva apparently a transverse slit. Prerectum 2.2-3.7 and rectum 0.9-1.3 times anal body diameter long. Tail short, conoid with bluntly rounded terminus, 1.1-1.4 times anal body diameter long, with a pair of caudal pores on each side.

\section{Male \\ Not found.}

\section{Remarks}

In the presence of a distinct labial disc, the new species comes close to B. discinus Siddiqi, 1995; B. ethiopicus Siddiqi, 1970 and B. nemoralis Siddiqi, 1970 but differs from B. discinus in having longer odontophore (14-15 vs 9.5-10 $\mu \mathrm{m}$ ), with distinct basal flanges (vs odontophore with poorly developed basal flanges); longer total stylet length $(23.5-25$ vs $18.5-19.5 \mu \mathrm{m})$; pharyngeal bulb separated by constriction (vs without constriction); anterior genital branch either absent or rarely present but very short (about $0.2-0.3$ vs one anal body diameter long), lower c (24-30 vs 35) ratio and absence of male (vs present).

From B. ethiopicus, the new species differs in having its odontophore with distinct basal flanges (vs odontophore without flanges); pharyngeal bulb separated by constriction (vs without constriction); posterior vulva position ( $\mathrm{V}=51-56 \mathrm{vs} 38-48$ ) and in the size and shape of tail (tail conoid vs comparatively short, rounded to hemispheroid, $\mathrm{c}=24-30$ vs $46-77, \mathrm{c}^{\prime}=1.1-1.4$ vs $0.50-0.80$ ).

From B. nemoralis, the new species differs in having odontophore with distinct basal flanges (vs odontophore without flanges), pharyngeal bulb separated by constriction (vs without constriction); posterior vulva position $(\mathrm{V}=51-56$ vs $43-50)$ and longer tail $(15-18$ vs $11.0 \mu \mathrm{m}, \mathrm{c}=24-30$ vs $45-58$, $\mathrm{c}^{\prime}=1.1-1.4$ vs 1.0$)$.

\section{Basirotyleptus goaensis sp. nov. urn:1sid:zoobank.org:act:E0A280BC-CE80-43F7-8637-BDE34EC5017F}

Figs 12-13, Table 9

\section{Diagnosis}

Basirotyleptus goaensis sp. nov. is characterized by having $0.73-0.87 \mathrm{~mm}$ long body; lip region cap-like, offset by deep constriction; lips rounded, slightly angular, separated, inner part elevated; odontostyle 13.0-14.5 $\mu \mathrm{m}$ long, odontophore 15.0-17.5 $\mu \mathrm{m}$ long, total stylet length $28.5-31.0 \mu \mathrm{m}$; pharynx with a slender anterior part, expanding gradually into a short pyriform basal bulb, occupying about $16-18 \%$ of total neck length; female genital system monodelphic-opisthodelphic; anterior genital branch reduced to a simple sac, $24.5-46.0 \mu \mathrm{m}$ or 1.0-1.6 times midbody diameter long, tail short, rounded to conoid, $0.7-0.8$ times anal body diameter long. 


\section{Etymology}

The new species is named Basirotyleptus goaensis sp. nov. because of its type locality Goa.

\section{Material examined}

\section{Holotype}

INDIA • O; Goa State, South Goa district, Madgaon; $15^{\circ} 09^{\prime} 03.5^{\prime \prime} \mathrm{N}, 74^{\circ} 01^{\prime} 05.5^{\prime \prime}$ E; 5-15 cm depth; 19 April. 2016; roots of shrubs (unidentified); slide reference number AMU/ZD/NC/Basirotyleptus goaensis/1.

\section{Paratypes}

INDIA $\bullet 7$ 우; same collection data as for holotype; slides reference number AMU/ZD/NC/Basirotyleptus goaensis/2-6.

\section{Type habitat and locality}

Soil samples collected from around the roots of shrubs and forest trees (unidentified) from Madgaon, Goa State.

\section{Description}

\section{Female}

Small sized nematodes, slightly curved ventrad or open C-shaped upon fixation; body cylindrical, tapering gradually towards both extremities but more so towards the anterior end. Cuticle with two distinct layers, $1.0-1.5 \mu \mathrm{m}$ thick at anterior region, $2.0-2.5 \mu \mathrm{m}$ at midbody and $2.5-3.0 \mu \mathrm{m}$ on tail. Outer cuticle thin, finely striated, with distinct rows of punctations; inner layer thick, finely striated, loose, its outline irregular, with distinct radial refractive elements but more so towards posterior region. Lateral chords occupying about $24-32 \%$ of midbody diameter. Lateral body pores distinct; $1-3$ in neck region; 2-3 from pharyngeal base to vulva; $3-7$ in post-vulval region. Dorsal and ventral body pores indistinct. Lip region cap-like, offset by deep constriction, 2.0-2.2 times as wide as high or about onethird of the body diameter at neck base. Lips rounded, slightly angular, separated, inner part elevated. Labial and cephalic papillae distinct and slightly raised above the labial contour. Amphids large, duplex, cup-shaped, their aperture about three-fifths to two-thirds as wide as lip region diameter. Stoma a long, slender truncate cone, slightly sclerotized in the perioral region. Odontostyle slender, solid, needlelike, 1.5-1.6 times the lip region diameter long. Odontophore simple, sclerotized, about 1.1-1.2 times the odontostyle length. Guiding ring simple, refractive, at 1.2-1.3 times the lip region diameter from anterior end. Pharynx consisting of a slender anterior part, expanding gradually into a short pyriform bulb, with a perceptible thickening at the posterior part of its inner lining, occupying about $16-18 \%$ of total neck length. Nerve ring at 56-60\% of neck length from anterior end. Cardia rounded to conoid, about one-seventh to one-fifth of the corresponding body diameter long.

Genital system monodelphic-opisthodelphic. Ovary reflexed, measuring 73-167 $\mu$ m; oocytes arranged in single row except near tip. Oviduct joining the ovary subterminally, measuring $73-132 \mu \mathrm{m}$, consisting of a slender distal portion and a well-developed pars dilatata. Oviduct-uterus junction marked by distinct sphincter. Uterus short and wide tubular, measuring 36-52 $\mu \mathrm{m}$. Anterior genital branch reduced to a simple sac, about 1.0-1.6 times midbody diameter long. Sperm cells present throughout the genital tract. Vagina cylindrical, extending inwards, $12-14 \mu \mathrm{m}$ or about one-half (46-51\%) of midbody diameter; pars proximalis vaginae $8.5-9.5 \times 5.5-7.5 \mu \mathrm{m}$, encircled by circular muscles; pars distalis vaginae long, 4.0-5.0 $\mu \mathrm{m}$ with slightly curved walls; pars refringens absent. Vulva apparently a transverse slit. Prerectum 3.0-4.1 and rectum 0.8-1.1 times anal body diameter long. Tail short, rounded to conoid, $0.7-0.8$ times anal body diameter long, with a pair of caudal pores on each side. 

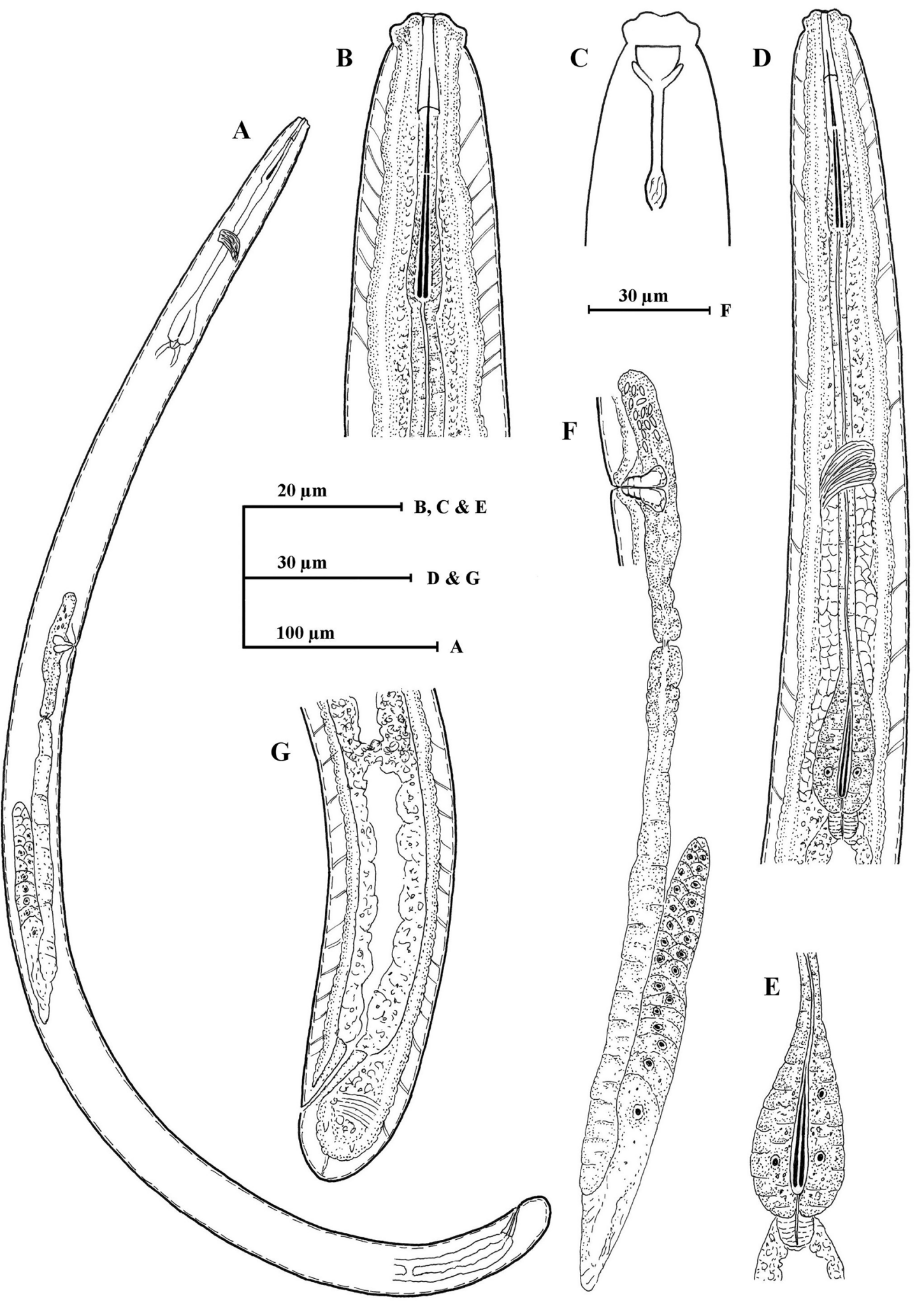

Fig. 12. Basirotyleptus goaensis sp. nov., ๆ. A-E, G. Paratypes (AMU/ZD/NC/Basirotyleptus goaensis/2-6). A. Paratype 7. B, D, G. Paratype 4. C. Paratype 2. E. Paratype 1. F. Holotype (AMU/ $\mathrm{ZD} / \mathrm{NC} /$ Basirotyleptus goaensis/1). A. Entire specimen. B. Anterior region. C. Anterior region showing amphid. D. Pharyngeal region. E. Pharyngeal bulb. F. Genital system. G. Posterior region. 

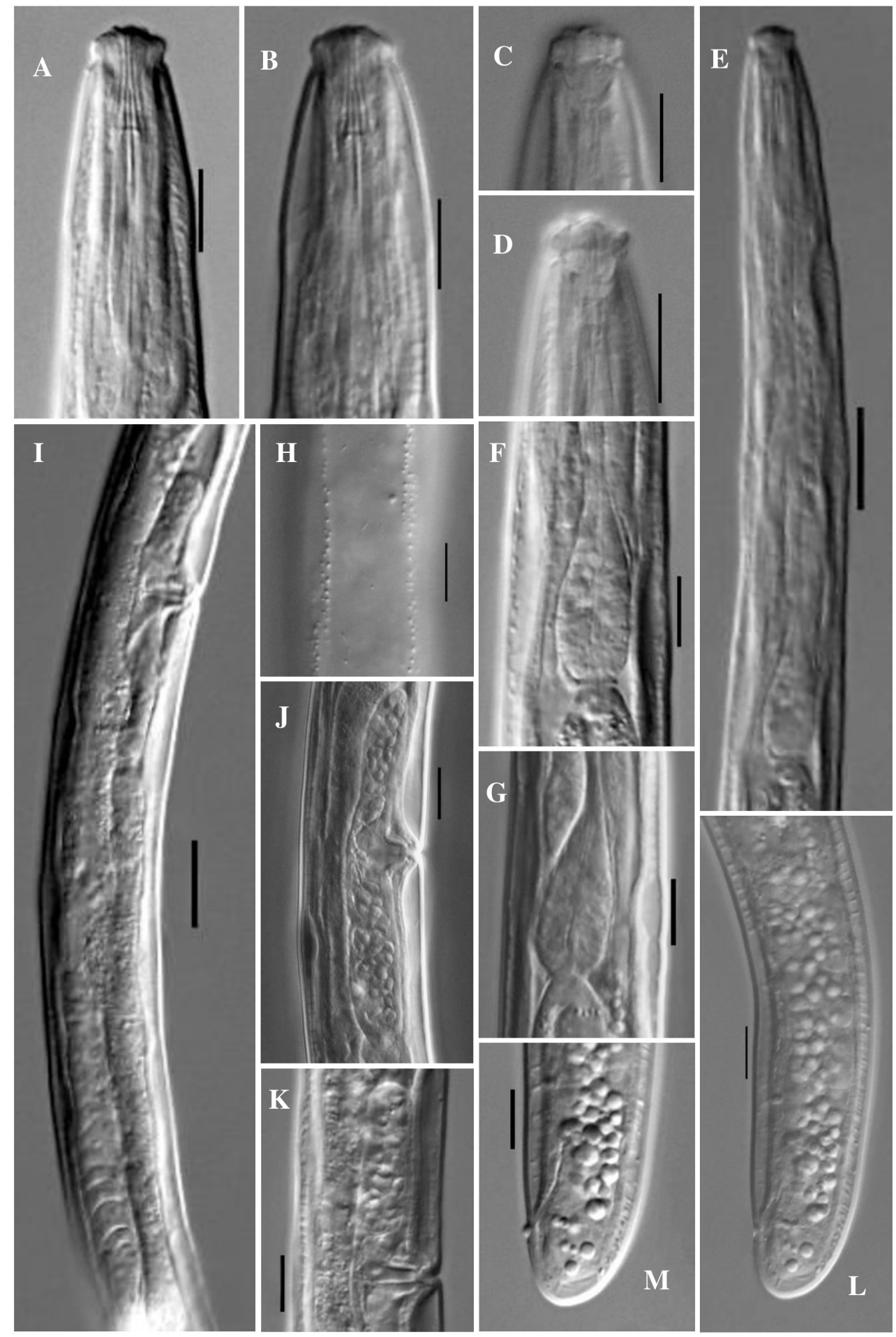

Fig. 13. Basirotyleptus goaensis sp. nov., $q$ (LM photographs). A-B, D-M. Paratypes (AMU/ZD/NC/ Basirotyleptus goaensis/2-6). A, D-F, H, K. Paratype 1. B, G, J. Paratype 2. C. Holotype (AMU/ ZD/NC/Basirotyleptus goaensis/1). I. Paratype 4. L. Paratype 5. M. Paratype 3. A-B. Anterior region. C-D. Anterior region showing amphid. E. Pharyngeal region. F-G. Pharyngeal bulb. H. Cuticle showing punctations. I-K. Genital system. L. Posterior region. M. Posterior end. Scale bars: A-D, F-H, J-K, $\mathrm{M}=10 \mu \mathrm{m} ; \mathrm{E}, \mathrm{I}=20 \mu \mathrm{m}$. 
Table 9. Measurements of Basirotyleptus goaensis sp. nov. All measurements are in $\mu \mathrm{m}$ and in the form: mean \pm s.d. (range)

\begin{tabular}{|c|c|c|}
\hline Characters & Holotype female & Paratype females \\
\hline $\mathrm{n}$ & & 7 \\
\hline $\mathrm{L}$ & 849 & $813.6 \pm 48.7(730-873)$ \\
\hline Body diameter at neck base & 24.5 & $23.8 \pm 1.2(22.0-25.0)$ \\
\hline Body diameter at mid body & 26.5 & $27.1 \pm 1.4(24.5-28.5)$ \\
\hline Body diameter at anus & 18 & $18.1 \pm 1.3(16.0-20.5)$ \\
\hline $\mathrm{a}$ & 32.1 & $29.4 \pm 1.2(28.4-32.1)$ \\
\hline $\mathrm{b}$ & 6.1 & $5.7 \pm 0.33(5.3-6.2)$ \\
\hline $\mathrm{c}$ & 54.2 & $55.3 \pm 3.1(51.6-62.0)$ \\
\hline$c^{\prime}$ & 0.84 & $0.79 \pm 0.05(0.72-0.88)$ \\
\hline V & 38.9 & $36.6 \pm 0.93(36.0-38.2)$ \\
\hline G1 & 4.1 & $3.6 \pm 0.34(3.1-4.0)$ \\
\hline G2 & 20.0 & $23.0 \pm 2.3(19.5-25.8)$ \\
\hline Lip region diameter & 9.0 & $9.0 \pm 0.39(8.5-10)$ \\
\hline Lip region height & 4.0 & $4.1 \pm 0.24(4.0-4.5)$ \\
\hline Amphidial aperture & 6.0 & $5.6 \pm 0.35(5.0-6.0)$ \\
\hline Odontostyle length & 14 & $13.7 \pm 0.38(13.0-14.5)$ \\
\hline Odontophore length & 16.5 & $16.1 \pm 0.73(15.0-17.5)$ \\
\hline Total stylet length & 30.5 & $29.9 \pm 0.93(28.5-31.0)$ \\
\hline Guiding ring from anterior end & 12 & $11.8 \pm 0.53(10.5-12.5)$ \\
\hline Nerve ring from anterior end & 79 & $79.3 \pm 2.1(75-83)$ \\
\hline Neck length & 137 & $137.9 \pm 3.4(132-144)$ \\
\hline Expanded part of pharynx & 24.5 & $23.8 \pm 1.1(22.5-26.0)$ \\
\hline Cardia length & 5.0 & $4.7 \pm 0.39(4.0-5.0)$ \\
\hline Anterior genital branch & 35 & $31.6 \pm 6.4(24.5-46.0)$ \\
\hline Posterior genital branch & 170 & $191.2 \pm 22.4(152-225)$ \\
\hline Vaginal length & 13.5 & $13.4 \pm 0.64(13.0-14.5)$ \\
\hline Vulva from anterior end & 330 & $304.1 \pm 17.5(279-330)$ \\
\hline Prerectum length & 72 & $67.3 \pm 6.8(52-73)$ \\
\hline Rectum length & 21 & $18.0 \pm 2.0(14.5-21.5)$ \\
\hline Tail length & 15.5 & $14.4 \pm 1.2(12.0-15.5)$ \\
\hline
\end{tabular}




\section{Male \\ Not found. \\ Remarks}

In the presence of a comparatively long body, simple odontophore and presence of long anterior uterine sac, the new species comes close to B. upicus Ahmad \& Jairajpuri 1979; B. rotundicaudatus (Khan, 1987); B. basiri Jairajpuri, 1964 and B. pini Siddiqi \& Khan, 1965 but differs from B. upicus in the presence of distinct punctations on cuticle (vs punctations absent); lip region with differently shaped amphid (duplex, cup-shaped vs simple, cup-shaped); guiding ring slightly more posterior (1.2-1.3 times vs one lip region diameter from anterior end); longer total stylet and odontophore (stylet 28.5-31.0 vs 25-27 $\mu \mathrm{m}$, odontophore $15.0-17.5$ vs $11-13 \mu \mathrm{m})$; longer pharyngeal bulb (22.5-26.0 vs $20-22 \mu \mathrm{m}$ or $16-18$ vs $15-16 \%$ of total neck length); slightly anterior vulva position $(\mathrm{V}=36-39$ vs $39-42)$; longer prerectum ( $52-73$ vs $45-50 \mu \mathrm{m}$ or 3.0-4.1 vs $2.5-2.7$ times anal body diameter); shorter tail ( $12-15 \mathrm{vs}$ $17-20 \mu \mathrm{m}, \mathrm{c}=51-62$ vs $41-48)$ and absence of male (vs present).

From B. rotundicaudatus, the new species differs in having differently shaped amphids (duplex, cupshaped vs simple, cup-shaped), absence of hypodermal glands (vs present); pharyngeal expansion gradual (vs abrupt) and longer pharyngeal bulb (22.5-26.0 vs $19 \mu \mathrm{m})$; absence of flanges at base of odontophore (vs small flanges present); shorter anterior uterine sac (24.5-46.0 vs $65 \mu \mathrm{m})$; higher c (51-62 vs 42-47) ratio and absence of male (vs male present).

From $B$. basiri, the new species differs in having longer body $(\mathrm{L}=0.73-0.87$ vs $0.45-0.71 \mathrm{~mm})$, presence of punctations on cuticle (vs punctations absent); lip region offset by deep constriction (vs slight constriction); differently shaped amphid (duplex, cup-shaped vs simple, stirrup-shaped); wider lip region (8.5-10.0 vs 8.0-8.5 $\mu \mathrm{m}$ ); longer total stylet length and odontophore (28.5-31.0 vs 22.0$24.5 \mu \mathrm{m}, 15.0-17.5$ vs $11.5-13 \mu \mathrm{m})$; longer pharyngeal bulb (22.5-26.5 vs $16.5-20.5 \mu \mathrm{m})$ and absence of male (vs present).

From B. pini, the new species differs in having a longer body $(\mathrm{L}=0.73-0.87$ vs $0.49-0.62 \mathrm{~mm})$, presence of punctations on cuticle (vs punctations absent); longer odontostyle $(13.0-14.5$ vs 11.0-12.5 $\mu \mathrm{m})$; longer pharyngeal bulb (22.5-26.5 vs 17-20.5 $\mu \mathrm{m})$; longer anterior uterine sac $(24.5-46 \mathrm{vs} 8.0-18 \mu \mathrm{m}$ or 1.0-1.6 times vs less than one midbody diameter long).

Basirotyleptus neocaudatus sp. nov. urn:lsid:zoobank.org:act:E9DD76EF-C8B7-450B-B019-F77513AE8C42

Figs $14-15$, Table 10

\section{Diagnosis}

Basirotyleptus neocaudatus sp. nov. is characterized by having $0.31-0.44 \mathrm{~mm}$ long body; lip region cap-like, offset by constriction; lips rounded, inner part slightly elevated; odontostyle 7.5-9.5 $\mu \mathrm{m}$ long, odontophore 10-13 $\mu \mathrm{m}$ long, total stylet length 18-22 $\mu \mathrm{m}$; pharynx a slender anterior part, expanding abruptly into a short pyriform basal bulb, occupying about $14-19 \%$ of total neck length; female genital system monodelphic-opisthodelphic; anterior genital branch absent or rarely a very small sac, 3.0 $5.0 \mu \mathrm{m}$ or less one-third midbody diameter long, tail with convex-conoid to digitate acute terminus, 1.1-1.7 times anal body diameter long; male with $20.5 \mu \mathrm{m}$ long spicules, $5.5 \mu \mathrm{m}$ long lateral guiding pieces and two ventromedian supplements.

\section{Etymology}

The new species is named Basirotyleptus neocaudatus sp. nov. because of its tail close to B. caudatus. 


\section{Material examined}

Holotype

INDIA • + ; Kerala State, Kasaragad district, Ranipuram National Park; $12.4^{\circ} 26^{\prime} 18.3^{\prime \prime}$ N, $75.3^{\circ} 58^{\prime} 94.4^{\prime \prime}$ E; 5-15 cm depth; 7 Nov. 2016; soil samples collected from around the roots of grasses (unidentified); slide reference number AMU/ZD/NC/Basirotyleptus neocaudatus/1.

\section{Paratypes}

INDIA -5 우, 1 ; same collection data as for holotype; slides reference number AMU/ZD/NC/ Basirotyleptus neocaudatus/2-4.

\section{Additional material}

INDIA - Kerala State • 14 q $q$; Palakkad district, Mukkali Forest; $11^{\circ} 03^{\prime} 40.7^{\prime \prime}$ N, 76 32.7'23.8" E; 5-15 cm depth; 26 Oct. 2017; soil samples collected from around the roots of grasses (unidentified); slides reference number AMU/ZD/NC/Basirotyleptus neocaudatus/5-9 • 16 우; Idukki district, Muttam; $9^{\circ} 49^{\prime} 22.8^{\prime \prime} \mathrm{N}, 76^{\circ} 43^{\prime} 40.8^{\prime \prime} \mathrm{E}$; 5-15 cm depth; 30 Oct. 2017; soil samples collected from around the roots of grasses (unidentified); slides reference number AMU/ZD/NC/Basirotyleptus neocaudatus/10-15.

\section{Type habitat and locality}

Soil samples collected from around the roots of grasses (unidentified) from Ranipuram National Park, Kasaragad district, Kerala State.

\section{Other habitat and localities}

Soil samples collected from around the roots of grasses (unidentified) from Mukkali forest, Palakkad district and from Muttam, Idukki district, Kerala State.

\section{Description}

\section{Female}

Small sized nematodes, slightly curved ventrad or open C-shaped upon fixation; body cylindrical, tapering gradually towards both extremities but more so towards the anterior end. Cuticle with two distinct layers, $1.0-1.5 \mu \mathrm{m}$ thick at anterior region, $1.5-2.0 \mu \mathrm{m}$ at midbody and $2.0-2.5 \mu \mathrm{m}$ on tail. Outer cuticle thin, with fine transverse striations; inner layer thick, its outline loose, irregular, distinctly striated, with distinct radial refractive elements. Lateral chords occupying about $25-35 \%$ of midbody diameter. Lateral body pores distinct; one at odontostyle-odontophore region; $1-2$ in neck region; 2-3 at neck to vulval region and 3-9 at post-vulval region. Dorsal and ventral body pores indistinct. Lip region cap-like, offset by constriction, 2.0-2.3 times as wide as high or about two-fifths of the body diameter at neck base. Lips slightly angular, separated, inner part slightly elevated. Labial and cephalic papillae distinct but not interfering with labial contour. Amphids stirrup-shaped, their aperture about one-half to three-fifths as wide as lip region diameter. Stoma a long, slender truncate cone, slightly sclerotized in the perioral region. Odontostyle slender, solid, needle-like, 1.0-1.4 times the lip region diameter long. Odontophore simple, sclerotized, slightly swollen at base surrounded by pharyngeal tissue, 1.2-1.5 times the odontostyle length. Guiding ring simple, refractive, at 1.1-1.4 times the lip region diameter from anterior end. Pharynx consisting of a slender anterior part, expanding abruptly into a short pearshaped basal bulb, with a perceptible thickening at the posterior part of its inner lining, occupying about $14-19 \%$ of total neck length. Nerve ring at $49-64 \%$ of neck length from anterior end. Cardia rounded to conoid, about one-sixth to one-third of the corresponding body diameter long.

Genital system monodelphic-opisthodelphic. Ovary reflexed, measuring 33-69 $\mu \mathrm{m}$; oocytes arranged in single row except near tip. Oviduct joining the ovary subterminally, measuring $27-52 \mu \mathrm{m}$, consisting of a slender distal portion and a well-developed pars dilatata. Oviduct-uterus junction marked by weak 


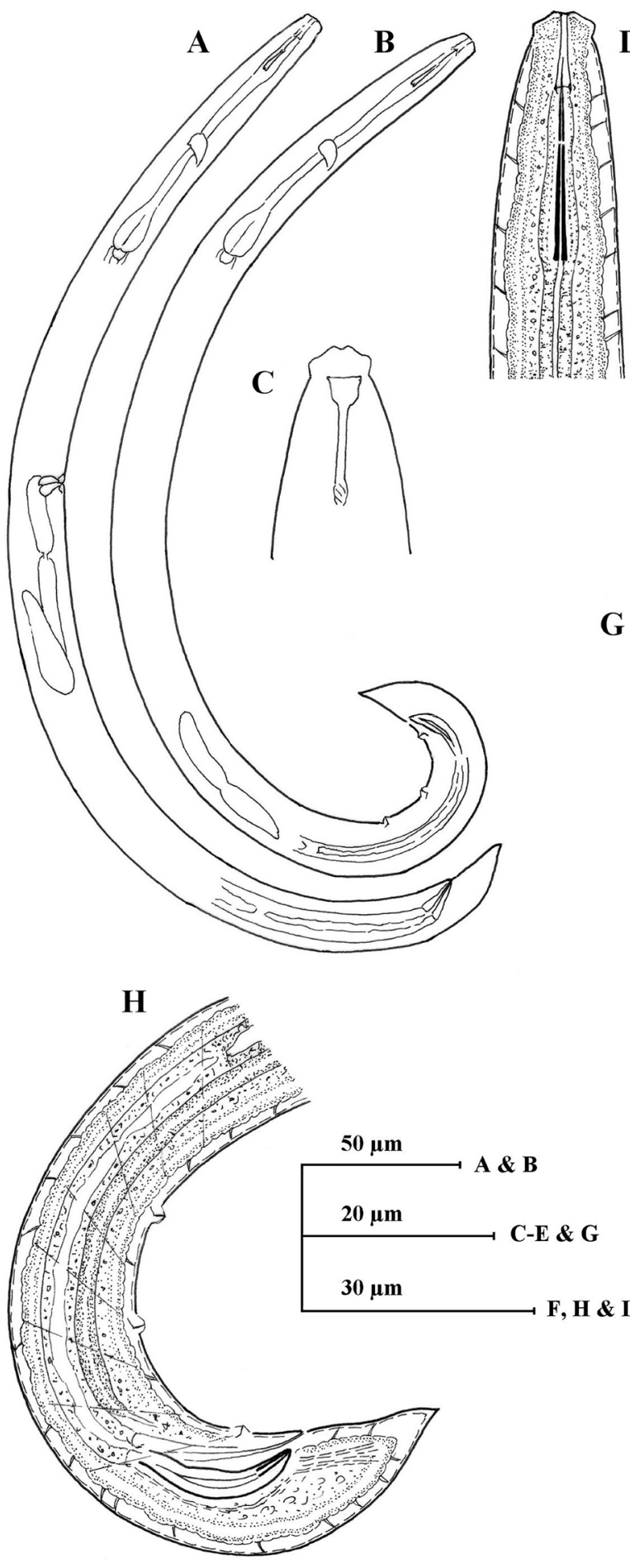

D
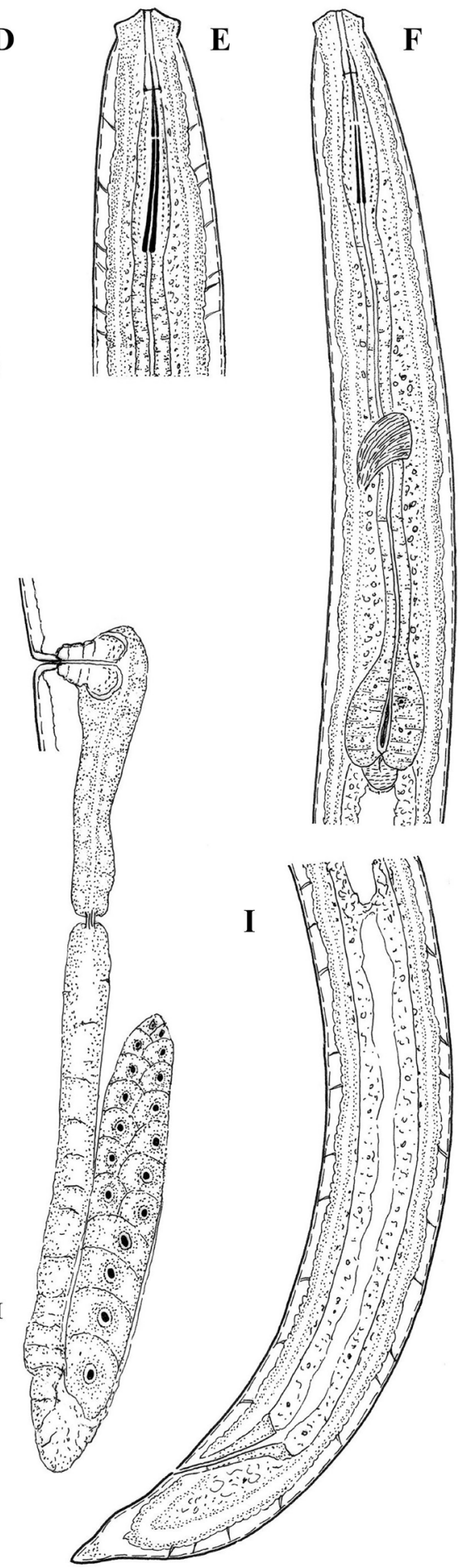

Fig. 14. Basirotyleptus neocaudatus sp. nov. A, C, E-F, I. Holotype, $q$ (AMU/ZD/NC/Basirotyleptus neocaudatus/1). B, H. Paratype, ô (AMU/ZD/NC/Basirotyleptus neocaudatus/4). D. Specimen 10, (AMU/ZD/NC/Basirotyleptus neocaudatus/6). G. Paratype 1, ㅇ (AMU/ZD/NC/Basirotyleptus neocaudatus/2). A. Entire female. B. Entire male. C. Female, anterior region showing amphid. D-E. Female, anterior region. F. Female, pharyngeal region. G. Female, genital system. H. Male, posterior region. I. Female, posterior region. 


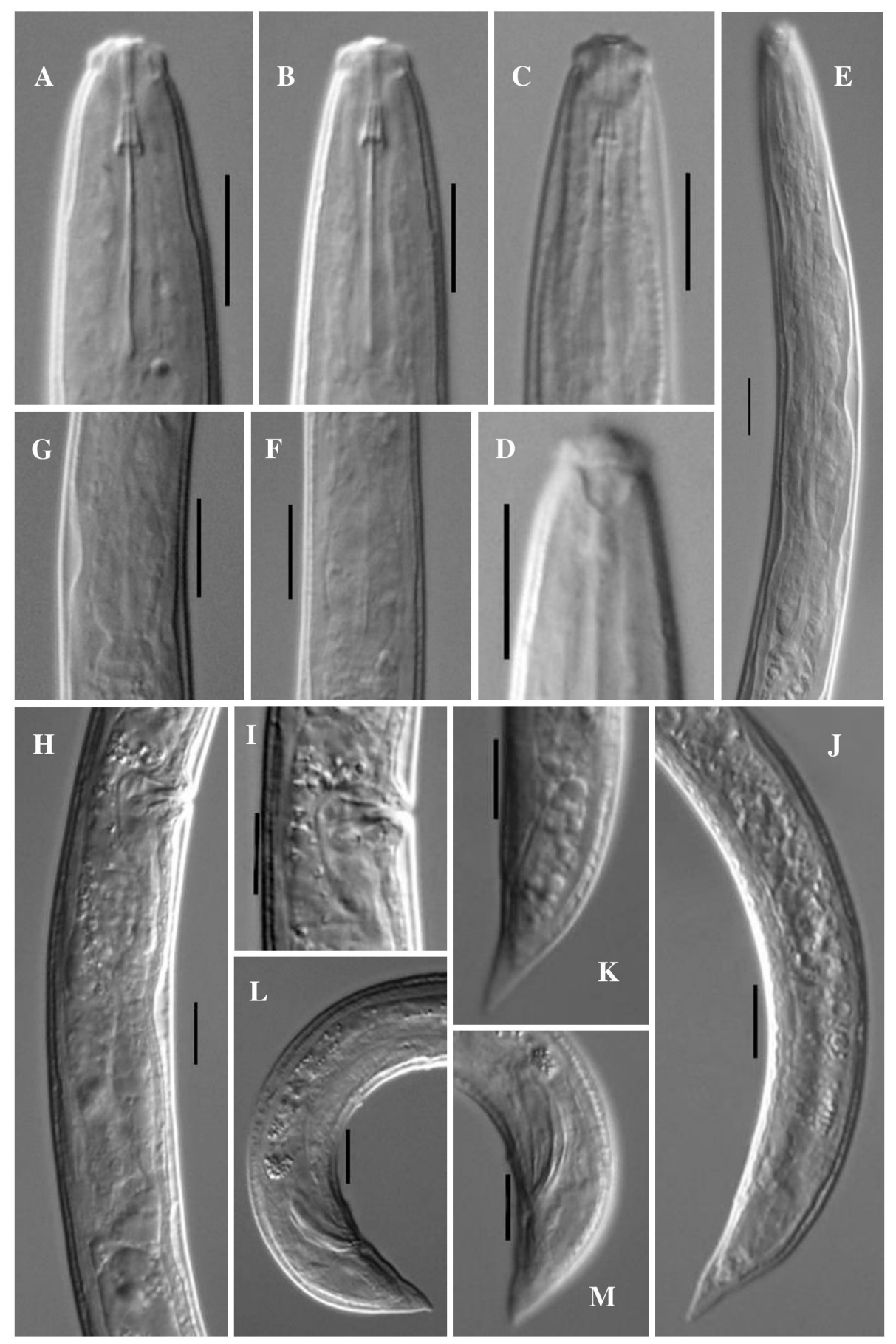

Fig. 15. Basirotyleptus neocaudatus sp. nov. (LM photographs). A, C-D, J-M. Paratypes (AMU/ $\mathrm{ZD} / \mathrm{NC} /$ Basirotyleptus neocaudatus/2-4). A, D. Paratype 6, 9 . B. Specimen 14, q (AMU/ZD/NC/ Basirotyleptus neocaudatus/9). C. Paratype 4, 9 . E. Specimen 21, ㅇ (AMU/ZD/NC/Basirotyleptus neocaudatus/11). F. Specimen 24, क (AMU/ZD/NC/Basirotyleptus neocaudatus/12). G. Specimen 25,

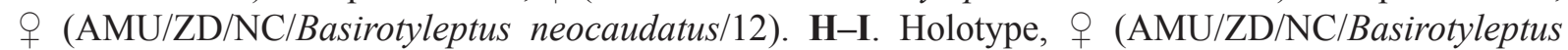
neocaudatus/1). J. Paratype 2, $\odot$. K. Paratype 1, + . L-M. Paratype, ô. A-C. Female, anterior region. D. Female, anterior region showing amphid. E. Female, pharyngeal region. F-G. Female, pharyngeal bulb. H. Female, genital system. I. Vulval region. J. Female, posterior region. K. Female, posterior end. L. Male, posterior region. M. Male, posterior end. Scale bars $=10 \mu \mathrm{m}$. 
Table 10. Measurements of Basirotyleptus neocaudatus sp. nov. All measurements are in $\mu \mathrm{m}$ and in the form: mean \pm s.d. (range).

\begin{tabular}{|c|c|c|c|c|c|}
\hline Localities & & Type population & & Palakkad population & Idukki population \\
\hline Characters & $\begin{array}{l}\text { Holotype } \\
\text { female }\end{array}$ & $\begin{array}{l}\text { Paratypes } \\
\text { females }\end{array}$ & $\begin{array}{l}\text { Paratype } \\
\text { male }\end{array}$ & females & males \\
\hline $\mathrm{n}$ & & 5 & 1 & 14 & 16 \\
\hline $\mathrm{L}$ & 417 & $397.6 \pm 31.3(343-441)$ & 418 & $349.3 \pm 24.6(312-402)$ & $367.8 \pm 22.6(343-434)$ \\
\hline Body diameter at neck base & 18.0 & $16.9 \pm 1.0(15.5-18.5)$ & 17.5 & $16.6 \pm 0.73(15.5-17.5)$ & $15.8 \pm 0.78(15-18)$ \\
\hline Body diameter at mid body & 19.5 & $18.2 \pm 0.99(16-20)$ & 19.5 & $18.1 \pm 0.87(16.5-19.5)$ & $17.3 \pm 0.94(15.5-18.5)$ \\
\hline Body diameter at anus & 12.5 & $11.9 \pm 0.73(10.5-12.5)$ & 16.5 & $11.1 \pm 0.70(10-13)$ & $10.6 \pm 0.90(10-13)$ \\
\hline $\mathrm{a}$ & 20.8 & $21.3 \pm 1.4(19.4-23.9)$ & 21.3 & $19.2 \pm 0.81(17.7-21.0)$ & $21.2 \pm 1.3(18.9-23.3)$ \\
\hline $\mathrm{b}$ & 4.0 & $3.8 \pm 0.15(3.8-4.1)$ & 3.9 & $3.9 \pm 0.33(3.4-4.6)$ & $3.9 \pm 0.41(3.5-5.2)$ \\
\hline c & 24.5 & $23.1 \pm 1.7(20.5-25.5)$ & 23.7 & $25.2 \pm 2.4(21.6-30.8)$ & $23.0 \pm 2.7(18.0-26.5)$ \\
\hline$c^{\prime}$ & 1.3 & $1.4 \pm 0.07(1.3-1.5)$ & 1.0 & $1.2 \pm 0.10(1.1-1.5)$ & $1.5 \pm 0.15(1.2-1.7)$ \\
\hline $\mathrm{V}$ & 43.7 & $43.2 \pm 0.63(42.8-44.5)$ & - & $44.8 \pm 1.6(42.7-48.3)$ & $44.6 \pm 1.7(41.4-48.0)$ \\
\hline G1 & 0.93 & $1.1 \pm 0.03(1.1-1.2)$ & - & $1.1 \pm 0.20(0.8-1.5)$ & $1.0 \pm 0.19(0.74-1.4)$ \\
\hline G2 & 19.9 & $19.6 \pm 3.4(16.0-25.2)$ & - & $20.6 \pm 2.1(16.9-24.6)$ & $20.0 \pm 1.3(18.8-23.4)$ \\
\hline Lip region diameter & 7.0 & $6.7 \pm 0.2(6.5-7.0)$ & 7.0 & $6.8 \pm 0.12(6.5-7.0)$ & $6.8 \pm 0.12(6.5-7.0)$ \\
\hline Lip region height & 3.5 & $3.0 \pm 0.2(3.0-3.5)$ & 3.5 & $3.2 \pm 0.20(3.0-3.5)$ & $3.2 \pm 0.23(3.0-3.5)$ \\
\hline Amphidial aperture & 3.5 & $3.4 \pm 0.19(3.0-3.5)$ & 3.5 & $3.6 \pm 0.30(3.0-4.0)$ & $3.7 \pm 0.23(3.5-4.0)$ \\
\hline Odontostyle length & 8.0 & $8.4 \pm 0.48(8.0-9.0)$ & 9.5 & $8.4 \pm 0.55(7.5-9.5)$ & $8.0 \pm 0.34(7.5-9.0)$ \\
\hline Odontophore length & 11 & $11.2 \pm 0.75(10-12)$ & 11.5 & $11.2 \pm 0.58(10-13)$ & $11.3 \pm 0.82(10.0-12.5)$ \\
\hline Total stylet length & 19 & $19.6 \pm 1.0(18-20.5)$ & 21 & $19.7 \pm 1.1(19-22)$ & $19.2 \pm 1.0(18-21)$ \\
\hline Guiding ring from anterior end & 8.5 & $8.1 \pm 0.39(8.0-9.0)$ & 8.5 & $8.6 \pm 0.30(8.0-9.0)$ & $8.1 \pm 0.49(7.0-9.0)$ \\
\hline Nerve ring from anterior end & 56 & $53.5 \pm 4.6(47-57)$ & 60 & $49.6 \pm 2.6(44-54)$ & $53.5 \pm 3.7(45-59)$ \\
\hline Neck length & 101 & $98.4 \pm 6.2(90-105)$ & 105 & $88.3 \pm 5.2(78-97)$ & $94.5 \pm 6.8(84-103)$ \\
\hline Expanded part of pharynx & 15 & $16.4 \pm 1.8(15-20)$ & 15.5 & $16.7 \pm 1.1(14.0-18.5)$ & $15.6 \pm 0.83(15-17)$ \\
\hline Cardia length & 4.0 & $3.9 \pm 0.61(3.0-5.0)$ & 4.0 & $4.2 \pm 0.58(3.0-5.0)$ & $3.8 \pm 0.44(3.0-5.0)$ \\
\hline Anterior genital branch & 4.0 & $4.6 \pm 0.42(4.0-5.0)$ & - & $4.1 \pm 0.66(3.0-5.0)$ & $4.0 \pm 0.70(3.0-5.0)$ \\
\hline Posterior genital branch & 83 & $78.8 \pm 9.3(65-88)$ & - & $73.5 \pm 9.9(61-98)$ & $75.3 \pm 6.7(68-96)$ \\
\hline Vaginal length & 10.5 & $10.3 \pm 0.99(9.0-12)$ & - & $10.1 \pm 0.40(10-11)$ & $9.8 \pm 0.35(9.0-11)$ \\
\hline Vulva from anterior end & 182 & $175.4 \pm 12.0(152-189)$ & - & $157.1 \pm 9.5(135-176)$ & $164.2 \pm 10.0(146-188)$ \\
\hline Prerectum length & 41 & $39.3 \pm 3.7(32-43)$ & 61 & $31.9 \pm 5.0(27-43)$ & $33.6 \pm 5.3(27-46)$ \\
\hline Rectum length & 12 & $13.3 \pm 0.99(11.5-14.5)$ & 23.5 & $14.9 \pm 1.8(12.5-20.5)$ & $14.6 \pm 1.3(10-17)$ \\
\hline Tail length & 16.5 & $16.8 \pm 0.73(15-18)$ & 17.5 & $13.9 \pm 1.1(12-15)$ & $16.1 \pm 1.8(13-20)$ \\
\hline Spicules length & - & - & 20.5 & - & - \\
\hline Lateral guiding pieces & - & - & 5.5 & - & - \\
\hline Ventromedian supplements & - & - & 2 & - & - \\
\hline
\end{tabular}


sphincter. Uterus short and tubular, measuring 13-25 $\mu \mathrm{m}$. Anterior genital branch completely absent or rarely reduced to a very small sac, less than one-third midbody diameter long. Vagina cylindrical, extending inwards, 9.0-12.0 $\mu \mathrm{m}$ or about one-half to three-fifths (50-61\%) of midbody diameter; pars proximalis vaginae $5.5-8.0 \times 3.5-5.5 \mu \mathrm{m}$, encircled by circular muscles; pars distalis vaginae 3.0 $4.0 \mu \mathrm{m}$ with slightly curved walls; pars refringens absent. Vulva apparently a transverse slit. Prerectum 2.2-4.7 and rectum 0.9-1.5 times anal body diameter long. Tail convex-conoid to digitate with acute terminus, 1.1-1.7 times anal body diameter long, with a pair of caudal pores on each side.

\section{Male}

General morphology similar to that of female except for posterior region being more ventrally curved. Genital system diorchic, testes opposed, sperm cell spindle-shaped. In addition to adcloacal pair at $7 \mu \mathrm{m}$ from cloacal aperture, there are two irregularly spaced ventromedian supplements, first one located beyond the range of spicules, $19 \mu \mathrm{m}$ from adcloacal pair and second $15 \mu \mathrm{m}$ from first. Spicules typically dorylaimoid, curved ventrad, slightly robust, 5.3 times as long as wide and 1.2 times as long as cloacal body diameter, dorsal contour regularly convex, ventral contour bearing a moderately developed hump and hollow, curvature $129^{\circ}$, head occupying $13 \%$ of total spicules length, median pieces 12 times as long as wide or occupying 35\% of the spicules maximum width, reaching the spicules tip, posterior end $2 \mu \mathrm{m}$ wide. Lateral guiding pieces distinct, rod-like, about 5.5 times as long as wide or about one-fourth of the spicules length. Prerectum 3.7 and rectum 1.4 times cloacal body diameter long. Tail convex-conoid with acute terminus, about one cloacal body diameter long, with a pair of caudal pores on each side.

\section{Remarks}

In the presence of a short body and conoid tail with acute terminus, the new species comes close to B. caudatus Jairajpuri, 1966 and B. conicaudatus sp. nov. but, differs from the former in the absence of liplets (vs present); differently shaped amphids (stirrup-shaped vs cup-shaped); shorter odontostyle (7.5-9.5 vs $12 \mu \mathrm{m}$ ); odontophore longer than odontostyle (vs odontophore shorter than odontostyle, about one-half as long as odontostyle length) and presence of male (vs male absent).

From $B$. conicaudatus sp. nov., the new species differs in having a simple odontophore, without basal flanges (vs with distinct basal flanged); absence of anterior uterine sac (vs anterior uterine sac present); anterior vulva position ( $\mathrm{V}=41-48$ vs $55-58)$ and more ventromedian supplements (2 vs 1$)$.

In the presence of a conoid tail, the new species also comes close to B. lieberi Goseco et al., 1974 and B. westralis Siddiqi, 1970 but differs from the former in having shorter body ( $\mathrm{L}=0.31-0.44 \mathrm{vs}$ $0.67-0.90 \mathrm{~mm}$ ); female genital system mono-opisthodelphic (vs mono-prodelphic) and smaller spicules (20.5 vs $24-28 \mu \mathrm{m})$.

From $B$. westralis, the new species differs in having shorter body $(\mathrm{L}=0.31-0.44$ vs $0.55-0.75 \mathrm{~mm})$; female genital system mono-opisthodelphic (vs amphidelphic) and smaller spicules (20.5 vs 22-25 $\mu \mathrm{m}$ ).

$$
\begin{gathered}
\text { Basirotyleptus siddiqii sp. nov. } \\
\text { urn:1sid:zoobank.org:act:EA6FF0DE-F046-4879-B5C1-A0DC37394D25 } \\
\text { Figs 16-17, Table 11 }
\end{gathered}
$$

\section{Diagnosis}

Basirotyleptus siddiqii sp. nov. is characterized by having robust body, $0.36 \mathrm{~mm}$ long; lip region caplike, low, flat, offset by depression; lips rounded, inner part slightly elevated; odontostyle $7.5-8.0 \mu \mathrm{m}$ long, odontophore 10.0-10.5 $\mu \mathrm{m}$ long, total stylet length $17.5-18.5 \mu \mathrm{m}$; pharynx slender with slightly muscular anterior part, expanding gradually into a short pear-shaped basal bulb, occupying about 15- 
$16 \%$ of total neck length; female genital system monodelphic-opisthodelphic; anterior genital branch reduced to small sac, $4.0-6.0 \mu \mathrm{m}$ or one-fourth to one-third midbody diameter long, tail short, bluntly rounded, 0.9 times anal body diameter long.

\section{Etymology}

The new species is named after late Dr Mohammad Rafiq Siddiqi in recognition of his contribution to nematode taxonomy.

\section{Material examined}

\section{Holotype}

INDIA • O; Tamil Nadu State, Nilgiris hill district, Naduvattum; $1^{\circ} 28^{\prime} 37.8^{\prime \prime}$ N, 76 $32^{\prime} 36.7^{\prime \prime}$ E; $5-15 \mathrm{~cm}$ depth; 15 Nov. 2016; roots of shrubs (unidentified); slide reference number AMU/ZD/NC/Basirotyleptus siddiqii/1.

\section{Paratype}

INDIA • 1 क; same collection data as for holotype; slide reference number AMU/ZD/NC/Basirotyleptus siddiqii/2.

\section{Type habitat and locality}

Soil samples collected from around the roots of shrubs (unidentified) from Naduvattum, Nilgiris Hill, Tamil Nadu State.

\section{Description}

\section{Female}

Very small size, robust nematodes, curved ventrad or open C-shaped upon fixation; body cylindrical, tapering gradually towards both extremities but more so towards the anterior end. Cuticle with two distinct layers, $1.0 \mu \mathrm{m}$ thick at anterior region, $1.5 \mu \mathrm{m}$ at midbody and $2.0 \mu \mathrm{m}$ on tail. Outer cuticle thin, with fine transverse striations; inner layer thick, finely striated, loose, with radial refractive elements. Lateral chords occupying about $22-24 \%$ of midbody diameter. Lateral, dorsal and ventral body pores indistinct. Lip region cap-like, low, flat, offset by depression, 2.5 times as wide as high or about two-fifths of the body diameter at neck base. Lips rounded, amalgamated, inner part slightly elevated. Amphids stirrup-shaped, their aperture about two-thirds as wide as lip region diameter. Stoma a long, slender truncate cone, slightly sclerotized in the perioral region. Odontostyle short, slender, solid, needle-like, 1.0-1.1 times the lip region diameter long. Odontophore simple, sclerotized, with basal flanges, about 1.3 times the odontostyle length. Guiding ring simple, refractive, at 1.0-1.1 times the lip region diameter from anterior end. Pharynx consisting of a slender anterior part, expanding gradually into a short pearshaped basal bulb, with a perceptible thickening at the posterior part of its inner lining, occupying about $15-16 \%$ of total neck length. Nerve ring at $52-53 \%$ of neck length from anterior end. Cardia rounded to conoid, about one-fourth of the corresponding body diameter long.

Genital system monodelphic-opisthodelphic. Ovary reflexed, measuring $42-53 \mu \mathrm{m}$; oocytes arranged in single row except near tip. Oviduct joining the ovary subterminally, measuring 36-42 $\mu \mathrm{m}$, consisting of a slender distal portion and a well-developed pars dilatata. Oviduct-uterus junction marked by distinct sphincter. Uterus short and wide tubular, measuring 17-18 $\mu \mathrm{m}$. Anterior genital branch reduced to a small sac, $4.0-6.0 \mu \mathrm{m}$ or one-fourth to one third of midbody diameter. Sperms absent. Vagina cylindrical, extending inwards, $9.5 \mu \mathrm{m}$ or about one-half $(53 \%)$ of midbody diameter; pars proximalis vaginae 6.0 $6.5 \times 4.0-4.5 \mu \mathrm{m}$, encircled by circular muscles; pars distalis $3.5-4.0 \mu \mathrm{m}$ with slightly curved walls; pars refringens absent. Vulva apparently a transverse slit. Prerectum 6.0-6.8 and rectum 1.2-1.4 times anal body diameter long. Tail short, conoid, $0.8-0.9$ times anal body diameter long, with a pair of caudal pores on each side. 

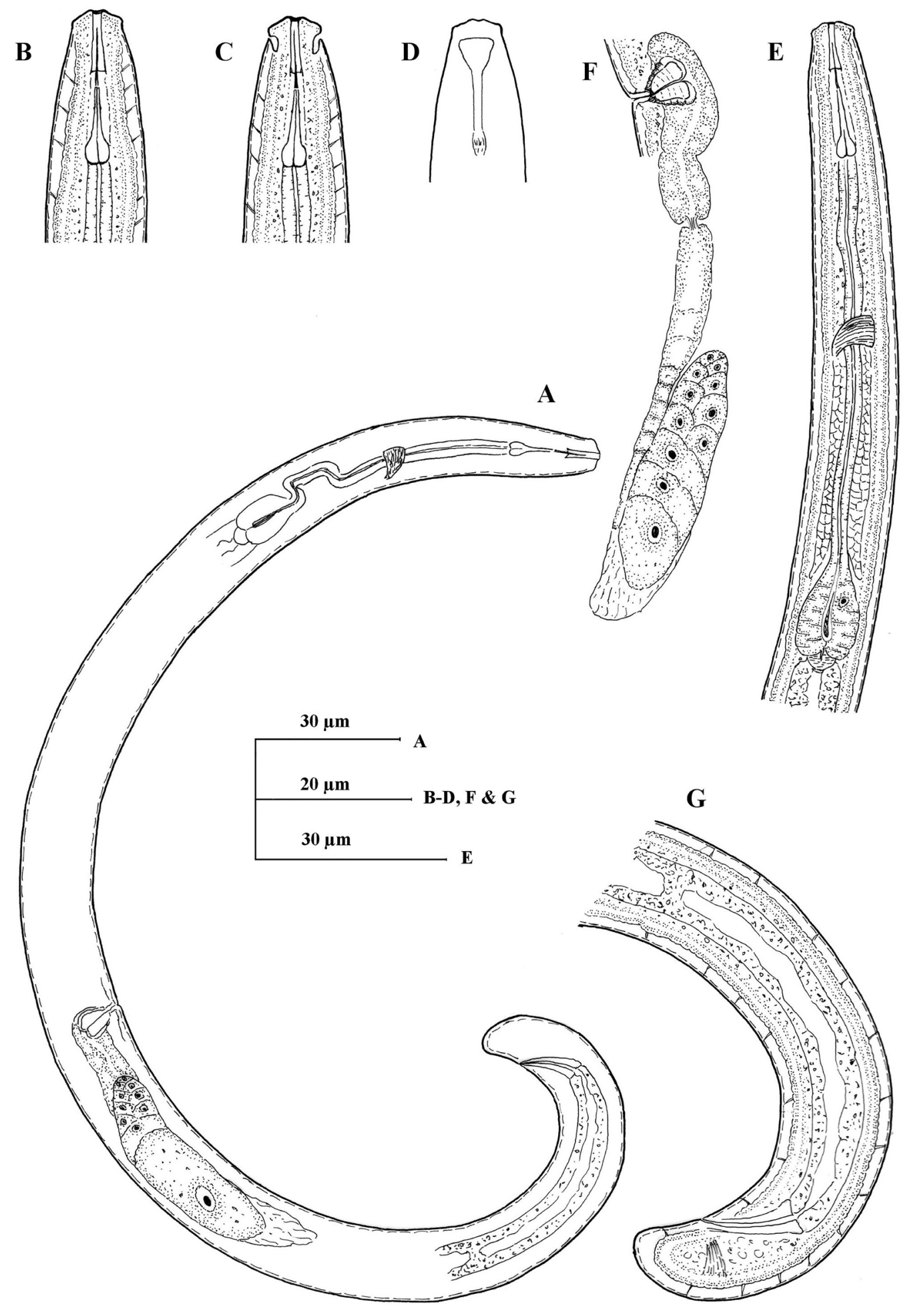

Fig. 16. Basirotyleptus siddiqii sp. nov., 9 . A-B, D-G. Holotype (AMU/ZD/NC/Basirotyleptus siddiqii/1). C. Paratype 1 (AMU/ZD/NC/Basirotyleptus siddiqii/2). A. Entire specimen. B-C. Anterior region. D. Anterior region showing amphid. E. Pharyngeal region. F. Genital system. G. Posterior region. 

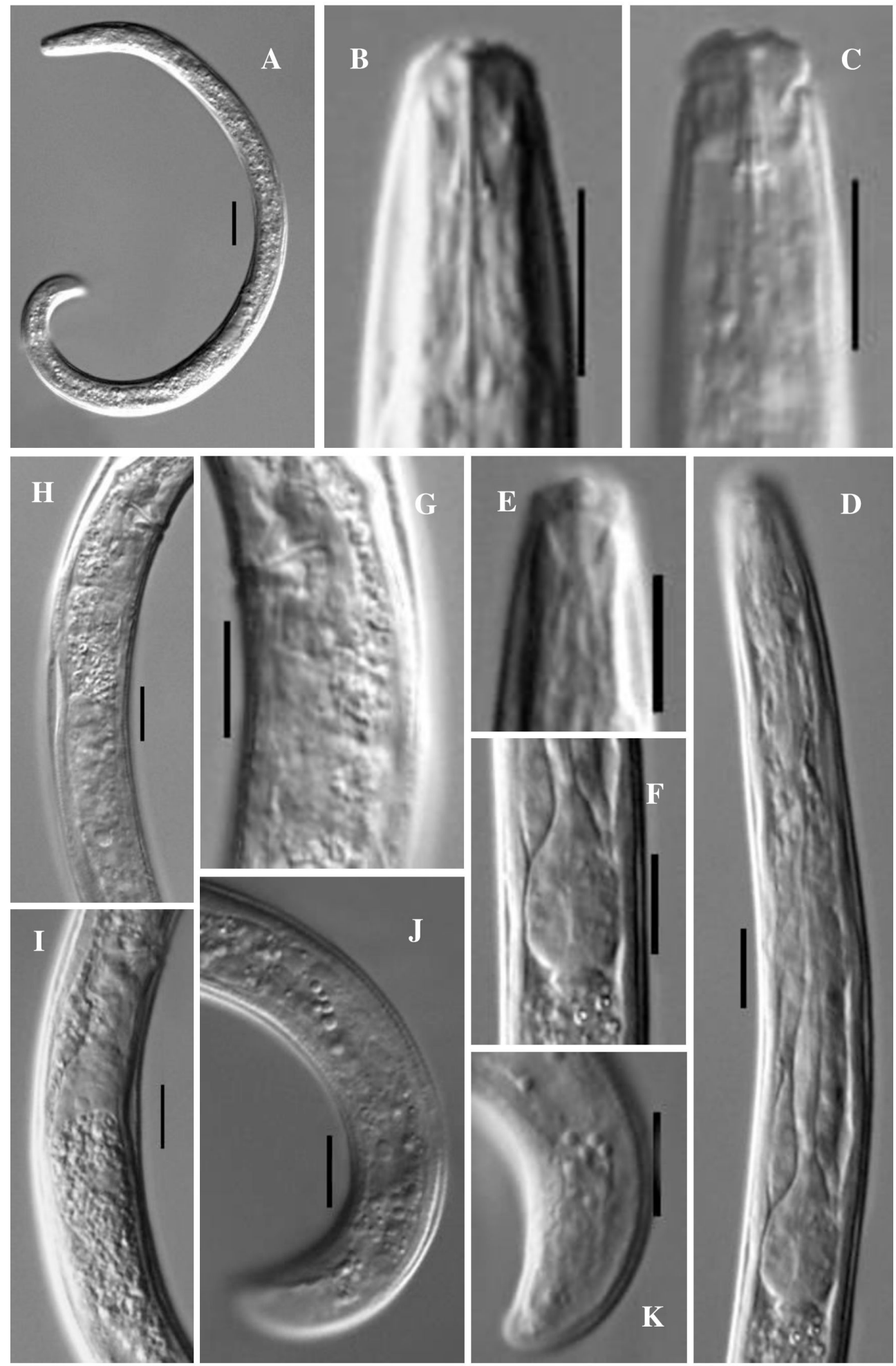

Fig. 17. Basirotyleptus siddiqii sp. nov., of (LM photographs). A-B, E, I-K. Holotype (AMU/ZD/ NC/Basirotyleptus siddiqii/1). C-D, F-H. Paratype 1 (AMU/ZD/NC/Basirotyleptus siddiqii/2). A. Entire specimen. B-C. Anterior region. D. Pharyngeal region. E. Anterior region showing amphid. F. Pharyngeal bulb. G. Vulval region. H-I. Genital system. J. Posterior region. K. Posterior end. Scale bars: $\mathrm{A}=20 \mu \mathrm{m} ; \mathrm{B}-\mathrm{K}=10 \mu \mathrm{m}$. 
Table 11. Measurements of Basirotyleptus siddiqii sp. nov. All measurements are in $\mu \mathrm{m}$.

\begin{tabular}{|c|c|c|}
\hline Characters & Holotype female & Paratype female \\
\hline $\mathrm{n}$ & & 1 \\
\hline $\mathrm{L}$ & 362 & 366 \\
\hline Body diameter at neck base & 16 & 16.5 \\
\hline Body diameter at mid body & 17.5 & 17 \\
\hline Body diameter at anus & 10 & 9.5 \\
\hline $\mathrm{a}$ & 20.1 & 21.5 \\
\hline $\mathrm{b}$ & 3.8 & 3.4 \\
\hline $\mathrm{c}$ & 40.2 & 40.7 \\
\hline$c^{\prime}$ & 0.9 & 0.9 \\
\hline $\mathrm{V}$ & 54.7 & 56.8 \\
\hline G1 & 1.1 & 1.6 \\
\hline $\mathrm{G} 2$ & 18.7 & 19.6 \\
\hline Lip region diameter & 7.5 & 7.5 \\
\hline Lip region height & 3.0 & 3.0 \\
\hline Amphidial aperture & 5.0 & - \\
\hline Odontostyle length & 7.5 & 8.0 \\
\hline Odontophore length & 10.0 & 10.5 \\
\hline Total stylet length & 17.5 & 18.5 \\
\hline Guiding ring from anterior end & 8.0 & 7.5 \\
\hline Nerve ring from anterior end & 50 & 55 \\
\hline Neck length & 95 & 106 \\
\hline Expanded part of pharynx & 15 & 16 \\
\hline Cardia length & 4.0 & 4.0 \\
\hline Anterior genital branch & 4.0 & 6.0 \\
\hline Posterior genital branch & 68 & 72 \\
\hline Vagina length & 9.5 & 9.0 \\
\hline Vulva from anterior end & 198 & 212 \\
\hline Prerectum length & 60 & 63 \\
\hline Rectum length & 12 & 13 \\
\hline Tail length & 9.0 & 9.0 \\
\hline
\end{tabular}


Male

Not found.

\section{Remarks}

In its small body size and flanged odontophore, the new species comes close to B. siremps Siddiqi, 1995; B. syncheilus Siddiqi, 1995 and B. minutus Siddiqi, 1995 but it differs from B. siremps in having low, flat lip region, offset by depression (vs lip region high, conoid, offset by constriction); cuticle finely striated (vs cuticle distinctly striated); slightly longer odontophore (10.0-10.5 vs 8.0-9.0 $\mu \mathrm{m}$ ); slightly posterior vulva position ( $\mathrm{V}=54-56$ vs $47-53$ ); in the shape and size of tail (conoid vs subcylindrical to a hemispherical terminus; $c^{\prime}=0.9$ vs $\left.1.2-1.7\right)$ and absence of male (vs male present).

From B. syncheilus, the new species differs in having lip region low, wider, offset by depression (vs lip region narrow, $5.0 \mu \mathrm{m}$, continuous with body); lips slightly raised (vs lips not raised); shorter odontostyle (7.5-8.0 vs 9.0-1.0); shorter pharyngeal bulb (15-16 vs $19 \mu \mathrm{m})$; shorter anterior uterine sac $(4.0-6.0 \mu \mathrm{m}$ or $0.2-0.3$ vs $18 \mu \mathrm{m}$ or about one midbody diameter) and absence of male (vs male present).

From B. minutus, the new species differs in having slightly short and slender body ( $\mathrm{L}=0.36$ vs 0.38 $0.51 \mathrm{~mm}$; $\mathrm{a}=20-21$ vs 23-39); amphids simple (vs duplex); shorter total stylet (17.5-18.5 vs $23-24 \mu \mathrm{m}$, odontostyle $7.5-8.0$ vs $10 \mu \mathrm{m}$, odontophore $10.0-10.5$ vs $13-14 \mu \mathrm{m})$, posterior vulva position $(\mathrm{V}=$ $54-56$ vs 32-42) and presence of anterior uterine sac (vs absent).

The new species also comes close to B. diminutus Siddiqi, 1995 but differs in having differently shaped lip region (lip region flat, low, offset by depression vs lip region conoid, high, offset by constriction); odontophore with distinctly basal flanges (vs poorly basal flanges), posterior vulva position ( $\mathrm{V}=54-56$ vs 37-42) and presence of anterior uterine sac (vs absent).

Key to species of the genus Basirotyleptus (modified after Goseco et al. 1974)

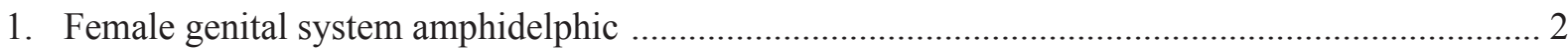

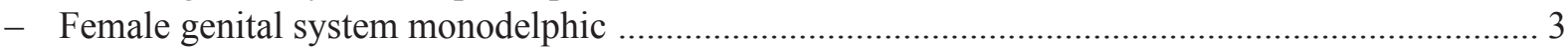

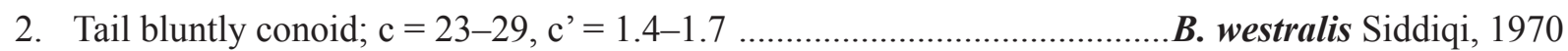

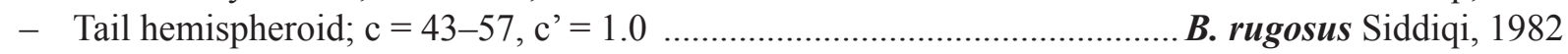

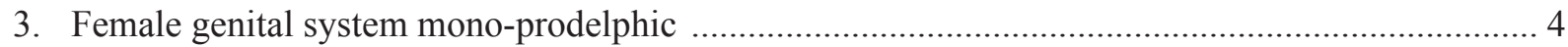

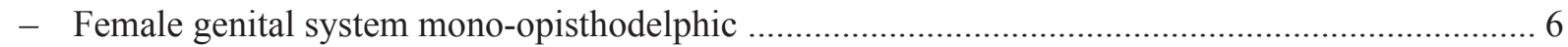

4. Body length more than $0.6 \mathrm{~mm}$; spicules longer, $24-28 \mu \mathrm{m}$............... B. lieberi Goseco et al., 1970

- Body length less than $0.6 \mathrm{~mm}$; spicules shorter, $15-21 \mu \mathrm{m}$...................................................... 5

5. Odontophore with basal flanges; post-uterine sac long, 1.8-3.5 times midbody diameter long; tail comparatively long, conoid, 18-28 $\mu \mathrm{m}$

B. heynsi Furstenberg, 1980

- Odontophore without basal flanges; post-uterine sac short, 1.2 times midbody diameter long; tail short, conoid, $15 \mu \mathrm{m}$ B. eximius Siddiqi \& Khan, 1964

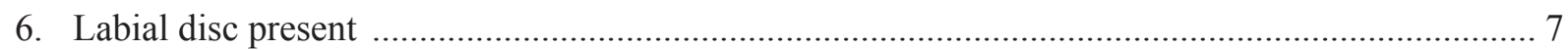

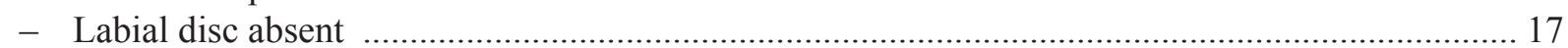

7. Odontophore with basal flanges

B. constrictus sp. nov.

- Odontophore without basal flanges 8 
8. Anterior uterine sac absent

B. ethiopicus Siddiqi, 1970

- Anterior uterine sac present

9. Anterior uterine $\mathrm{sac}<15 \mu \mathrm{m}$ or less than one midbody diameter long ...................................... 10

- Anterior uterine sac $>15 \mu \mathrm{m}$ or more than one midbody diameter long ...................................... 12

10. Body $0.41-0.57 \mathrm{~mm}$ long; $\mathrm{b}=3.8-4.2$

B. nemoralis Siddiqi, 1970

- Body more than $6.0 \mathrm{~mm}$ long; $\mathrm{b}=4.3-5.8$

11. $\mathrm{c}=74-100$; prerectum $48 \mu \mathrm{m}$ or about 3.0 times anal body diameter

B. coronatus Siddiqi \& Khan, 1965

- $\quad \mathrm{c}=<69$; prerectum $73-104 \mu \mathrm{m}$ or $4.0-5.4$ times anal body diameter

B. indicus Dhanam \& Jairajpuri, 1999

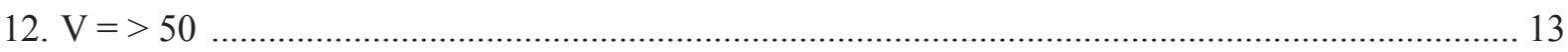

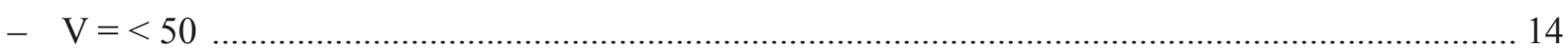

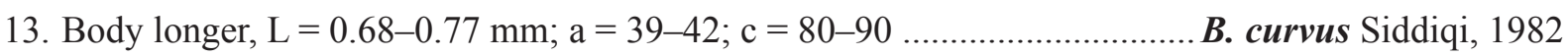

- Body shorter, $\mathrm{L}=0.45 \mathrm{~mm} ; \mathrm{a}=28 ; \mathrm{c}=35$.............................................. discinus Siddiqi, 1995

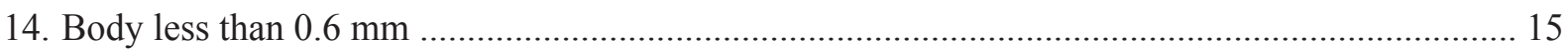

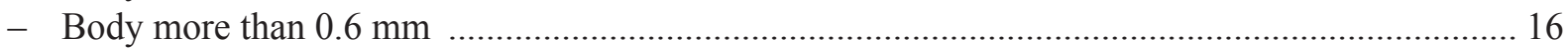

15. Pharynx short, $90 \mu \mathrm{m}, \mathrm{b}=4.7-6.0 ; \mathrm{V}=36-43 ; \mathrm{c}=42-44$.......B. modestus Hussain \& Khan, 1968

- Pharynx long, $110-124 \mu \mathrm{m}, \mathrm{b}=3.8-4.9 ; \mathrm{V}=42-47 ; \mathrm{c}=47-67$.................... safiae Siddiqi, 1997

16. Odontostyle $6.0 \mu \mathrm{m}$, odonotophore $10.5-11 \mu \mathrm{m}$; spicules $24 \mu \mathrm{m}$............. B. barbarae Siddiqi, 1997

- Odontostyle 7.5-8.5 $\mu \mathrm{m}$, odonotophore 12-15 $\mu \mathrm{m}$; spicules $29-32 \mu \mathrm{m}$.... B. robustus Siddiqi, 1982

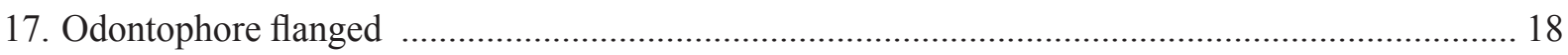

- Odontophore simple, with sclerotized or slightly swollen base, not flanged ................................. 25

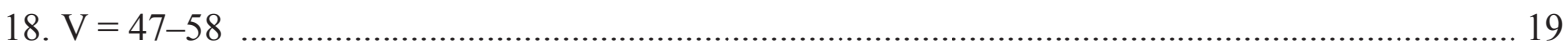

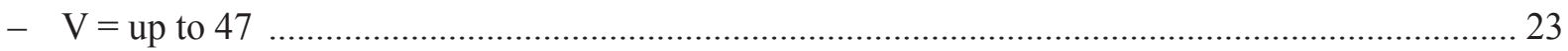

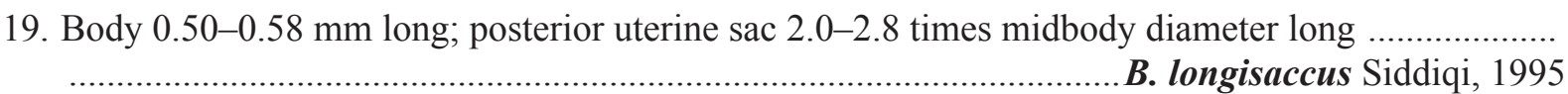

- Body 0.30-0.51 mm long; posterior uterine sac about as long as midbody diameter long ............ 20

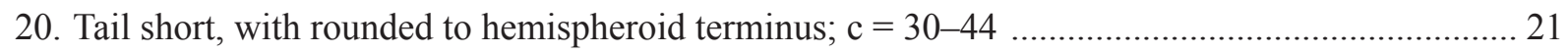

- Tail short, conoid with acute terminus; c $<28$........................................ B. conicuadatus sp. nov.

21. Odontostyle 9.0-10 $\mu \mathrm{m}$; neck length 110-119 $\mu \mathrm{m}$................................. s. syncheillus Siddiqi, 1995

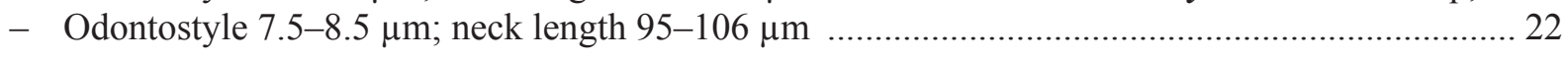

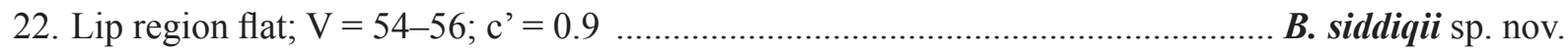

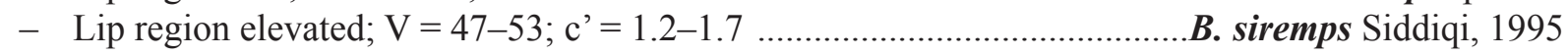

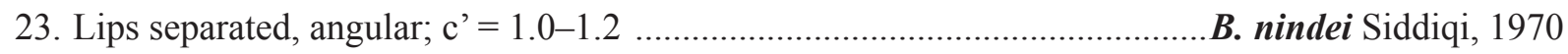

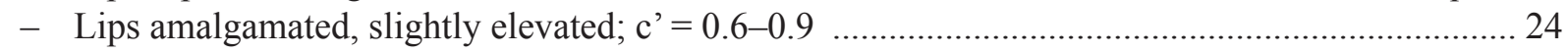


24. Longer body, $\mathrm{L}=0.38-0.48 \mathrm{~mm}$; amphids duplex; odontostyle $10-14 \mu \mathrm{m}$

- Shorter body, $\mathrm{L}=0.29-0.36 \mathrm{~mm}$; amphids simple; odontostyle 7.5-8.5 $\mu \mathrm{m}$

25. Anterior uterine sac absent

- Anterior uterine sac present

26. Tail conoid to digitate, with acute terminus; $c^{\prime}=1.1-1.7$

- Tail rounded to hemispheroid; $\mathrm{c}^{\prime}=<1.0$

27. Liplets distinct; amphids cup-shaped; odontophore about one-half of odontostyle length

B. caudatus Jairajpuri, 1966

- Liplets absent; amphids stirrup-shaped; odontophore about 1.2-1.5 times odontostyle length

B. neocaudatus sp. nov.

28. $\mathrm{V}=31-41$; tail rounded, with terminal caudal pore

B. acus Goseco et al., 1974

- $\mathrm{V}=47-48$; tail conoid, without terminal caudal pore B. soueastus Ahmad \& Jairajpuri, 1979

29. Vulva posterior, $\mathrm{V}=>50$ B. penetrans (Thorne, 1964) Siddiqi, 1969

- Vulva anterior, $\mathrm{V}=<44$

30. Body long, 0.68-0.98 mm; pharyngeal bulb 20-26 $\mu \mathrm{m}$

- Body short, 0.45-0.68 mm; pharyngeal bulb 14-20 $\mu \mathrm{m}$

31. Cuticle without punctations; amphids stirrup-shaped

B. upicus Ahmad \& Jairajpuri, 1979

- Cuticle bearing punctations; amphids cup-shaped

32. Amphids duplex, cup-shaped; anterior uterine sac $24.5-46 \mu \mathrm{m}$; males absent

B. goaensis sp. nov.

- Amphids simple, cup-shaped, anterior uterine sac $65 \mu \mathrm{m}$; males present

B. rotundicaudatus (Khan, 1987) Andrássy, 2009

33. Anterior uterine sac more than one midbody diameter long

- Anterior uterine sac less than one midbody diameter long

34. Odontostyle $10-14 \mu \mathrm{m}$; tail 11-16 $\mu \mathrm{m}$

B. basiri Jairajpuri, 1964

- Odontostyle 6.0-7.0 $\mu \mathrm{m}$; tail 8.0-10 $\mu \mathrm{m}$ B. minimus Jana \& Baqri, 1981

35. Lip region distinctly offset; odontostyle, $11-15 \mu \mathrm{m}$

B. pini Siddiqi \& Khan, 1965

- Lip region distinctly not offset; odontostyle, $4.6 \mu \mathrm{m}$ B. striatus (Thorne, 1964) Siddiqi, 1969

\section{Discussion}

Basirotyleptus is a taxon of soil-inhabiting nematodes, mostly occurring in undisturbed natural soils, and due to the presence of delicate odontostyle, it is considered as fungal feeders (Yeates 2007). The genus Basirotyleptus is quite heterogenous, and has a worldwide distribution, with representatives reported from all continents (except Antarctica). It is one of the most speciose taxon in the superfamily Tylencholaimoidea of the order Dorylaimida (Table 12), but is not yet well studied from the Western Ghats. A total of 12 species ( $38 \%$ of the total described species) has been recorded from India so far, 


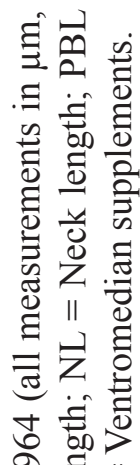

앙

$\exists \pm \sum^{\infty}$

뉵

密

ㄴ.

डे

:

Q

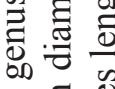

$\stackrel{0.0}{\circ}$

$\stackrel{0}{\circ}$

की तथ

.

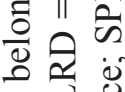

\%

尊.

की

.0.

छี.

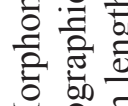

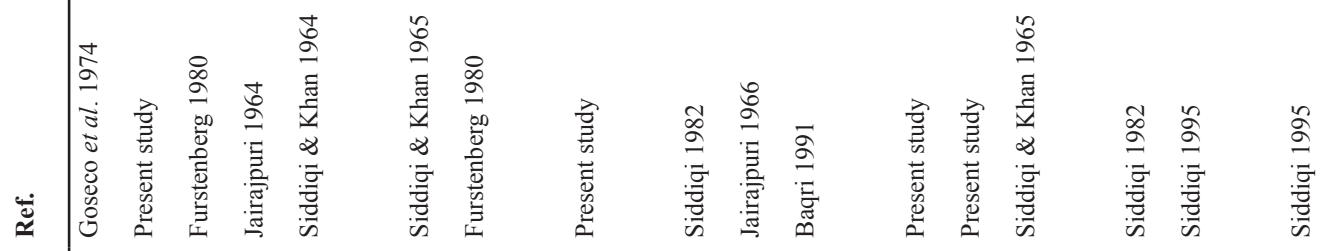

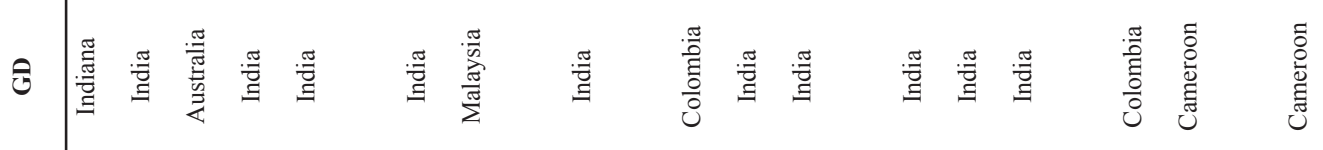




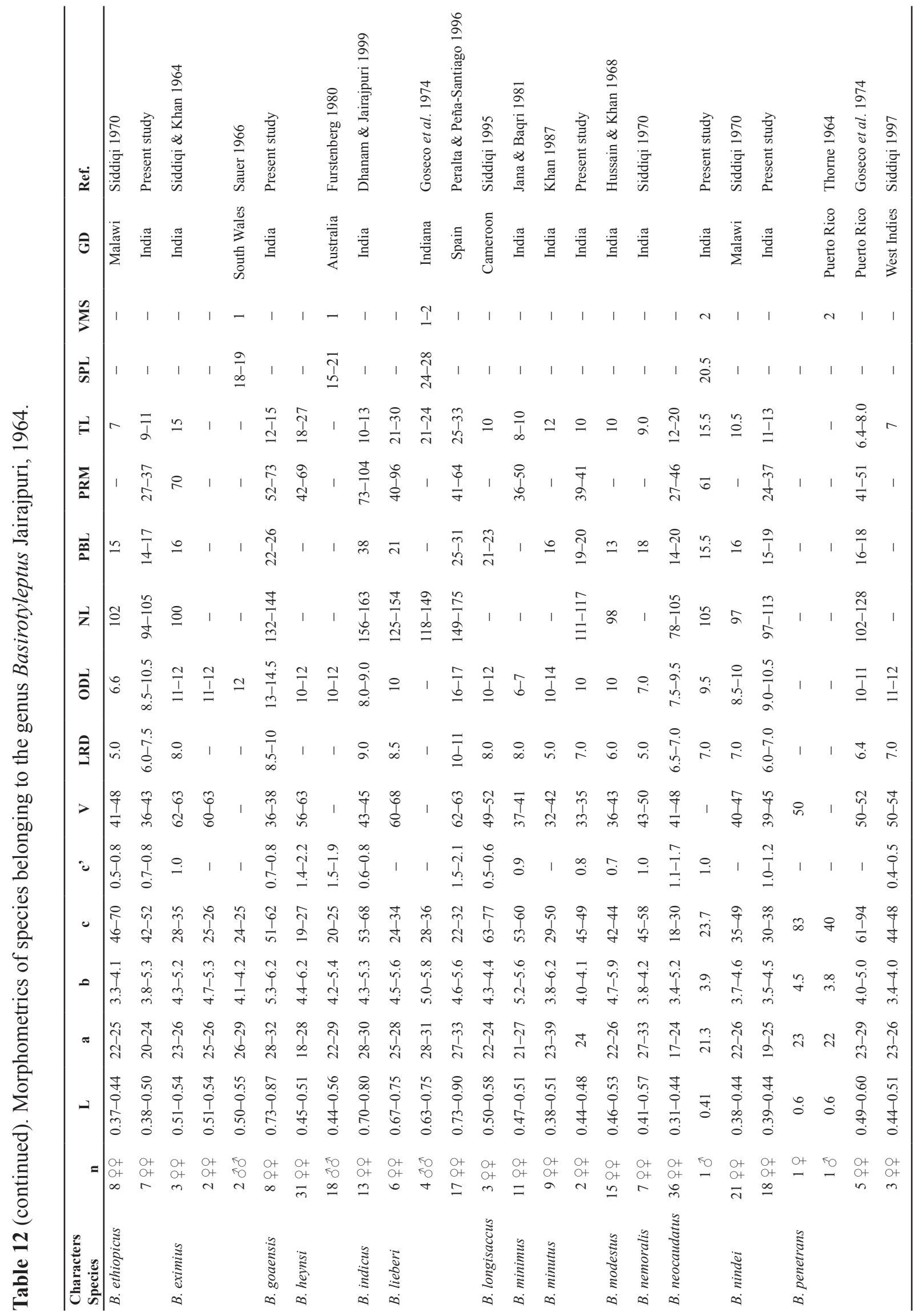




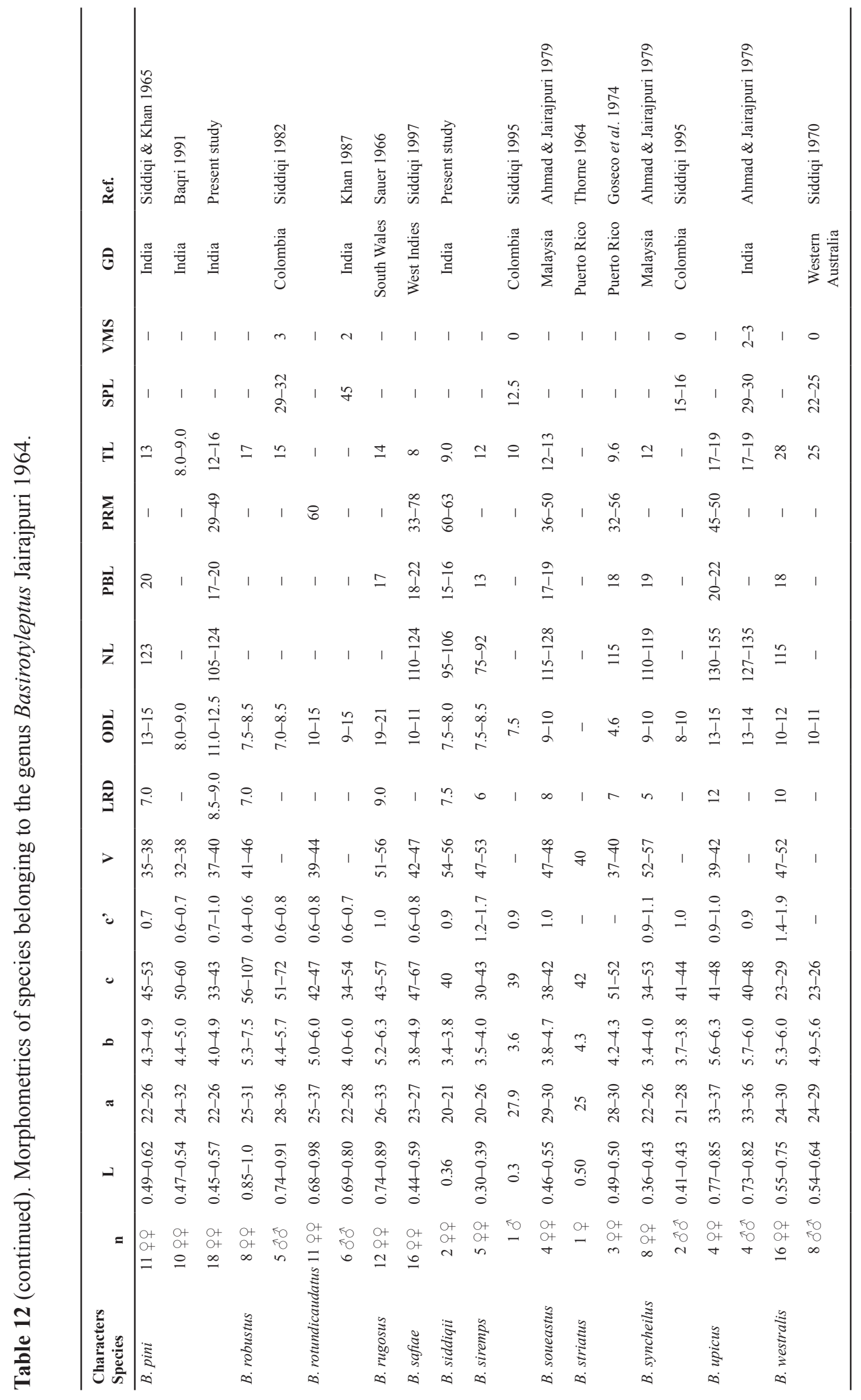


and only three of them (B. rotundicaudatus Khan, 1987, B. minutus Khan, 1987 and B. indicus Dhanam \& Jairajpuri, 1999) from this biodiversity hotspot. In the ongoing study, 18 populations representing the genus Basirotyleptus were collected from different localities in the Western Ghats, India. Based on a detailed taxonomic study, they were found to represent eleven species, six known and five new, making a total of 36 valid species under the genus Basirotyleptus. As a result of this survey, the Western Ghats fauna is now represented by 13 species of the genus Basirotyleptus, which constitutes about $68 \%$ of Indian's Basirotyleptus fauna and 36\% of the World's Basirotyleptus fauna. Three species (B. acus, B. ethiopicus and B. nindei) were recorded here for the first time from India.

\section{Acknowledgements}

The first author thanks the University Grants Commission for a UGC-Non-Net Fellowship. The authors are also thankful to the DST-PURSE programme for financial assistance and the Chairman, Department of Zoology, Aligarh Muslim University for providing laboratory facilities.

\section{References}

Ahmad M. \& Jairajpuri M.S. 1979. Four new species of Leptonchidae (Nematoda: Dorylaimida). Indian Journal of Nematology 9: 125-135.

Andrássy I. 2009. Free-living nematodes of Hungary (Nematoda errantia). Vol. III. Pedozoologica Hungarica 5. Hungarian Natural History Museum, Budapest, Hungary.

Baqri Q.H. 1991. Contribution to the fauna of Sikkim. Nematodes associated with citrus from Sikkim, India. Records of the Zoological Survey of India, Occassional Paper 128: 1-103.

Cobb N.A. 1918. Estimating the nema population of the soil. United States Department of Agriculture, Bureau of Plant Industry, Agriculture Technical Circular 1: 1-48.

de Maeseneer J. \& d'Herde J. 1963. Méthodes utilisées pour l'étude des anguillules libres du sol. Revue de Agriculture Bureaux 16: 441-447.

Dhanam M. \& Jairajpuri M.S. 1999. New leptonchid nematodes: one new genus and eleven new species from Malnad tracts of Karnataka, India. International Journal of Nematology 9: 205-209.

Furstenberg J.P. 1980. A new species and some new records of Basirotyleptus (Nematoda: Dorylaimida: (Belonchinae) from Australia and Malaysia. Nematologica 26: 149-156.

https://doi.org/10.1163/187529280X00035

Goseco C.G., Ferris V.R. \& Ferris J.M. 1974. Revision in Leptonchoidea (Nematoda: Dorylaimida). Tyleptus in Leptonchidae, Tyleptinae; Basirotyleptus in Leptonchidae, Belonenchinae and Loncharionema n. gen. in Leptonchidae, Xiphinemellinae. Research Bulletin, Purdue University Agriculture Experimental Station 913: 1-24.

Husain S.I. \& Khan A.M. 1968. Basirotyleptus modestus n. sp. and two new species of Dorylaimoides Thorne \& Swanger, 1936 from India. Nematologica 14: 362-368.

https://doi.org/10.1163/187529268X00039

Jairajpuri M.S. 1964. Studies on Campydoridae and Leptonchidae (Nematode: Dorylaimoidea) with description of Basirotyleptus basiri n. gen., n. sp. from India. Proceedings of the Helminthological Society of Washington 31: 59-64.

Jairajpuri M.S. 1966. On Basirotyleptus caudatus n. sp. and a redescription of Thornenema thienemanni (Schneider, 1937) Andrássy, 1959 (Nematoda: Dorylaimoidea). Proceedings of the Helminthological Society of Washington 33: 30-33. 
Jairajpuri M.S. \& Ahmad W. 1992. Dorylaimida. Free-Living, Predaceous and Plant-Parasitic Nematodes. E.J. Brill, Leiden, The Netherlands \& Oxford \& IBH, New Delhi.

Jana A. \& Baqri Q.H. 1981. Nematodes from West Bengal (India) XI. Studies on the species of the superfamily Leptonchoidea (Dorylaimida). Journal of Zoological Society of India 33: 1-24.

Khan E. 1987. Punctoleptus rotundicaudatus gen. n., sp. n. and Basirotyleptus minutus sp. n. (Nematoda: Leptonchoidea) from India. Indian Journal of Nematology 16: 175-179.

LiY., Baniyamuddin M., Ahmad W. \& Wu J. 2008. Four new and four known species of Tylencholaimoidea (Dorylaimida: Nematoda) from China. Journal of Natural History 42: 1991-2010.

https://doi.org/10.1080/00222930802254722

Peña-Santiago R. 2006. Dorylaimida Part I: Superfamilies Belondiroidea, Nygolaimoidea and Tylencholaimoidea. In: Abebe E., Traunspurger W. \& Andrássy I. (eds) Freshwater Nematodes: Ecology and Taxonomy: 326-391. CAB International. Wallingford, UK.

https://doi.org/10.1079/9780851990095.0326

Peralta M. \& Peña-Santiago R. 1996. Nematodes of the order Dorylaimida from Andalucia Oriental, Spain. The families Leptonchidae Thome, 1935 and Aulolaimoididae Jairajpuri, 1964. Fundamental and Applied Nematology 19: 481-497.

Sauer M.R. 1966. A new species of Basirotyleptus and the male of B. eximus (Siddiqi \& Khan, 1964) Siddiqi \& Khan, 1965. Nematologica 12: 215-218. https://doi.org/10.1163/187529266X00626

Seinhorst J.W. 1959. A rapid method for the transfer of nematodes from fixative to anhydrous glycerine. Nematologica 15: 81-100. https://doi.org/10.1163/187529259X00381

Shamim S., Nasira K. \& Shahina F. 2014. Fresh water nematodes from Sindh, Pakistan. International Journal of Biology and Biotechnology 11: 497-504.

Siddiqi M.R. 1969. Crateronema n. gen. (Crateronematidae n. fam.), Poronemella n. gen. (Lodellonematinae n. subfam.), and Chrysonemoides n. gen. (Chrysonematidae n. fam.) with a revised classification of Dorylaimoidea (Nematoda). Nematologica 15: 81-100.

https://doi.org/10.1163/187529269X00128

Siddiqi M.R. 1970. Five new species of Basirotyleptus and the description of Leptonchus baccatus n. sp. (Nematoda: Dorylaimoidea). Nematologica 16: 203-212. https://doi.org/10.1163/187529270X00216

Siddiqi M.R. 1982. Seven new genera of dorylaimoid nematodes from Colombian rain forest. Systematic Parasitology 4: 69-87. https://doi.org/10.1007/BF00012230

Siddiqi M.R. 1983. Three new species of Aculonchus gen. n. and Zetalaimus blepheronchus gen. n. sp. n. (Dorylaimida: Belonenchinae). Indian Journal of Nematology 12: 312-319.

Siddiqi M.R. 1995. Nematodes of tropical rainforests, 5. Seven new genera and forty two new species of dorylaims. Afro-Asian Journal of Nematology 5: 72-109.

Siddiqi M.R. 1997. Basirotyleptus safiae sp. n., B. penetrans (Thorne) and Actinolaimoides attenuatus sp. n. (Nematoda: Dorylaimida) from Guadeloupe, French West Indies. International Journal of Nematology 7: 132-136.

Siddiqi M.R. \& Khan S.H. 1964. Trichonchium n. g. (Nematoda: Campydoridae), with descriptions of two new species from tea soil, Assam, India. Nematologica 9: 641-645.

https://doi.org/10.1163/187529263X00755

Siddiqi M.R. \& Khan E. 1965. A review of the nematode genus Basirotyleptus (Dorylaimida) with descriptions of two new species. Proceedings of the Helminthological Society of Washington 32: 23-31. 
Thorne G. 1964. Nematodes of Puerto Rico: Belondiroidea, new superfamily, Leptonchidae Thorne, 1935, and Belonenchidae new family (Nematoda, Adenophorea, Dorylaimida). University of Puerto Rico Agricultural Experiment Station, Technical Papers 39: 1-51.

Yeates G.W.2007. Abundance, diversity, and resilience of nematode assemblages in forest soils. Canadian Journal of Forest Research 37: 216-225. https://doi.org/10.1139/x06-172

Manuscript received: 15 September 2021

Manuscript accepted: 25 October 2021

Published on: 7 February 2022

Topic editor: Tony Robillard

Desk editor: Pepe Fernández

Printed versions of all papers are also deposited in the libraries of the institutes that are members of the EJT consortium: Muséum national d'histoire naturelle, Paris, France; Meise Botanic Garden, Belgium; Royal Museum for Central Africa, Tervuren, Belgium; Royal Belgian Institute of Natural Sciences, Brussels, Belgium; Natural History Museum of Denmark, Copenhagen, Denmark; Naturalis Biodiversity Center, Leiden, the Netherlands; Museo Nacional de Ciencias Naturales-CSIC, Madrid, Spain; Real Jardín Botánico de Madrid CSIC, Spain; Zoological Research Museum Alexander Koenig, Bonn, Germany; National Museum, Prague, Czech Republic. 